\title{
Just a Phase? \\ Assessment of the Potential for Phase \\ Change Materials in New Zealand Buildings
}

Master of Architecture Thesis Submission

September 2010

by

Alice Harland

Victoria University of Wellington 


\section{Abstract}

Phase change materials in buildings could save energy and cost by bridging the gap between when energy is available and when it is needed. This is because they are capable of storing and releasing large amounts of energy by melting and solidifying at an appropriate temperature for use in buildings. Yet, despite being in development for decades, PCM building materials have not achieved significant market penetration.

This thesis investigates ways in which Phase Change Materials have been used in buildings in the past and what products are currently available. The investigation suggests that because of cost these materials might be appropriately applied to commercial interiors. It explores the history of office design internationally and in New Zealand and suggests alternative ways in which PCM materials could be used that would be attractive to designers and architects. By assessing the results of two modelling studies this research is able to suggest at what cost these products may become viable.

The thesis concludes that market penetration unlikely to change significantly unless one or more of the following occur;

- A significantly cheaper, and sustainable, PCM is found

- Domestic electricity prices rise so dramatically that the potential $20 \%$ space heating saving accruing from PCMs becomes far more significant

- A level of design value is added to the development of PCM products in order to attract a wider market

In the making of low energy and sustainable buildings it has been recognised that a multi-disciplinary approach is vital for a successful outcome, and it would seem logical that same would be true of developing new products towards the goal of sustainability. Designers and engineers must work collaboratively to create desirable products and accurate and validated information about their performance in buildings is needed for architects to persuade clients to use new materials and take the lead in the process of achieving majority acceptance.

Despite previous international research, these studies show that in New Zealand PCM application has more benefit in residential applications than in the commercial sector. 


\section{Table of Contents}

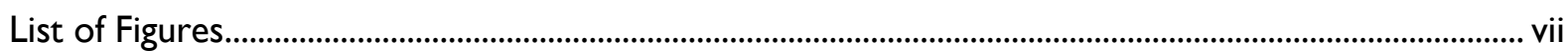

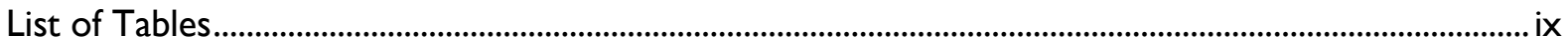

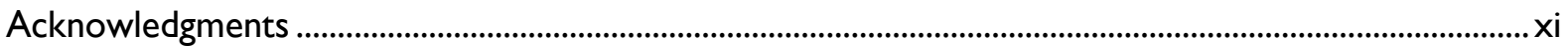

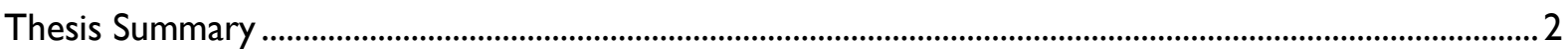

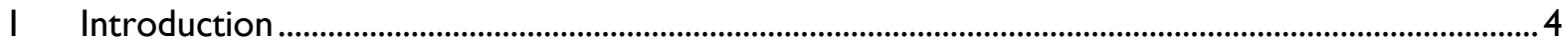

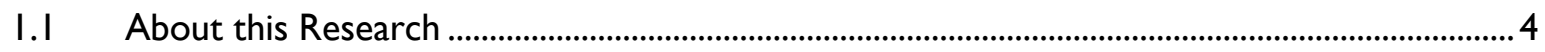

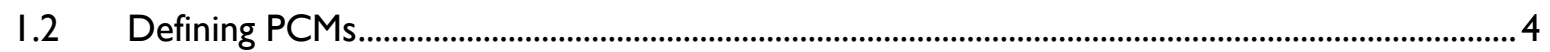

I.3 Historic Use

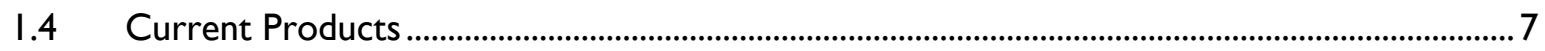

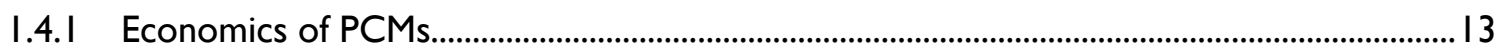

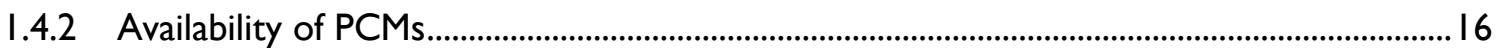

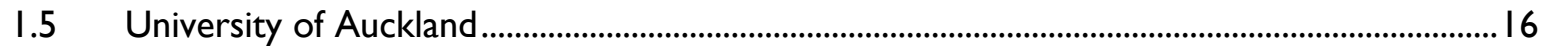

I.6 Commercial and Residential Buildings............................................................................... 17

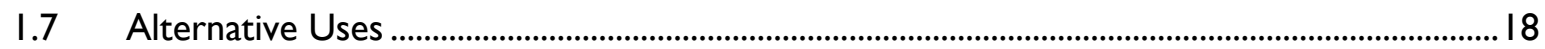

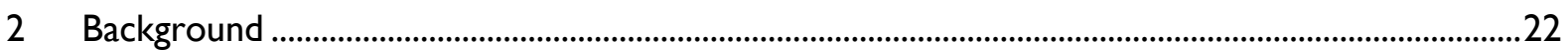

2.I Energy Efficiency, Peak Oil and Solar Gain............................................................................22

2.2 Sustainable Development, Sustainability and Sustainable Design ..............................................24

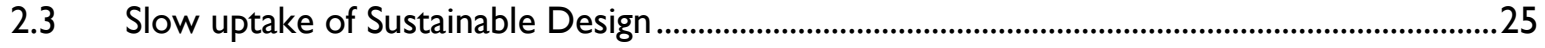

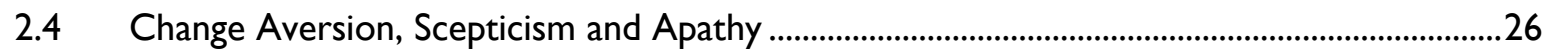

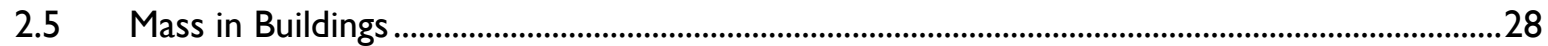

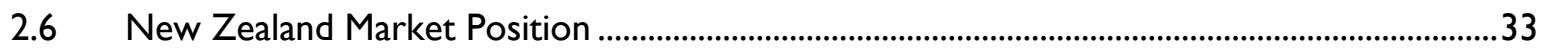

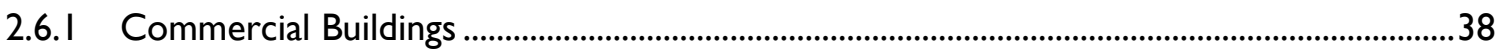

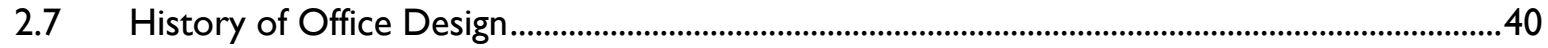

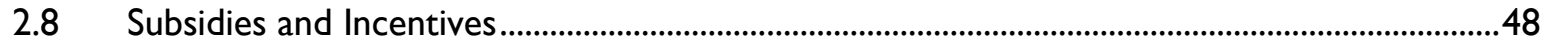

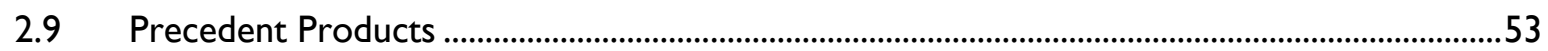

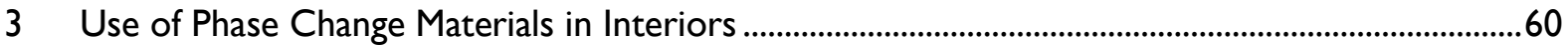

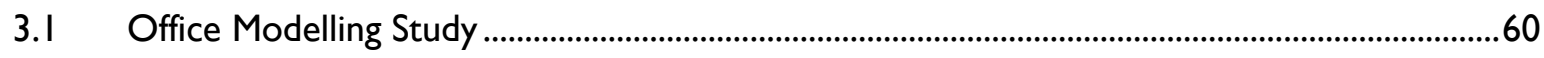

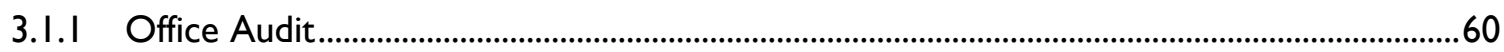




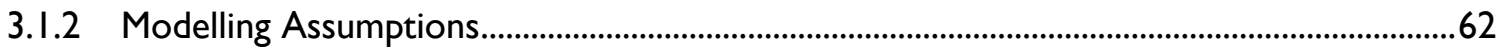

3.I.3 Construction and Materials .............................................................................................65

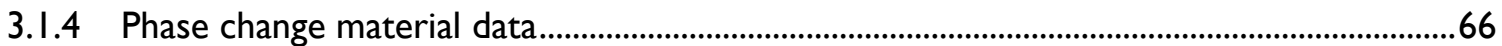

3.1.5 Modelling Methodology ………………………..........................................................................66

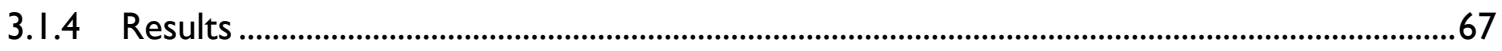

3.2 Residential Modelling Study - University of Auckland .............................................................

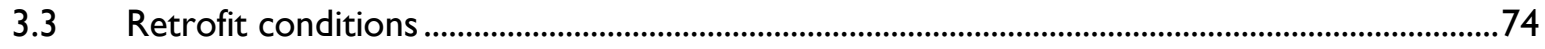

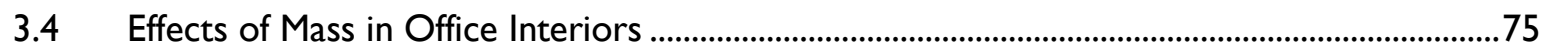

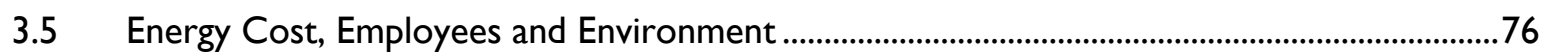

3.6 Revolutionising or Redesigning ...........................................................................................76

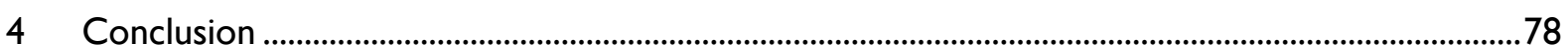

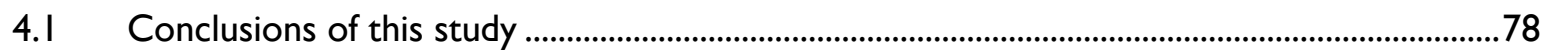

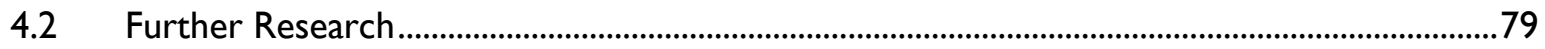

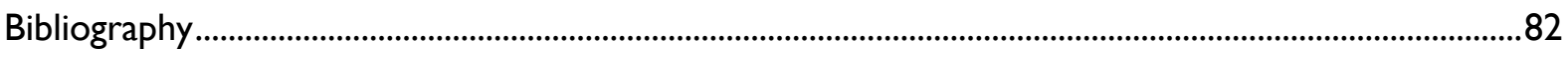

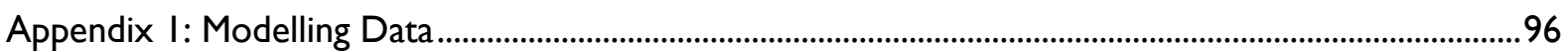

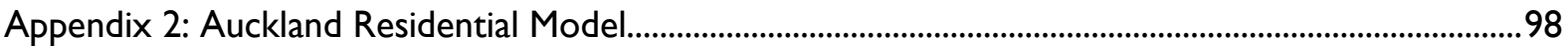

Appendix 3: ALF Report .................................................................................................................. 104

Appendix 4: Data from Portland Cement Association Report ........................................................... II0 


\section{List of Figures}

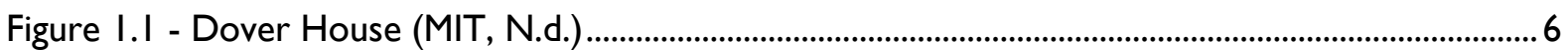

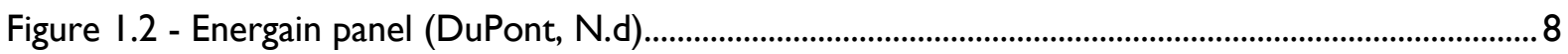

Figure I.3 - Micronal $囚$ PCM detail (Wellert, 2004) ................................................................................. 9

Figure I.4 - Delta-Cool 24 products (Cosella-Dorken, 2009) ………………….......................................

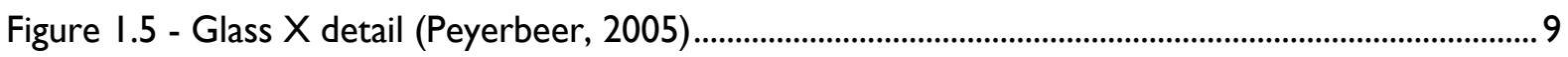

Figure I.6 - Sonnenschiff positive energy commercial building with visible PV roofs, and unseen PCMs (Vale, 2007)

Figure I.7 - The 3-Litre House detail (Schubert, N.d)

Figure 2.I - Effect of insulated mass on Hockerton Houses during a cold week (Energy Saving Trust, 2003)

Figure 2.2 - Sections through two basements with Badgir, one linked to the Qanat introducing additional coolth (Roaf, 2009) .30

Figure 2.3 - Typical Chinese village built on Feng Shui principles (Vale, Personal Communication, 2010)

Figure 2.4 - Direct solar gain (Donn \& Thomas, 200I).

Figure 2.5 - Indirect solar gain (Donn \& Thomas, 200I)

Figure 2.6 - The Larkin Building, Buffalo, New York, 1904 (Duffy, 1997, p. 20).

Figure 2.7 - Cellular perimeter office design, The Plaza On K, Washington, DC (Transwestern, 2008)

Figure 2.8 - Open-plan office design, levels 14 and I5 Mighty River power (Inside Limited, 2007) ....42

Figure 2.9 - NMB, Amsterdam. Purpose built, low energy, high mass, Northern European office building (www.tonyparr.nl/)

Figure 2.10 - CRT Monitors in use; no screens to disguise cables (Duffy F. , 1997, p. 10). 
Figure 2.II - CRT Monitors in use with screens (Duffy F., 1997, p. 184).

Figure 2.12 - Corner desk with LCD monitor (Formway Furniture Limited, N.d.)

Figure 2.13 - Straight desk with LCD monitors (Aspect Furniture Limited, 2010) . .46

Figure 2.14 - Duffy's diagram of organisational types (Duffy F., 1997) . .48

Figure 2.15 - New Zealand electricity prices . .59

Figure 3.I - Rectangular floor plan variations showing base, walls and screening partitions, respectively.

Figure 3.2 - Square floor plan variations showing, base, walls and screening partitions, respectively.63

Figure 3.3 - Model building section 64

Figure 3.4 - Energy reduction in rectangular building simulation 5\% PCM content

Figure 3.5 - Energy reduction in square building simulation 5\% PCM content. .69

Figure 3.6 - Energy reduction comparison 5\% and 30\% PCM content . .69

Figure 3.7 - Energy use reduction for construction variations .70

Figure 3.8 - Generic house plan . .71

Figure 3.9 - PCM energy reduction by content - heating and cooling by $\mathrm{kWh} / \mathrm{m}^{2} /$ year . .72

Figure 3.10 - PCM energy use reduction by content - heating only by percentage. . .73 


\section{List of Tables}

Table I- Characteristics of basic PCM materials available

Table 2 - PCMs in realised projects

Table I.3 - Soybean oil biodiesel production costs and subsidies, 2004-2006 (2002 Dollars per Gallon) (Radich, 2004)

Table I.4 - Yellow grease biodiesel production costs and subsidies, 2004-2006 (2002 Dollars per

Gallon) (Radich, 2004)

Table I.5 - Projected production costs for diesel fuel by feedstock, 2004-20I 3 (2002 Dollars per

Gallon) (Radich, 2004)

Table 2.I - Personal computer energy use (Bluejay, 2010)

Table 2.2 - Renewable energy source grants available in New Zealand

Table 2.3 - Breakdown of PV module and system costs (2008 \$US per kWP) for various PV module costs and different applications (IT Power (Australia) Pty Ltd, 2009)

Table 2.4 - World incentives for renewable energy programmes

Table 2.5 - New Zealand electricity prices (nominal) (Ministry of Economic Development, 2008) ....58

Table 3.I - Wellington office audit.

Table 3.2 - Construction and materials for typical office

Table 3.3 - PCM variations

Table 3.4 - Construction variations

Table 3.5 - Original construction type, baseline and PCM variation 6

Table 3.6 - Construction and materials for typical house (See Appendix 2: Auckland Residential Model)

Table 3.7 - Model parameters (See Appendix 2: Auckland Residential Model) .72 


\section{Acknowledgments}

Professor Mohammed Farid at the University of Auckland

for providing the funding to enable me to do this research

Sam Behzadi and Laurent Rusch at the University of Auckland

for providing the data for chapter 3.2 and answering my many questions

Jessica Bennett

for her commitment and help well beyond her initial modelling study in summer 2009

Christina MacKay

for her support and valued input, and without whom I would not have embarked on this journey

Brenda Vale

for her support, motivation, generosity of knowledge and amazing editing skills, without whom I don't believe I could have completed the journey

Sean Andersen,

my husband and the love of my life, for his patience and support and generally making everything better 


\section{Thesis Summary}

Introduction

This chapter explains the nature of PCMs and why they might be used in buildings. It looks at the products available on the market at the time this thesis was written. It goes on to investigate the economics of using PCM materials based on paraffin waxes and on alternatives, such as plant derived fatty acids. The chapter concludes with a discussion of the use of PCM products in various buildings and the results. It also looks at current research at the University of Auckland and the way PCM materials may be used in other products.

\section{Background}

This chapter explores the drivers that support PCM innovations and the impediments to those innovations. It looks at the market position in New Zealand and globally, and how PCMs might fit into this market. It discusses the history of office design and how PCMs could fit into the office environment, and investigates how precedent products have achieved market penetration and what subsidy support those innovations have been given to aid them in gaining market momentum.

Use of Phase change materials in Interiors

This chapter discusses the outcomes of two modelling studies conducted to assess the effect of PCMs in interior environments based on their use in currently available wallboard products. The first is a study of commercial office buildings conducted by Jessica Bennett as a summer research project in conjunction with the writing of this thesis. The second is a modelling study of a residential house in Auckland conducted by the Department of Materials and Chemicals Engineering at the University of Auckland. The chapter presents, assesses and compares the results. It further discusses the possibility for PCM wall boards in retrofit conditions and possible alternatives to these to achieve similar financial and energy savings.

\section{Conclusion}

Based on the assessment of existing products and installations of PCM products, as well as the outcomes of the two modelling studies, this chapter makes an assessment of the potential for Phase Change Materials in New Zealand buildings, and makes recommendations for future research. 


\section{Introduction}

\section{I.I About this Research}

The University of Auckland commissioned this thesis to look at ways in which Phase Change materials (PCMs) (see chapter I.2) have been used in buildings and to suggest possible alternative ways in which these materials could be used that would be attractive to designers and architects. This work has entailed an investigation to discover what PCM materials are currently on the market and to find existing buildings which have used PCMs. This information has not been easy to discover, which may explain why designers are not rushing to use these materials (see chapterl.3).

The research has looked at the ways PCMs are used in buildings and the benefits that can be gained. It has also examined the costs of the products, including future costs from current research into PCMs that are not based on petroleum. Another aim of the research was to link these findings to two modelling studies of PCMs in buildings. One was a study undertaken by Jessica Bennett as a summer scholarship study at Victoria University into the use of PCM products in office interiors (see chapter 3.1), based on earlier work in this thesis on identifying what a typical office interior is (see chapter 2.7). The second modelling study that was reviewed in this research of a house in Auckland was undertaken at the Department of Mechanical and Materials Engineering at the University of Auckland (see chapter 3.2).

The research thus addresses the following questions

I. How have PCMs been used in buildings and why?

2. Why has the uptake of PCM technology been slow in the building industry?

3. What might encourage designers and architects to make more use of PCMs in buildings?

This research has attempted to draw the answers to these questions and the other disparate threads of the investigations together to the point where recommendations can be made about the future for the use of PCMs in buildings, particularly in office interior fit-outs (see chapter 4.1).

\subsection{Defining PCMs}

Phase change materials are substances with a high heat of fusion. PCMs use the energy stored in chemical bonds and their endothermic and exothermic reactions using the latent heat of fusion, this means they are capable of storing and releasing large amounts of energy by melting and solidifying at a given temperature. This storage of heat has the potential to be exploited for a number of uses. The thermal energy transfer occurs when materials change state, or phase, from liquid to solid, or solid 
to liquid (Vavan Vuceljic, 2009). In buildings PCMs could bridge the gap between when energy is available and when it is needed. The only other material that does this in a building is mass, so PCMs can be viewed as a thin version of "mass". For use in an interior environment PCMs with a melting temperature of between 19 and 24 degrees are needed, as this temperature range is close to human comfort level (Rohles, 2007). The PCM must be able to cycle continuously though changes of state without loss of its attributes. By their nature PCMs have low conductivity which restricts the functional depth of the material to approximately $10 \mathrm{~mm}$ from the exposed surface. If both sides of a PCM material are exposed to an environment the depth may be doubled (Farid M. , 2009).

To be used in buildings the PCM chemicals, often paraffin waxes, need to be incorporated in some form of material. In fact the wax must be contained, either by micro encapsulation or encapsulation at a larger scale, to prevent loss in mass through evaporation (Farid M. , 2009). Specific paraffin waxes match the necessary temperature range well but due to their expense and origin in nonsustainable petrochemicals (Sustainable Energy Forum, 2006) other PCMs are being explored, such as fatty acids, as these can come from other sources, such as waste animal products. Current construction industry based developments largely use paraffin based PCMs encapsulated at the micro level and impregnated into other materials such as gypsum board. These products are potentially well suited for residential applications in New Zealand, due to the high winter sunshine hours (Mackintosh, 200I), the wide use of light weight timber framed buildings in the residential sector and the ability of PCMs to replace mass as a passive heat store (see chapter 2.5).

\section{I.3 Historic Use}

The first documented use of a PCM as a form of passive heating was by Dr Maria Telkes, the "Sun Queen", in 1948. The Hungarian born, American scientist had been fascinated by the possibilities of solar heating since the 1920s. Unable to convince a tertiary institution of these, Telkes collaborated with sculptor Amelia Peabody, the client, who personally funded the project, and architect Eleanor Raymond (Kubiszewski, 2006). The House in Dover, Massachusetts contained approximately $4 \mathrm{~m}^{3}$ of Glauber's salts, an early PCM material. The Glauber's salts were placed in drums housed in spaces between the main rooms that were ventilated with fans to move the warm air into the living space in winter. In summer the same system delivered cool air to the rooms. This system alone could keep the house warm for approximately II sunless days. Unfortunately the life cycle of Glauber's salts meant they stopped working in the third winter and conventional heating needed to be installed. A realist, Telkes is reputed to have said "Who can expect the first of its kind to be 100 percent effective?" and indeed, 60 years later this form of heating has yet to be perfected. In 195I Telkes wrote "Sunlight will be used as a source of energy sooner or later anyway. Why wait?" (ISES, 1976) 


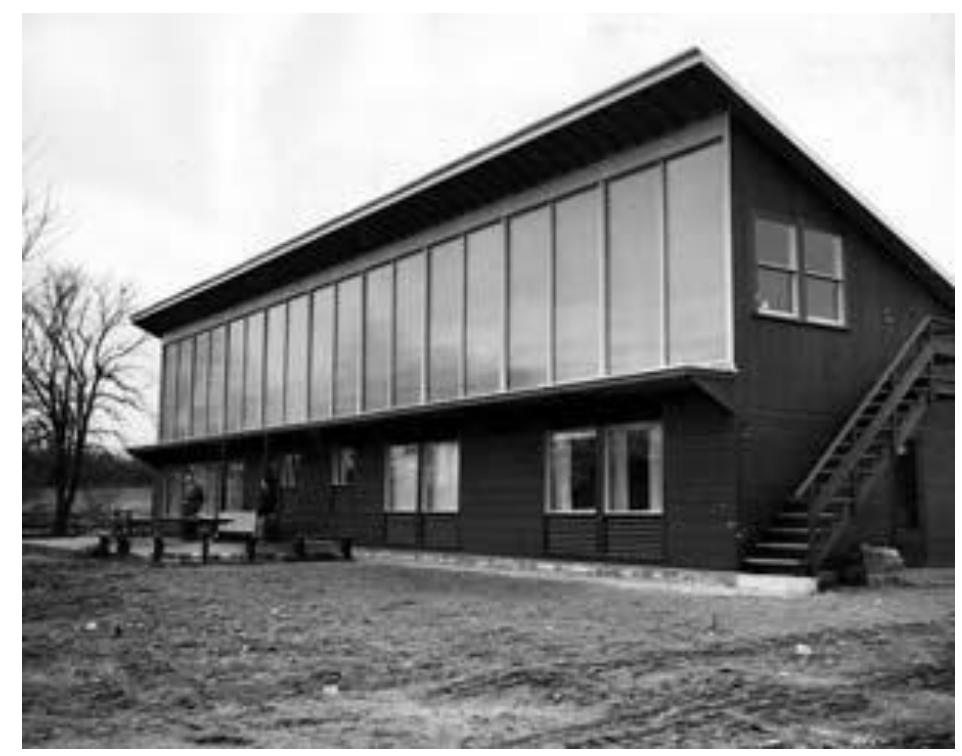

Figure I.I - Dover House (MIT, N.d.)

Since 1948, more resources have been invested in the development of PCMs which have been extensively studied over decades, notably in the 1990s by Peippo (Peippo, Kauranen, \& Lund, 199/a) (Peippo, Kauranen, \& Lund, 199/b). Yet, despite their virtues being discovered and the difficulties of designing a PCM with appropriate melt temperatures and infinite melt cycles being resolved (www.epsltd.co.uk/, 2009) (Peippo, Kauranen, \& Lund, 199la), the momentum for their application in buildings has been slow to build and even Peippo seems to have lost faith. He gave PCMs no mention in his 1998 article about optimising design options for low energy solar buildings (Peippo 1998). The assumption could be drawn that the cost for benefit was simply too high for PCMs to be a design option at that time.

In New Zealand only one project that has included a PCM product has been found during this research. This is the NZi3 (National ICT Innovation Institute) building at the University of Canterbury which houses a centre for research into information and communication technology, a function which can lead to increased heat load through the extensive use of computing facilities. Though this building was awarded an innovation point in its Green Star assessment (see chapter 2.7) for the inclusion of SmartBoard $\AA$, a commercial PCM material (see chapter I.4 below), in its ceiling panels (Barbour, 2009), neither NZi3's dedicated website (NZi3, 2009) nor the Green Star website (Green Star New Zealand, 2009), both of which list many virtues of the building, mention the inclusion of the PCM product. In fact the only energy features of NZi3 given on the home web site are the use of natural daylight and ventilation, double glazing to almost all windows and external shading on the east and west elevations (University of Canterbury, 2009). No mention is made of mass or PCMs in this building although the use of mass internal walls to reduce internal peak temperatures is mentioned on the same website in association with the University of Canterbury's 
new Health Centre. To seek out more information about the use of PCMs in NZi3 the building was visited on the school of engineering's open day in July 2010, but unfortunately no-one was available in the building with any knowledge of the installation of the SmartBoard $@$, let alone any performance data from its use. This is a real problem for PCMs as most designers will only use innovative products where the benefits of doing so are clear, as designers are the people who have to persuade clients to pay for these innovations.

\section{I.4 Current Products}

There are many varieties of PCM available on the market today in their two most common basic forms of paraffin waxes or salts. These materials have a wide range of melt temperatures and thus provide a large range of options for building materials, a selection of the largest suppliers within the temperature range that might be considered for architectural application $\left(19-30^{\circ} \mathrm{C}\right)$ are shown here in Table I- Characteristics of basic PCM materials available below.

\begin{tabular}{|c|c|c|c|c|}
\hline Manufacturer & Product & $\begin{array}{c}\text { Melting } \\
\text { point } \\
{\left[{ }^{\circ} \mathrm{C}\right]}\end{array}$ & 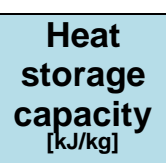 & Type \\
\hline PlusICE & S19 & 19 & 160 & Salt Hydrate \\
\hline Rubitherm & RT 21 & 21 & 134 & Latent Heat Paraffin \\
\hline BASF & DS 5030 & 21 & 51 & Paraffin Dispersion \\
\hline BASF & DS 5029 & 21 & 125 & Paraffin Powder \\
\hline Rubitherm & SP 22 A17 & 22 & 150 & Latent heat blend (Paraffin \& Salt hydrate) \\
\hline PlusICE & $\mathrm{S} 21$ & 22 & 170 & Salt Hydrate \\
\hline PlusICE & $\mathrm{A} 22$ & 22 & 145 & Organic \\
\hline PlusICE & $\mathrm{S} 23$ & 23 & 175 & Salt Hydrate \\
\hline PlusICE & A23 & 23 & 145 & Organic \\
\hline BASF & DS 5007 & 23 & 55 & Paraffin Dispersion \\
\hline BASF & DS 5008 & 23 & 135 & Paraffin Powder \\
\hline PlusICE & A24 & 24 & 145 & Organic \\
\hline Rubitherm & SP 25 A8 & 25 & 180 & Latent heat blend (Paraffin \& Salt hydrate) \\
\hline PlusICE & $\mathrm{S} 25$ & 25 & 180 & Salt Hydrate \\
\hline PlusiCE & A25 & 25 & 150 & Organic \\
\hline PlusICE & A26 & 26 & 150 & Organic \\
\hline BASF & DS 5000 & 26 & 59 & Paraffin Dispersion \\
\hline BASF & DS 5001 & 26 & 145 & Paraffin Powder \\
\hline Rubitherm & RT 27 & 27 & 179 & Latent Heat Paraffin \\
\hline PlusICE & $S 27$ & 27 & 183 & Salt Hydrate \\
\hline PlusICE & A28 & 28 & 155 & Organic \\
\hline Rubitherm & SP 29 A15 & 29 & 157 & Latent heat blend (Paraffin \& Salt hydrate) \\
\hline PlusICE & S30 & 30 & 190 & Salt Hydrate \\
\hline
\end{tabular}

Table I- Characteristics of basic PCM materials available 
However, there are only seven options that appear to have been developed into market-ready building products (although some have multiple melt point options, meaning that they use more than one of the basic paraffins or salts). These products, introduced below are Energain, SmartBoard $®$, Delta Cool 24, Glass X, Clima 26, CelBloc Plus and Ilkatherm chilled ceiling panels.

SmartBoard $\AA$, Clima 26, CelBloc Plus and Ilkatherm chilled ceiling panels use Micronal $\AA$ PCM developed by BASF in conjunction with the Fraunhofer Institute. Micronal囚 PCM comes in dispersion (for use in liquids) or powder form in three melt temperatures, $21^{\circ} \mathrm{C}, 23^{\circ} \mathrm{C}$ and $26^{\circ} \mathrm{C}$. Micronal ${ }^{\circledR}$ PCM was developed with support funding from the BMWi (Federal Ministry of Economic and Technology) (BASF, 2008). All Micronal $($ products have been tested over 10,000 cycles, simulating 30 years of continuous use (BASF, 2009).

Energain from DuPont is a board material of PCM sandwiched between two layers of aluminium for application behind dry wall board (Du Pont, 2010).

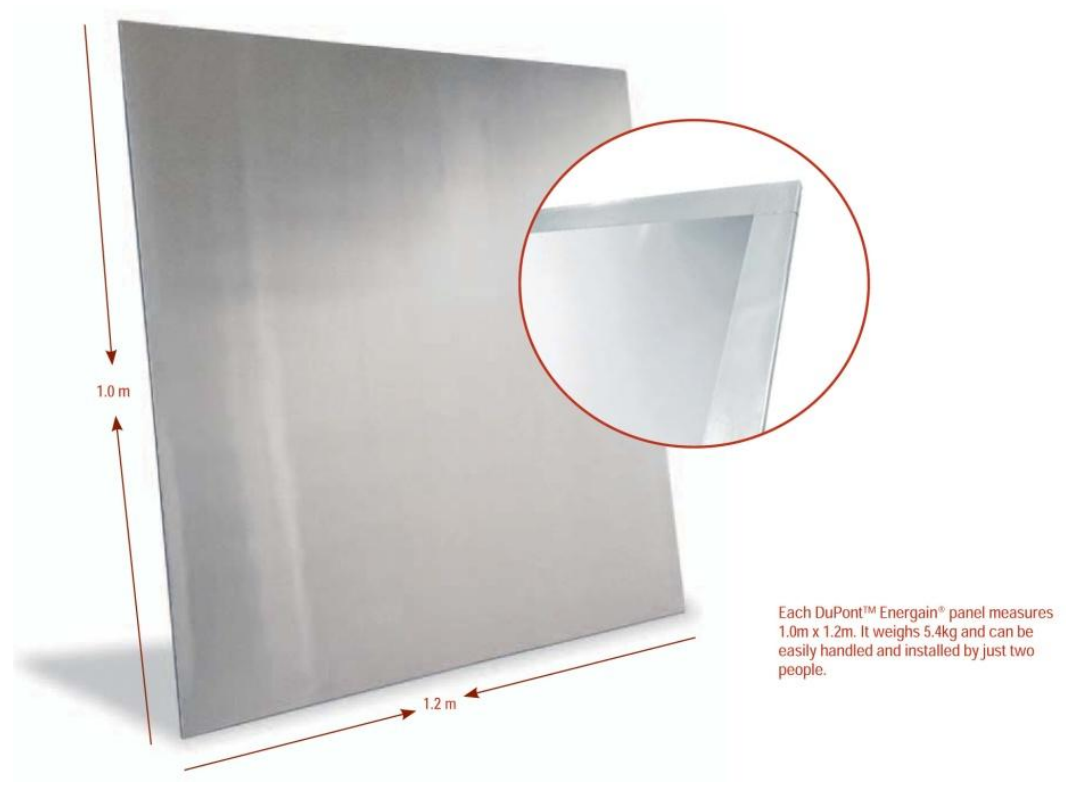

Figure I.2 - Energain panel (DuPont, N.d)

SmartBoard $\circledast$ from BASF, marketed by Knauf, is a dry-line gypsum based board impregnated with BASF's Micronal $\circledast$ $\circledast$ PCM, of paraffin droplets micro encapsulated in a non-formaldehyde capsule (Knauf, 2009). SmartBoard $\AA$ was removed from the market in 2010. 


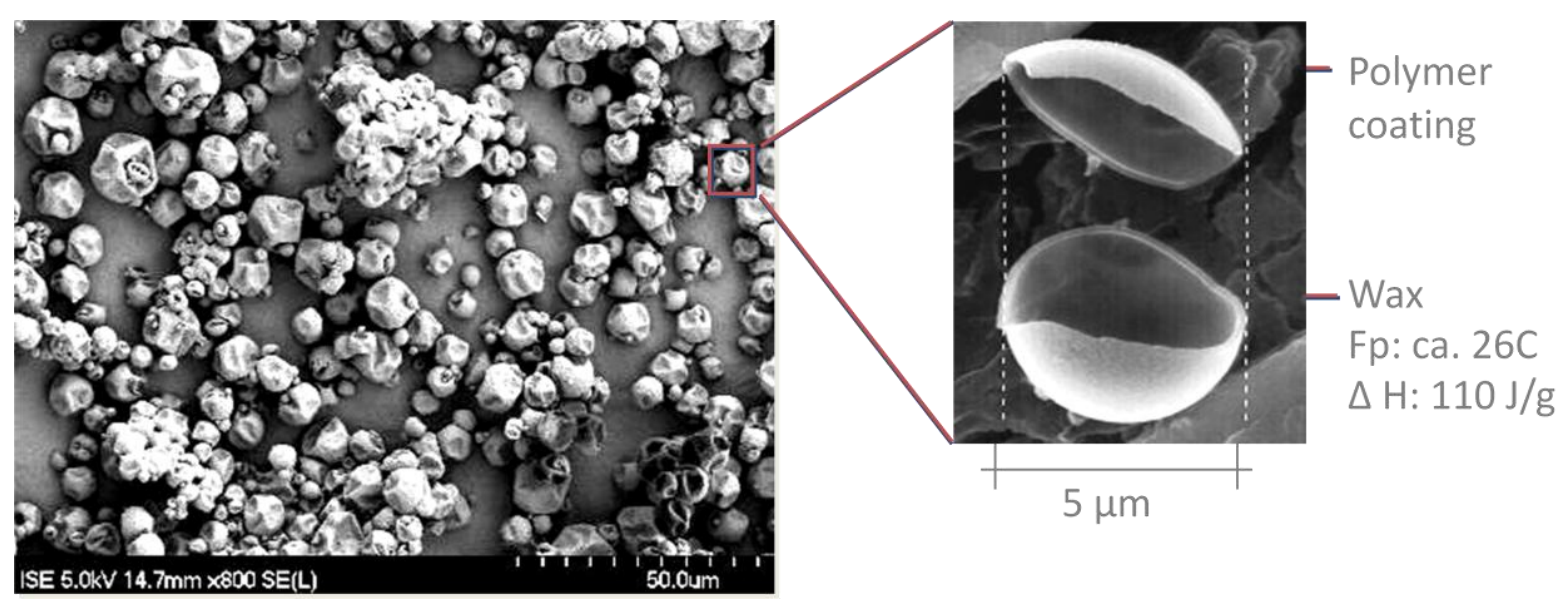

Figure I.3 - Micronal® PCM detail (Wellert, 2004)

Delta-Cool 24 by Dörken is a packaged PCM suited to retrofit situations, above ceilings, under floors etc (Cosella-Dorken, 2010).

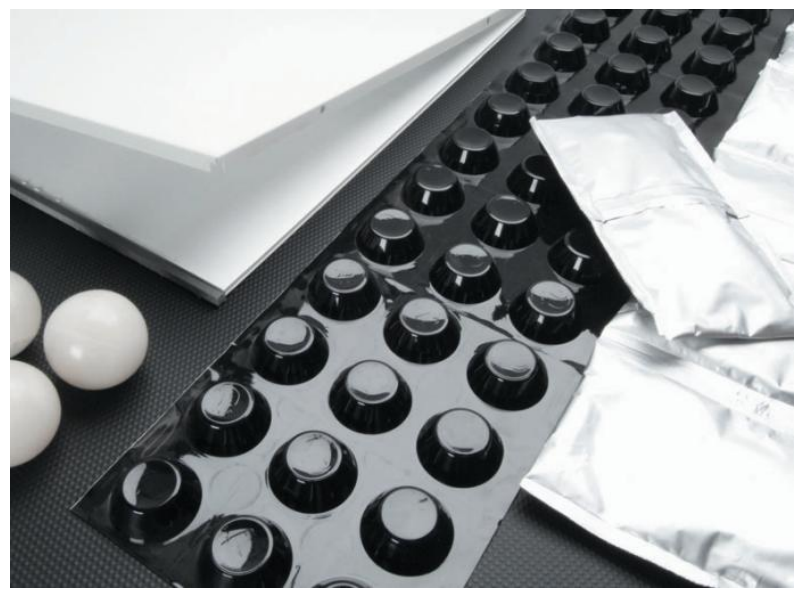

Figure I.4 - Delta-Cool 24 products (Cosella-Dorken, 2009)

Glass $X$ by Peyerbeer is an aluminium framed window element for installation in the facade with the ability to filter solar gain to seasonal requirements based on the angle of the sun (Peyerbeer, 2005).

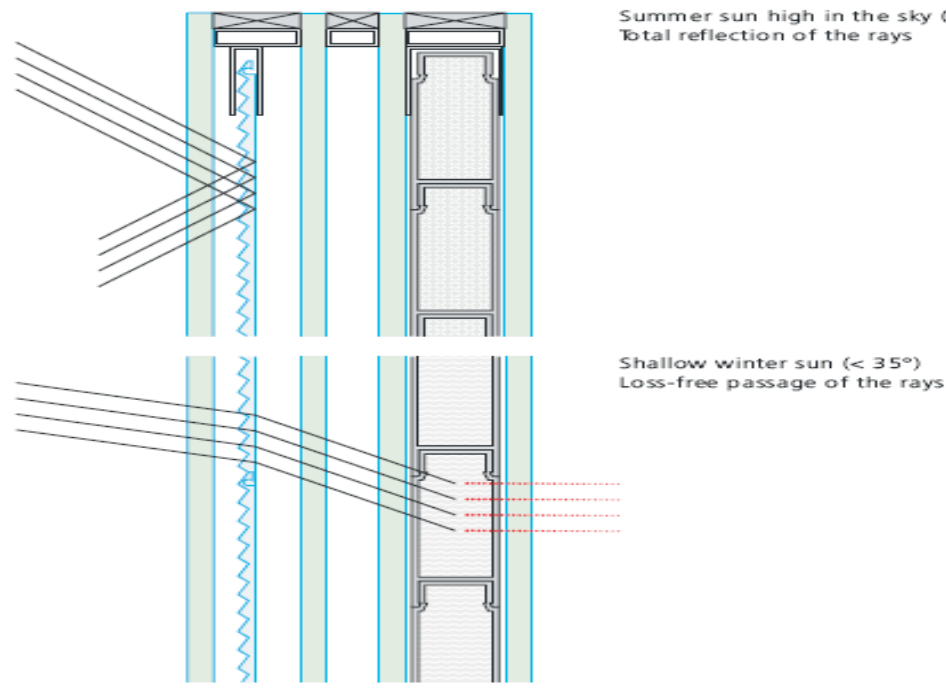

Figure I.5 - Glass X detail (Peyerbeer, 2005) 
Clima 26 by Maxit is a trowel-on internal plaster finish in a gypsum base for wall finishing with added thermal insulation (Schmidt, 2009).

Plus CelBloc, produced by $\mathrm{H}+\mathrm{H}$ Celon combines the insulation properties of aerated concrete with the heat capacity of Micronal $\circledast$ PCM to create a building block with superior thermal performance (BASF, 2008).

Illkatherm system, developed with Ilkazell combines SmartBoard $\AA$, capillary tube mats and rigid PUR foam to create ceiling panels that can be linked to an existing cooling water circuit via a 'plug and play' process (BASF, 2008).

DuPont launched its answer to the issue of installing PCMs in buildings in December 2006. Energain $\AA$, is a paraffin based PCM held in a polymer matrix between two layers of aluminium. Although launched in 2006, the earliest referenced installation is in 2008, at the Hammond High School in Norfolk where $600 \mathrm{~m}^{2}$ of Energain was installed into the ceilings of classrooms as an alternative to concrete soffits. This meant the proposed precast concrete roof became a lightweight timber construction. Also in 2008, at Nouveau bâtiment HQE Voirie of Grand Lyon in Venissieux, Energain was installed behind wall linings and in the ceiling plenum. Both applications are described by DuPont as "successful" and "preliminary results are in line with the expectations of thermal comfort and energy savings" (Du Pont, 2010). However, no detailed information is available about what was measured or how much energy was saved.

Also in 2006 Knauf launched SmartBoard $® 囚$ which has been installed in a number of realised buildings in Germany. These include the 3 Liter-Haus in Ludwigshafen, Büroneubau der Badenova in Offenburg, DSC der LUWOGE/Fortisnova, Ludwigshafen, Hotel und Bürokomplex in Berlin, Gotzkowskistraße, Haus der Gegenwart in München, Hölderlin Gymnasium in Lauffen am Neckar, and the Sonnenschiff Passivhaus Bürokomplex in Freiburg (BASF, 2004). These installations appear to see the use of PCMs as a component in a larger design goal of reducing energy use to near zero. Rather than seeing use of PCMs as a simple exchange of the old wallboard for the new product, the PCMs are used in conjunction with a number of other energy saving innovations. These buildings also seem to be 'show' or expo type buildings, and as such are like marketing tools built by the manufacturers in conjunction with government initiatives. Table 2 - PCMs in realised projects below describes some of these projects. 


\begin{tabular}{|c|c|c|c|c|c|c|c|c|c|}
\hline Project Name & $\begin{array}{l}\text { Project type } \\
\text { (Commercial } \\
\text { / Residential) }\end{array}$ & PCM Type & $\begin{array}{l}\text { System } \\
\text { Type } \\
\text { (Passivel } \\
\text { Active) }\end{array}$ & $\begin{array}{l}\text { Project } \\
\text { Size } \\
(\mathrm{m} 2)\end{array}$ & $\begin{array}{l}\text { PCM } \\
\text { Amount }\end{array}$ & $\begin{array}{l}\text { Phase } \\
\text { change } \\
\text { temp. } \\
\left({ }^{\circ} \mathrm{C}\right)\end{array}$ & $\begin{array}{l}\text { Energy } \\
\text { Saving } \\
(\mathrm{kWh} / \mathrm{m} 2 \mathrm{a})\end{array}$ & $\begin{array}{l}\text { Heating } \\
\text { or } \\
\text { Cooling? }\end{array}$ & $\begin{array}{l}\text { Reason for } \\
\text { innovation }\end{array}$ \\
\hline 3 Litre House & Residential & $\begin{array}{l}\text { Smartboard } \\
\text { Maxit Clima }\end{array}$ & Active & 900 & Not Found & 23 & $\begin{array}{l}\text { Inconclusive } \\
\text { due to } \\
\text { multiple } \\
\text { innovations }\end{array}$ & Cooling & $\begin{array}{l}\text { Lower energy } \\
\text { use }\end{array}$ \\
\hline Sonnenschiff & $\begin{array}{l}\text { Combined } \\
\text { Retail/Office/ } \\
\text { Residential }\end{array}$ & $\begin{array}{l}\text { All stated as } \\
\text { Micronal. I.e. } \\
\text { Smartboard } \\
\text { and/or } \\
\text { Clima }\end{array}$ & Passive & 6,500 & Not Found & 23 & $\begin{array}{l}1,000,000 \text { but } \\
\text { largely due to } \\
\text { PV }\end{array}$ & Cooling & $\begin{array}{l}\text { Comfort and } \\
\text { optimised } \\
\text { energy }\end{array}$ \\
\hline Badenova & Commercial & Maxit Clima & Passive & 5000 & Not Found & 23 & $40^{*}$ & $\begin{array}{l}\text { Heating \& } \\
\text { Cooling }\end{array}$ & $\begin{array}{l}\text { Low tech, } \\
\text { low energy }\end{array}$ \\
\hline Gotzkowskistraße & Commercial & Maxit Clima & Active & & $\begin{array}{l}1100 \mathrm{~m} 2 \\
(7 \text { metric } \\
\text { tonnes) }\end{array}$ & 23 & Not Found & Cooling & Comfort \\
\hline Engelhart \& Bauer & Commercial & $\begin{array}{l}\text { llkazell } \\
\text { chilled } \\
\text { ceiling }\end{array}$ & Active & 900 & Not Found & 23 & 144 (90\%) & Cooling & $\begin{array}{l}\text { Comfort and } \\
\text { optimised } \\
\text { energy }\end{array}$ \\
\hline $\begin{array}{l}\text { Solar Decathlon } \\
\text { House }\end{array}$ & Residential & $\begin{array}{l}\text { PlusICE EI5 } \\
\text { Macro } \\
\text { encapsulated }\end{array}$ & Active & $\begin{array}{l}\text { Not } \\
\text { Found }\end{array}$ & Not Found & 15 & Not Found & Cooling & $\begin{array}{l}\text { Comfort and } \\
\text { optimised } \\
\text { energy }\end{array}$ \\
\hline $\begin{array}{l}\text { School Building } \\
\text { Diekirch }\end{array}$ & Educational & Smartboard & Passive & $\begin{array}{l}\text { Not } \\
\text { Found }\end{array}$ & Not Found & $\begin{array}{l}\text { Not } \\
\text { Found }\end{array}$ & Not Found & Cooling & $\begin{array}{l}\text { Comfort and } \\
\text { optimised } \\
\text { energy }\end{array}$ \\
\hline
\end{tabular}

* This is a reverse calculation from a table produced in German, but the data is somewhat contradictory and confusing

Table 2 - PCMs in realised projects

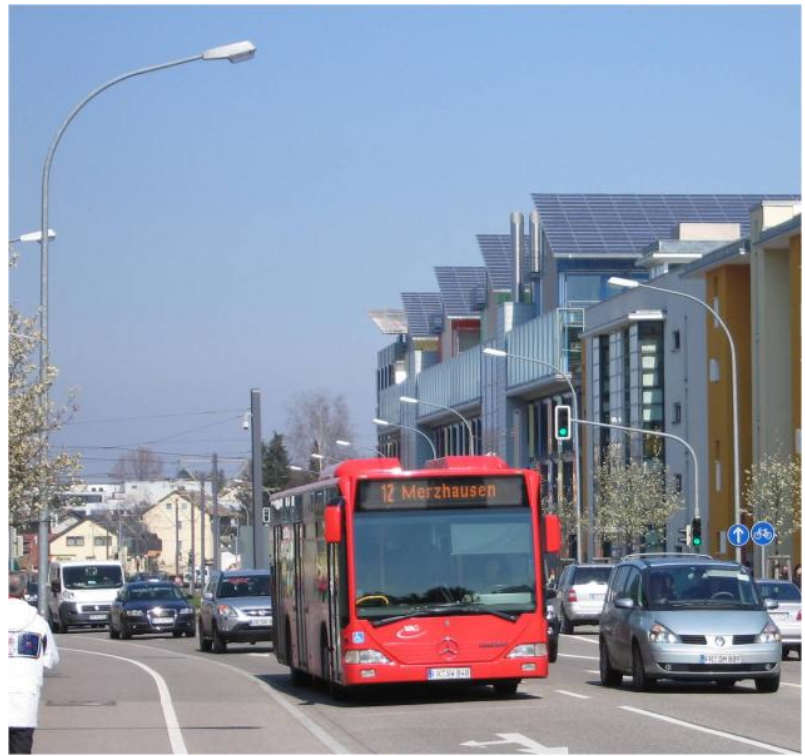

Figure I.6 - Sonnenschiff positive energy commercial building with visible PV roofs, and unseen

PCMs (Vale, 2007) 
The 3-Liter-house in The Brunck Quarter, Ludwigshafen, Germany was a 2001 modernisation of a 195 I apartment building historically consuming 25 litres of heating oil per square metre per year. The conversion was undertaken by Luwoge, the housing subsidiary of BASF. The goal was to lower the oil consumption to 7 litres, although the expectations were exceeded and a dramatic drop to 3 litres was achieved. The achievement was due to a seven innovations; new $20 \mathrm{~mm}$ Neopore insulation foam was installed over the exterior walls and in the roof, passive solar heating from new large new glazed areas, triple glazing, active building ventilation with $85 \%$ heat recovery, efficient heat and electricity generation from the installation of a new miniature power plant in the cellar, and PCM trowel-on plaster to interior wall surfaces, together with a 3 year scientific assessment and commissioning period. In addition to this the tenants selected for the building are BASF employees and are trained in how to use the innovations to maximum effect (Greifenhagen, 2004). Due to the complex design nature of the various innovations, while the overall result is undeniably positive the portion of the success attributable to the PCM is not able to be individually assessed. This, as suggested above, is a problem for designers who want to convince clients to use PCM products.

\section{THE 3-LITER-HOUSE -}

An innovation in the modernization of old properties
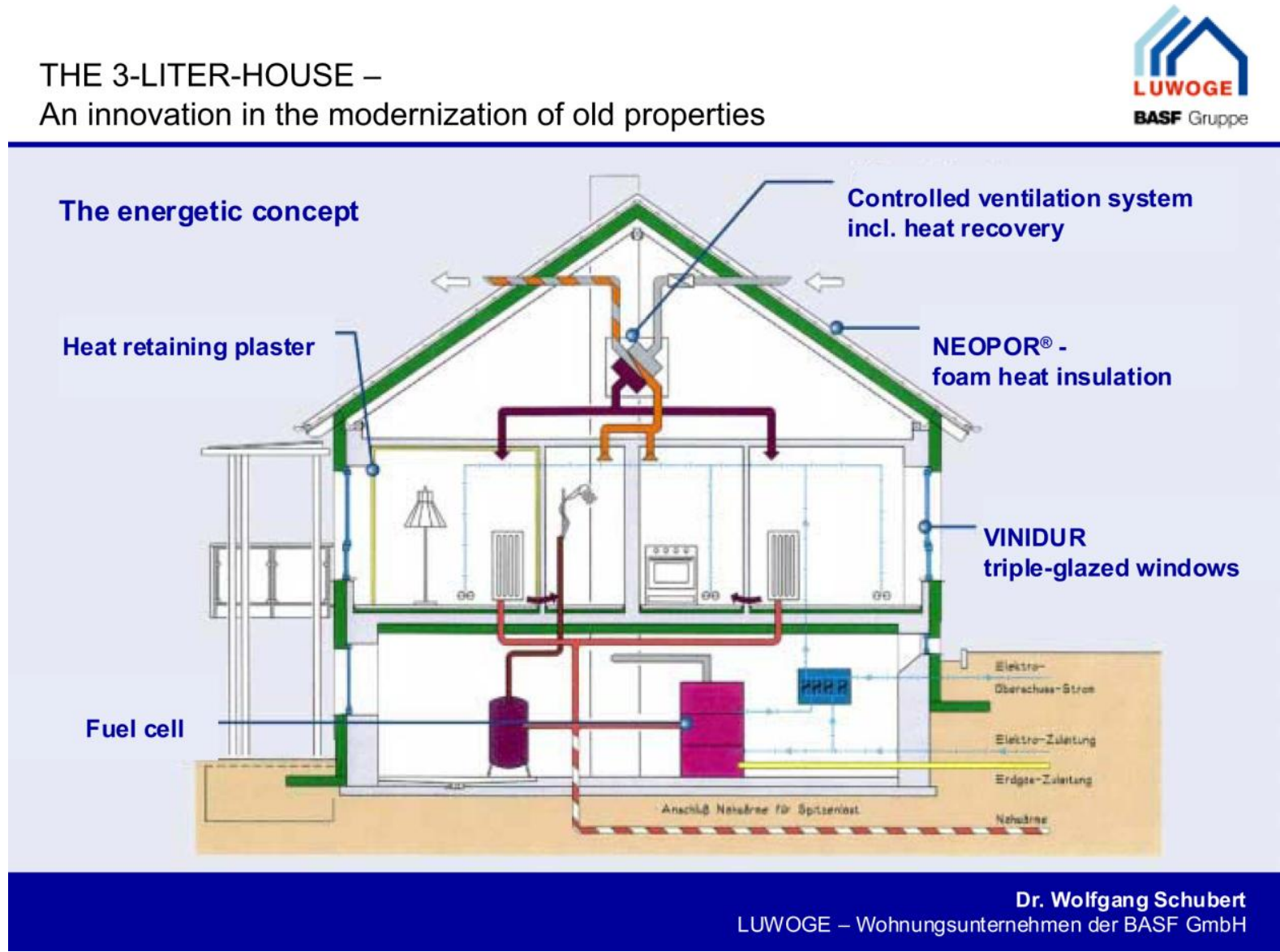

Figure 1.7 - The 3-Litre House detail (Schubert, N.d) 


\section{I.4.I Economics of PCMs}

Peippo estimated in 1991 that the economic payback time for his proposed PCM impregnated wall board was ten to twenty years depending on the location, based on a simulated 6-15\% energy reduction when modelled for buildings in Helsinki and Madison respectively and due to the low (US\$I5 per GJ) cost of conventional heating energy in the regions modelled at that time. The national average electricity cost in New Zealand in 1991 was approximately US\$13.76 (NZ\$23.33) per GJ, compared with approximately US\$27.42 (NZ\$47.45) per GJ in 2009 (Ministry of Economic Development, 2008). With the rising energy costs of recent years it could be anticipated that the payback time would be reduced. However, Peippo's research was based on the immersion bath technique for impregnating the board (Peippo, Kauranen, \& Lund, 1991 a, p. 264) which has since been shown to fail due to evaporation (Farid, 2009) and the microencapsulated PCM wall board, which does not evaporate, is more expensive to manufacture. Peippo approximated the cost of industrial grade fatty acid suitable for his immersion technique to be US\$1.5/kg in 1991, and the current cost of paraffin PCM as used in currently marketed products (see above) is approximately US\$8/kg (NZ\$10.70), and for a microencapsulated product US\$32/kg (NZ\$43.70). Estimated costs for supply of SmartBoard $\AA$ in New Zealand via Knauf in Germany (Bauer, 2009) indicate it to be about ten times the cost of regular gypsum board at approximately $\$ 10.40$ (see chapter 3.2 ). Fixed costs of other PCM building products are difficult to establish, especially in New Zealand, as there is not yet an established supply chain. The current cost of fatty acid based PCMs are slightly harder to estimate, as one of the key issues is to create a PCM from a renewable energy source, such as the sources that are being used for biofuels. Although deemed 'renewable' many crops used for biofuels, such as soybean oil, yellow grease, palm oil and sugarcane are competitive food stocks, the use of which can have far reaching opportunity costs, limiting supplies available for other use. Current research suggests that microalgae based biodiesel is the only renewable biofuel with the potential to completely replace petroleum based fuels without affecting food supplies or any other crop products (Chisti, 2008), however, these algae producing facilities will still occupy land resources so there could still be competition with using the land for food. Another important issue is that comparing fuel production costs by weight or volume is not entirely accurate as the energy content varies, generally reducing in non-petroleum based sources (Chisti, 2008).

When considering the possible cost of producing a fatty acid based PCM it is necessary to look at the cost of biofuels but it is important to factor in the cost of converting the fuel into the PCM. To make this comparison it is necessary to look back at a PCM product for which the production cost is known, that of paraffin. One 42 U.S. gallon barrel of crude oil weighs $138.8 \mathrm{~kg}$ and currently costs approximately US\$100 (BP, 2010), making $\$ 2.38$ per gallon or 72 cents per $\mathrm{kg}$. The cost of the refined paraffin PCM, as above, is approximately US $\$ 8$ per kilo, therefore disregarding any possible 
subsidisation of the end product by saleable by-products, it could assumed there would be a conservative factor of a 10 fold cost increase from the fuel to the PCM.

The costs of production of the fuel only are listed below.

\begin{tabular}{|c|c|c|c|}
\hline \multirow[b]{2}{*}{ Costs and Subsidies } & \multicolumn{3}{|c|}{ Fiscal Year } \\
\hline & 2004 & 2005 & 2006 \\
\hline Variable Cost & 2.55 & 2.54 & 2.49 \\
\hline CCC Base Production Payment & -0.43 & -0.22 & 0 \\
\hline $\begin{array}{l}\text { Variable Cost of Base Production } \\
\text { Net }\end{array}$ & 2.12 & 2.32 & 2.49 \\
\hline Variable Cost & 2.55 & 2.54 & 2.49 \\
\hline $\begin{array}{l}\text { CCC Additional Production } \\
\text { Payment }\end{array}$ & -1.45 & -1.46 & -1.47 \\
\hline $\begin{array}{l}\text { Variable Cost of Additional } \\
\text { Production, Net }\end{array}$ & 1.10 & 1.08 & 1.12 \\
\hline
\end{tabular}

Table I.3 - Soybean oil biodiesel production costs and subsidies, 2004-2006 (2002 Dollars per Gallon) (Radich, 2004) 


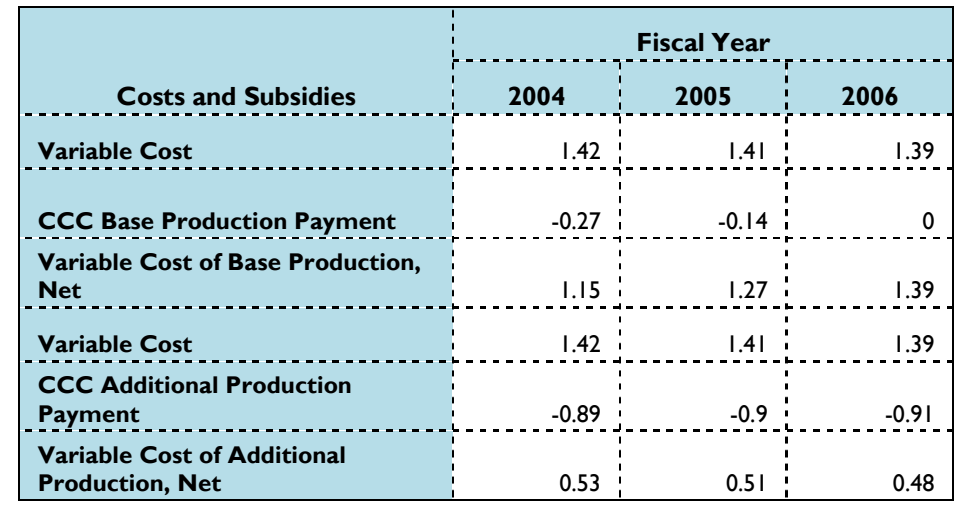

Table I.4 - Yellow grease biodiesel production costs and subsidies, 2004-2006 (2002 Dollars per Gallon) (Radich, 2004)

\begin{tabular}{|c|c|c|c|}
\hline Marketing Year & $\begin{array}{c}\text { Soybean } \\
\text { Oil }\end{array}$ & $\begin{array}{l}\text { Yellow } \\
\text { Grease }\end{array}$ & Petroleum \\
\hline $2004 / 05$ & 2.54 & 1.41 & 0.67 \\
\hline $2005 / 06$ & 2.49 & 1.39 & 0.78 \\
\hline $2006 / 07$ & 2.47 & 1.38 & 0.77 \\
\hline $2007 / 08$ & 2.44 & 1.37 & 0.78 \\
\hline $2008 / 09$ & 2.52 & 1.4 & 0.78 \\
\hline $2009 / 10$ & 2.57 & 1.42 & 0.75 \\
\hline $2010 / 11$ & 2.67 & 1.47 & 0.76 \\
\hline $2011 / 12$ & 2.73 & 1.51 & 0.76 \\
\hline $2012 / 13$ & 2.8 & 1.55 & 0.75 \\
\hline
\end{tabular}

Table I.5 - Projected production costs for diesel fuel by feedstock, 2004-20||3 (2002 Dollars per Gallon) (Radich, 2004)

By comparison the current estimated cost of producing algal biofuel with the equivalent energy content of petroleum is approximately US $\$ 3000$ per ton or US $\$ 880$ per barrel (Chisti, 2007, p. 30I). This works out at US $\$ 21$ per gallon or nearly 10 times bio-fuel from soya bean oil and nearly 20 times the cost of that from yellow grease. Given it was suggested above there would be an additional 10 fold increase in cost in going from fuel to PCM, replacing petroleum based PCMs with natural products is going to increase costs unless these products are truly waste, such as tallow (Bhatti, Hanif, Qasim, \& Ata-ur-Rehman, 2008). This again suggests that the advantages of using the product, because of its cost, must be made explicit to designers.

An example where this could have happened but has not is the 3-Liter-house. For this conversion the annual saving in heating cost for each of the 9 flats is 880 euros per year, a reduction from 1000 euros to 120 euros. The total costs of the refurbishment of the block of 9 flats was 1.5 million euros, with 400,000 euros being attributed to the "Energetic Modernisation" and 400,000 euros being subsidised and carried by the partners. The 400,000 for "Energetic Modernisation" alone 
equates to a 50 year financial payback based on heating cost savings. Again, the payback for the PCMs alone is impossible to discover from the data available.

\subsubsection{Availability of PCMs}

Whilst the products referenced in chapter 1.4 above are theoretically available on the market the reality is access to the materials is very limited. Any projects found that incorporate the various PCM materials are pilot projects that have been conducted in conjunction with the various developing companies. As a consequence, access to any data or performance studies is limited to advertising materials and press releases, any supply change for the released products has not been found. In New Zealand, the local branch Sto (a German plaster cladding products company) had been considering the possibility of introducing SmartBoard $\AA$ in 2009 but in 2010 were told that the product had been removed from the market for redevelopment with no specific information given. Maxit who had claim to Clima 26, the trowel on product, underwent a company restructure/merger with Weber group and any previously available information disappeared. The only contact found to make any comment on the developing products or availability thereof was Peter Schossig of Fraunhoffer, the parent research and development company responsible for SmartBoard $\circledast$ and clima 26. When asked, he sent a summary of the draft information in this chapter stating it was accurate to the best of his knowledge and he was not aware of any further products in development. In New Zealand for the only known built project incorporating pcm building products, NZi3, the systems engineer sourced SmartBoard $@$ direct from the manufacturer BASF in Germany as no supply chain in New Zealand was available.

\section{I.5 University of Auckland}

The University of Auckland Department of Chemical and Materials Engineering have been working with PCMs for more than 25 years (The University of Auckland, 2010). In 2002 funding was obtained for further research entitled 'New Materials for Phase-Change Thermal storage' of which this current project is a part.

The University of Auckland have extensive facilities for testing PCM materials both in the Research Centre for Surface and Materials Science (RCSMS) laboratory within the Engineering School and at the test facilities at the Tamaki campus. Staff and postgraduate students are working on the development of suitable phase change materials, including those based on fatty acids to give a cheaper product, and their encapsulation, and studying the effect of using these PCM materials in a built environment, mostly through simulation. They are also looking at the development of PCMs for refrigeration, glass houses, laptop pads and lithium batteries, and are working on PCM composites 
with graphite to improve conductivity. The focus of this part of the research is the use of PCMs in buildings.

\section{I.6 Commercial and Residential Buildings}

Home heating accounts for $35 \%$ of the average domestic power bill, or $4.3 \%$ of national energy consumption in New Zealand. Office heating/cooling is approximately $40 \%$ of commercial energy use, making a further $3.8 \%$ of national energy consumption in New Zealand (Mithraratne, Vale, \& Vale, 2007, p. 49) (Cosgrove, 2006). The reasons for wanting to reduce this usage are both financial and environmental. Financial reasons are clear, the less money spent as an individual or business on energy needs, the more money available for other things. Ecologically, awareness in the general population of the growing need to reduce human use of finite natural resources is increasing (DEFRA, 2008) (Research New Zealand, 2008). Further to this, comfort and health resulting from appropriate conditions in the interior environment are a factor. This year the government has recognised the poor conditions in New Zealand homes, and the effect these have on health, by initiating a home insulation subsidy scheme for private home owners (EECA, 2010). This scheme is to be funded via councils, banks and power companies. Home owners will be able to get a loan from the government for installation of ceiling and underfloor insulation in homes built before 2000, only two-thirds of which will have to be repaid. Providing warmer, more efficient homes in the future is no longer thought good for just the individual but has become essential for the nation.

PCMs in their current state of development, although much more expensive than available lightweight insulation materials (for example fibre glass batts), also have the potential to reduce the energy needed for space heating and cooling whilst improving the comfort of the space, in residential and commercial applications. This is because better use can be made of the "free" energy of the sun coming through windows. This will melt the waxes which then solidify once the temperature drops in the evening returning the heat to the space when it is most needed. In cooling situations, taking the energy out of the air from solar gain because it is absorbed by the PCMs reduces the cooling load. Current research indicates that the environmental conditions created, or enhanced, by PCM products are suitable for the commercial environment due to the usual occupation hours of commercial buildings (Du Pont, 2010). Basically, offices are occupied when the sun is likely to shine which generates a cooling load. Whilst historically, cellular office environments with solid walls on which to apply any of these wallboard products were common, the new office environment has many fewer walls (Duffy F. , 1997) because of the move to open planning and many of the walls that are installed are varieties of glazed partitioning, not suitable for the application of opaque wallboard (see chapter 3.I.I). In addition to the unavailability of wall surface it is also uncommon for office buildings in New Zealand to have gypsum board type ceilings as found in houses. This is because of 
the need for access into the ceiling plenum, and consequently office ceilings are commonly a suspended grid of fibrous tiles. Because PCMs are better suited to cooling than to heating (Du Pont, 20I0) due to the temperature shifts required for regeneration this would indicate that there are, perhaps, better opportunities for the development of PCMs into products that are more suitable for commercial application.

Although the merits of an open plan workspace have again recently been questioned (Oommen, Knowles, \& Zhao, 2008) the fact remains that due to work place economics, open planning means a saving of up to $20 \%$ in development costs (Oommen, Knowles, \& Zhao, 2008, p. 37), so it is unlikely such a configuration will soon be replaced by a cellular office arrangement. The advantages of the 'new' open-plan work environment are the increased spatial flexibility and the ability to choose a space fit for the current task. For many commercial businesses this means defining operating zones. These are normally allotted spaces in an open plan setting for the main tasks performed, while maintaining connection with co-workers and the workings of the office. There will also be quiet spaces for individuals performing temporary tasks requiring concentration, and meeting rooms for group discussions where they will not disturb co-workers. Break-out spaces for informal gatherings are also popular. In reality, many offices at the lower end of the cost spectrum do not provide these additional spaces and staff members have little more than a desk in an open room and access to a tea station. These environments offer the least opportunity for sheet type PCM installation. This raises the question of whether there is a better PCM based product than wallboard (or trowel on PCM plaster) for office interior applications.

\section{I.7 Alternative Uses}

PCMs in a more basic state are used as a coolant in liquid (water) based cooling systems. Contained PCM modules are immersed in a reservoir in the cooling system loop where they absorb the heat from the system during the day and hold it until the temperatures cool below the PCM melting point at night when they release the energy (heat) back into the system ready to start the cycle again when temperatures rise (Advanced Environmental Concepts Pty Ltd, 2008).

In the Melbourne City Council building (often referred to as Council House 2 or $\mathrm{CH} 2$ ) a combination radiant cooling system is used to achieve a $20 \%$ reduction in cooling demand (Fortmeyer, 2009). Exposed high mass concrete ceilings operating on a sophisticated night purge system are combined with chilled ceiling panels. These are supplied by large tanks at basement level each containing nearly 10,000 stainless steel balls filled with a salt suspension PCM of freezing point 10 degrees Celsius. These systems with the aid of shower towers to cool the ground level, aid in maintaining the building's temperature at $21^{\circ} \mathrm{C}-23^{\circ} \mathrm{C}$ (Melbourne City Council, 2008). 
Other documented instances of inclusion of PCMs in cooling systems include the following.

Nottingham Passive Cooling - Passive ceiling heat pipes and PCM comfort cooling application at a research facility in Nottingham University in the UK.

EIDOS Heat Pump Application - Geothermal heat pump system complete with both hot and cold sides of the system having PCM based TES, where granular PCMs are absorbed into building materials, such as plasterboard or concrete to aid the balance between temperature extremes, applied to the heating and cooling system in an Italian Electronics factory.

Gosnel City - Large scale cool PCM storage as part of the chilled water circuit for a West Australian office complex.

Passive free cooling application for school environment - In the Sir John Thursby College Heat Pump System there is a water to water heat pump PCM energy storage application for both hot and cold sides of the circuits using FlatICE product in pressurised tanks. This school has been described as one of the lowest energy schools in the UK (Institution of Mechanical Engineers, 2010) but no performance data is yet available.

China Shipping FlatICE System - Office building using excess capacity of the chillers over-night providing a cool PCM storage TES for the passive chilled ceiling circuit for a UK office building application.

Burnley College - Large scale ground source heat pump PCM energy storage application for both hot and cold sides of the heat pump circuits using BallICE product.

Pendle Vale Heat Pump - Large scale ground source heat pump PCM energy storage application for both hot and cold sides of the circuits using FlatICE product in pressurised tanks.

Shuttleworth College Heat Pump - Large scale ground source heat pump PCM energy storage application for both hot and cold sides of the circuits using FlatICE product in atmospheric tanks.

(PCM Products Ltd, 2009)

Although these systems are of interest as part of a comprehensive low energy building system, this study is primarily concerned with PCMs that can be applied directly to the interior environment.

Other published researched uses of PCMs are briefly described below. 
SCATES (Solar Collector And Thermal Energy Storage) window system - The window frame itself contains PCMs housed in multiple layers. Though designed for light weight construction this use of PCMs requires a large depth of frame more suited to the types of construction typically found in the United Kingdom than that of New Zealand (Skates, 2006).

Fabric coatings/ textiles, footwear, foams and bedding - Micro encapsulated PCMs are embedded in textiles and foams to enhance thermal comfort. None of these products appear to have made it to the market but the chemical producers market them as possibilities (Microtec laboritories, 2010).

Refrigeration - PCMs can be used in refrigeration to protect against power outages or when constant connection to a power source is not possible, for example in shipping.

Thermal protection of electronic devices - Electronic components product a lot of heat, and as the power of computer devices increases so too does the need to develop more efficient ways of moving the heat away from the components. Using a slurry of microencapsulated PCMs in a loop system (similar to a micro scale building cooling system) is an effective way to do this and due to the relatively tiny amount of PCM material used this is a financially viable option. This is an application currently being investigated by the University of Auckland (see above).

However, commercialisation of the above products seems unlikely at present.

This review of PCM use in buildings and of other products has revealed a lack of clear information about how the product contributes to the overall energy performance of the building or system within a building. As stated above this is vital for architects and interior designers who need to tell clients at least the estimated savings that will accrue from spending money on energy saving products. Where these estimated savings can be backed up with information from monitored buildings the argument for the use of PCMs could be made more convincing. 


\section{Background}

“...one reason we're in so much trouble is that our modern culture is paradoxically behind the times, still assessing the world the way it did in the nineteenth or even eighteenth centuries; as a place of inexhaustible resources, where man is at the pinnacle of creation, separate from and more important than anything around him.” (Suzuki \& Dressel, 2004, p. 6)

\section{I Energy Efficiency, Peak Oil and Solar Gain}

Energy efficiency is using less energy to provide the same level of energy service. For example, insulating a home allows a building to use less heating and cooling energy to achieve and maintain a comfortable temperature (Herring \& Roy, 2007, p. 195). At a time when sources of fossil fuels are being depleted (see below), efficient use of such fuels becomes increasingly important.

"Efficient energy use is achieved primarily by means of a more efficient technology or process rather than by changes in individual behaviour" (Diesendorf, 2007). But, as discussed in chapter 2.2, energy efficiency must be used with enough knowledge, and incentive to temper the scale of the rebound effect.

"The term Peak Oil refers to the maximum rate of the production of oil in any area under consideration, recognising that it is a finite natural resource, subject to depletion." Colin Campbell' (ASPO International).

Globally, Peak oil is the point in time when the maximum rate of global petroleum extraction is reached, the point at which the supply of crude from oil fields around the world top out, after which depletion occurs. It is argued whether this point has already been reached, or how soon it is to be reached, but regardless the world demand for oil is still increasing, on average $1.76 \%$ per year from 1994-2006, putting ever more pressure on the finite stocks of a natural resource. Regardless of the scale of optimism, without reduction of the worldwide thirst for oil, in the end "you're talking about a few years one way or another," according to Alfred Cavallo, an energy consultant in Princeton, New Jersey (Appenzeller, 2004)

The world's biggest consumer of oil, the United States, taxes gasoline at a very low rate 2 . One gallon ${ }^{3}$ of gasoline can be cheaper than a bottle of water "making it too cheap for most people to bother conserving" (Appenzeller, 2004). While continuing to use approximately $25 \%$ of the world oil (BP, 2008, p. II) supply annually, regardless of worldwide peak oil, the US reached its peak production in

\footnotetext{
' ASPO founder and Honorary Chairman

${ }^{2}$ Average 43 cents a gallon, instead of dollars, as in Europe and Japan (Appenzeller, 2004).

3.79 Litres
} 
1970 (ASPO, 2002, p. 6) and is now consuming the lion's share of global production. While New Zealand's oil consumption per capita is much lower than that of the US, approximately $65 \%$ of the latter (BP, 2008), as a non-producing nation, the national consumption in excess of production per capita is almost equivalent.

While transport accounts for approximately $60 \%$ of all oil consumed globally (Heinberg, N.d.) , many forms of heating, the synthetic fabrics in clothing and furnishings, and the chemicals and plastics in many products and components of the building industry also started out as oil. In the face of a rapidly reducing resource alternative fuel material feed stock sources must be found sooner or later. "People should be doing something now to reduce oil dependence and not waiting for Mother Nature to slap them in the face....There are many things you can do to ease the transition," says Cavallo, "And you can have a very nice life on a sustainable system. Of course, not everyone is going to be driving SUVs." (Appenzeller, 2004).

In addition to the inevitable exhaustion of 'reasonably' obtainable crude oil, the process of extracting the oil has costs and risks beyond direct economics. The Deepwater Horizon oil spill in the Gulf of Mexico in April 2010 has provoked public outrage at BP. While it is considered the world's worst accidental oil spill in history, and undoubtedly has caused extensive damage to marine and wildlife impacting on fishing and tourism industries, it is by no means the first, nor has it cost the most lives. So while a catastrophe, a spill of this scale could hardly be considered unforeseen, yet the risk has been silently accepted through the expectation of having cheap and readily available oil. While in this instance BP, as the oil profiteer, are being labelled the villains it must be accepted that this is a crime of supply and demand, and as consumers of petroleum, and petroleum based products most of the global population has to take some responsibility. It should also be acknowledge that that rate of oil spillage into the Gulf of Mexico was $0.3 \%$ of total daily US oil consumption (Vale R., 2010). So whilst gallons of oil floating on the ocean and covering wildlife is an emotive image, it is ordinary usage that is the problem and alternative energy sources must be found and refined to reduce the demand for oil and the risks taken to extract that oil.

One sustainable source of energy is the sun and the sun has been used as a source of energy in buildings for centuries. Solar heat gain is the amount of heat produced, as an increase in temperature, in a building or space by solar radiation that is transmitted and flows inward, through windows or walls. The amount of solar gain increases with the strength of the sun, and with the ability of any intervening material to transmit the radiation. Passive solar building design aims to maximise solar gain within the building in the winter, to reduce or eliminate the need for auxiliary heating, and to control it in summer to reduce or eliminate the need for auxiliary cooling. Thermal mass is used to even out the fluctuations during a day, and between days or even seasons in some 
extreme cases, such as in the unheated (apart from the sun and incidental gains) thermally massive houses at Hockerton in the UK (see Figure 2.I). The composition and coating of the building's glazing systems can be designed to optimise the solar gain, as can its size, position and shading.

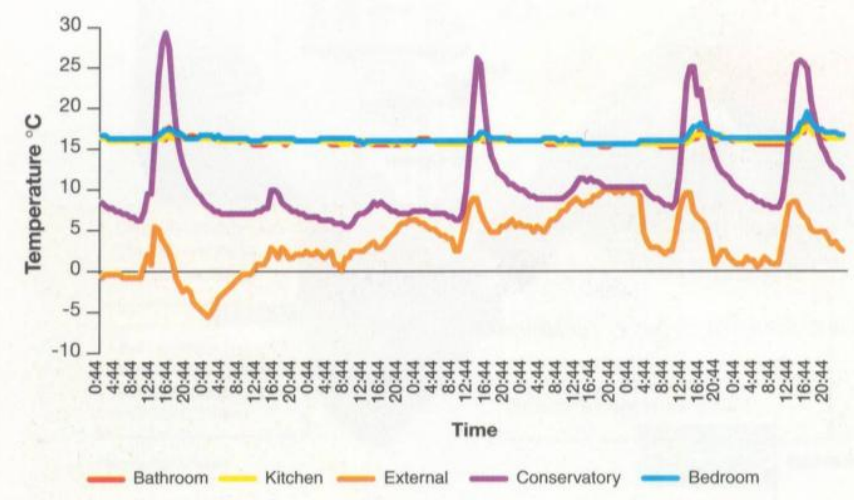

Figure 2.I - Effect of insulated mass on Hockerton Houses during a cold week (Energy Saving Trust, 2003)

\subsection{Sustainable Development, Sustainability and Sustainable Design}

Sustainable development "meets the needs of the present without compromising the ability of future generations to meet their own needs", a description coined by the Brundtland Commission in 1987 (World Commission on Environment, 1987, p. A/42/427). The term "sustainability" was used early as the 1970s to describe an economy "in equilibrium with basic ecological support systems." (Stivers, 1976). Sustainable development can be conceptually broken into three fields, these being environmental sustainability, economic sustainability and sociopolitical sustainability.

The concept of sustainable development recognises that in order to achieve environmental sustainability, economic and sociopolitical needs must also be met. In order for society to maintain commitment to environmental goals the solutions must be economically viable. However appealing the spiritual notions of saving the earth, it must be recognised that the role of industry and economics in driving the movement forward is imperative to enable people to have an environmental choice, as a collapsed economy and poverty drives people to survive by necessity, however un-environmental the attainment of those necessities may be.

Sustainable design is the practice of designing physical objects, the built environment, and services to comply with the principles of sustainable development. "Sustainable Design is a design philosophy that seeks to maximize the quality of the built environment, while minimizing or eliminating negative impact to the natural environment" (McLennan, 2004, p. 4). 


\subsection{Slow uptake of Sustainable Design}

"Sustainable development maintains an anthropocentric view and favours incremental change that does not challenge any existing entrenched powers or privileges, institutional reforms and technological advance. Sustainability, by contrast, promotes a biocentric view that places the human presence within a larger natural context, and focuses on constraints and fundamental value and behavioural change” (Cole, 2005, p. 2).

The New Zealand building act 2004 compelled that "buildings are designed, constructed and able to be used in ways that promote sustainable development" yet this is yet to be enforced by the New Zealand Building Code (Isaacs, 2010, p. 4). However, without a framework for enforcing change simply trying to persuade people to change their behaviour maybe not worth the effort.

"Try changing the position of the waste bin in your kitchen. Better still, get someone else to change it for you. And then count how many days it is before you stop going to the wrong place to deposit your waste." This describes a simple experiment suggested by Tim Jackson (Jackson, 2005, p. 3) to reveal the difficulties in changing people's behaviour.

From obesity to drink-driving to sustainable development policy, there are many societal issues facing the world today, motivating the need to identify the roots of human behaviour and develop strategies for behavioural change, convincing people to behave in more socially and environmentally responsible ways (Jackson, 2005). Whilst the importance of reasons for the motivations behind behavioural change is debated (Crompton, 2008, p. 23) it is widely accepted, irrespective of the effects of their behaviours, that changes need to be made in the lives of ordinary people (DEFRA, 2008) (Research New Zealand, 2008).

"An accurate basic assumption might be that most people are essentially selfish, which is a natural human reaction and indeed a natural evolutionary process for any animal. Quality of life for oneself and one's dependants is always a key driving force for anyone. Any benefits from environmental behaviour, and there should be benefits from every environmental behaviour, must be tangible, immediate and specific to the person carrying out the behaviour. Benefits at the society level are unlikely to be a significant driver of change; benefits should be as localised as possible.” (Hounsham, 2006, p. 139)

The difficulty is in providing a direct incentive that emphasises the larger goal, increases awareness of individual action and reduces the effect of a particular behaviour on the environment. Without the awareness of, and consequent action toward, the environmental consequences of people's behaviour, the risk of a take-back or rebound effect can counteract environmentally beneficial initiatives. 
"To put it simply the rebound effect is the extent of the energy saving produced by an efficiency investment that is taken back by consumers in the form of higher consumption, either in the form of more hours of use or a higher quality of energy use.” (Herring \& Roy, 2007, p. 195)

For example, consumers motivated by cost to switch appliances to energy saving equivalents (i.e. changing a $75 \mathrm{~W}$ incandescent light bulb for an $18 \mathrm{~W}$ compact fluorescent) may then feel comfortable leaving the devices running for longer periods of time, resulting in higher energy consumption than with the original higher input appliance. This economic principle, first examined in 1865 by William Stanley Jevons, and referred to as the Jevons Paradox, proposes that as technology increases in efficiency, consumption will increase. While the Jevons Paradox has been used to argue that energy conservation is futile, others argue that the increase in consumption indicates an increase in the standard of living, and government policy could be used to tax fuel consumption and keep cost at the same level (Wackernagel \& Rees, 1997).

Research indicates that in order for environmental strategy and products to penetrate the market they must endeavour to engage people on two levels. The first is an appeal to immediate selfinterest, either through cost-savings or providing a point of difference that the consumer can be proud of. This latter approach recognises people will spend more money on fine furnishings or big screen televisions, for self gratification, either immediately or through the feelings of increased status that the product or initiative brings (Crompton, 2008). However, once the initial buy-in has been achieved the second goal must be that the product enhances the user's awareness of the environmental function.

"With public sentiment, nothing can fail; without it, nothing can succeed. Consequently, he who moulds public sentiment goes deeper than he who enacts statues or pronounces decisions." Abraham Lincoln, 16th president of the United States of America (Hounsham, 2006, p. 16).

\subsection{Change Aversion, Scepticism and Apathy}

"Every great movement must be experienced in three stages: ridicule, discussion, adoption." John Stuart Mill, 1806-I873 (McLennan, 2004, p. 4)

Though PCM products have been developed and there is great interest in their capabilities from a range of industries, their uptake has been very limited. Stalled uptake can usually be attributed to two issues, scepticism and cost (Máté, 2009). In this instance scepticism is probably not the issue as the principles of using modern PCMs are well founded and proven (Vavan Vuceljic, 2009) and reducing energy is a big current issue (UNFCCC, 2007) that has reached the general population. However, there is a resistance to using improved materials many times the cost of the original. Here 
lies the importance of design input. It is commonly acknowledged that designers (and their clients) will validate expense in achieving a point of difference, but they expect visual gratification, or 'added value', for the effort (Máté, 2009). The PCM products currently available have been 'designed' by teams of scientists, driven by the technical abilities of the materials, and often using them to better existing products - in effect hiding the innovation in something that has already been accepted by the construction industry. Hiding innovation may work when the cost is comparable or the increase in cost small, but for a product like PCM SmartBoard $\AA$, which sells for approximately ten times the normal price of Gib, people want to see what they are paying for. The visual characteristics of PCMs performing their melt cycle are very interesting and elegant and exposing them, for instance, would give the user an awareness of their function and of the environmental conditions that would not otherwise be easily perceptible. With the possible exception of Glass-X none of the current products exploit this opportunity.

Had a design team been consulted at the point of conception of radical new ideas for how a material, like PCMs, might be used, the development might have taken a very different course. Instead of leaving development to scientists, whose expertise is in the chemistry of materials not architecture, allowing designers to develop the innovation into a new and better, rather than existing product, might produce something more radical and hence acceptable despite the cost. The fact many open plan office interiors make use of glazed partitions, as mentioned above, would seem to offer an opportunity for a visual PCM installation where the change in the material status would become part of the office environment. This would also connect the users with what was happening in that environment giving them an awareness of why changes occur. When the sun comes out the PCMs would change state from solid to clear liquid, like ice melting, or when they solidify they become milky. Making this visible would have produced a product like no other on the market, yet one that would still make a contribution to energy savings. People would be prepared to pay more for an innovative product and may also vie to be the first to use it, as this can be used as part of a firm's marketing strategy.

Well designed 'green' products might be used to appeal to a consumer's sense of materialism, with any luck replacing wasteful, short life products that might otherwise be used to get the shopper's fix. Solitaire Townsend, the founder of FUTERRA, a communications consultancy which advises the UK government on its Climate Communications Strategy, is quoted as saying: "You can't stop people from wanting status symbols, but you can make them aspire to different ones." (Crompton, 2008, p. I5) and in a radio interview with the $\mathrm{BBC}$ Townsend further elaborates this notion. "If I change my light bulbs and I put cavity wall insulation on my home and I turn all my lights out when I go to bed and half fill my kettle, it's not something which my neighbours can see; whereas if I put a wind turbine on my house or a solar panel on my house or park a Toyota Prius outside my front door, it's a social proof action. Now that 
doesn't necessarily mean that you did it for climate change. One of my friends has got a solar panel on the north-facing roof of her house. When I pointed put to her that's not necessarily the best place in the UK to be generating energy, she pointed out to me that I wasn't understanding why she'd done it. The north facing part of her house is the part that faces the street." (Crompton, 2008, p. 15). While this illustration perhaps does not show the best possible outcome of integrating sustainable initiatives in people's lives, it does show that there is some wisdom in designing products that visually communicate their function. Even if a few people take these up, the ultimate effect can be much bigger within a relatively short time.

"By definition every new idea is entertained initially by only a few people, leaving the majority either indifferent or hostile. The other side of the coin is that once a majority embraces an idea, it becomes an unstoppable force.” Wendy Gordon, brand research specialist (Hounsham, 2006, p. 17).

\subsection{Mass in Buildings}

All heavy materials have the ability to absorb, store and release heat, a property referred to as thermal mass when part of a building design. As thermal mass will absorb heat when the surroundings are hotter than the mass and release heat when the surroundings cool to a lower temperature than the mass, it provides a barrier against temperature fluctuations evening out internal temperatures.

The concept of using thermal mass in buildings to capture the free energy from the sun is not a new one, as the use of passive solar design whether for heating or cooling has been used in many countries for centuries. This necessity for heating and cooling the interior of traditional architecture without using mechanical equipment, together with advanced solar design in terms of urban planning, were first recorded by the Greeks and Chinese (Butti \& Perlin, 1980, pp. 3-13).

As the Romans claimed domination over ancient Greece they also claimed the ideas and architectures of the cultures they conquered, including the use of effective solar orientation in conjunction with high mass building materials. Also credited with the discovery of glass, the Romans discovered that while glass on the south side of a building enhanced warmth in winter, glass on the west side promoted over heating in summer. They used these principles as part of the design of large buildings, such as public baths.

2500 years ago the Greek playwright Aeschylus wrote of how only primitives and barbarians lacked the knowledge of turning houses to face the winter sun (Butti \& Perlin, 1980, p. 13). Similarly, Socrates said "Now, supposing a house to have a southern aspect, sunshine during winter will steal under the veranda, but in summer, when the sun traverses a path right over our heads the roof will afford an 
agreeable shade, will it not" (Xenophon, approx 37। A.D.). In the first century B.C. the Roman Empire dominated an expanse far greater than Greece, and the Roman writer Vitruvius recognised that its architecture must be designed to the local environment "One type of house seems appropriate for Egypt, another for Spain... one still different for Rome....It is obvious the designs for homes ought to conform to the diversities of Climate.” (Butti \& Perlin, 1980, p. 15)

Other ancient cultures also developed advanced solar techniques. The Persians built sophisticated Badgir or 'Wind Catcher' cooling towers which used high mass materials and airflow to provide relief from the hot arid conditions of the Middle East (Bahadori, 1994). For centuries master builders in Yazd, Iran have understood the subtleties of comfort temperature and the slight differences in surfaces and air volumes and used this knowledge to make otherwise uncomfortable spaces comfortable. Yazd has average maximum summer temperatures of 39 degrees Celsius in July, however the use of passive cooling systems and the adaptability of inhabitants to modify their use of buildings to utilise the most comfortable space at different stages of the day, means it is possible for people to make satisfactory lives in such extreme conditions. The towers, which rise on average 3-5 metres above the roof parapet level (Roaf, 2009), usually have two or more shafts, commonly four, which allow air to move both up and down the tower simultaneously. Windward vents combined with the low pressure area at the base of the tower force air down into the tower and vents on the leeward side create negative pressure to draw air out of the tower. As the air passes through the basement level it cools, due to the lower basement temperatures alone, or in enhanced (wealthier) systems by the additional effects of a Qanat or manmade underground water channel. Cooled air is then circulated back through the living spaces before being drawn out of the wind tower, creating cooling air movement as well as lower temperatures. 


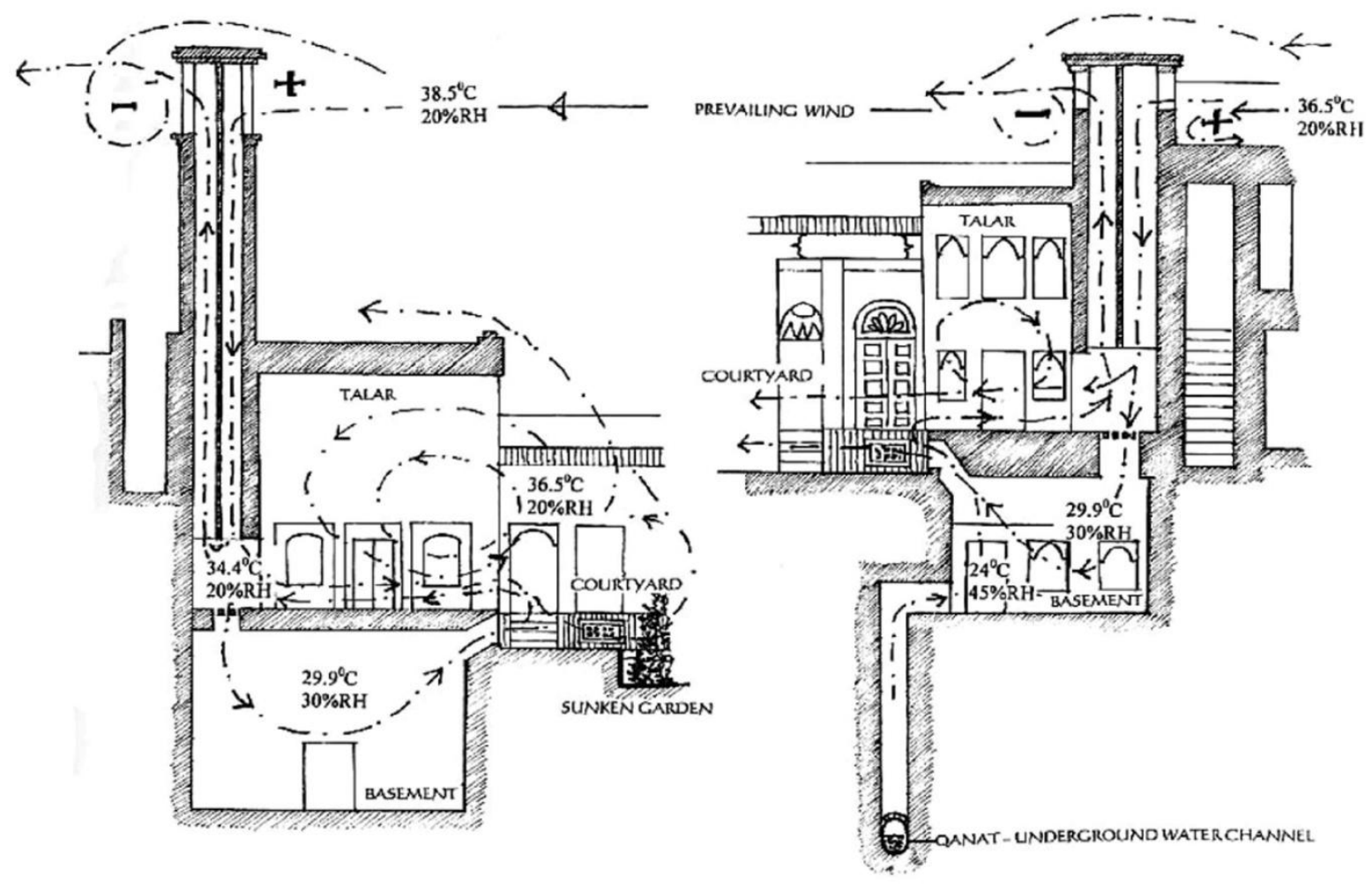

Figure 2.2 - Sections through two basements with Badgir, one linked to the Qanat introducing additional coolth (Roaf, 2009)

With the fall of the Roman Empire solar design was largely lost in Europe, and the revival of classical Greek and Roman Architecture during the Renaissance ironically failed to recognise the influence of solar design and consequently the wrong orientation of mansions created large, cold houses that needed to be artificially heated. While solar theory was lost and thousands of people died in the cold, insanitary, poorly planned slums of post industrialised Great Britain, good solar design and planning had continued in China unabated through the traditions of Feng Shui. These ensured that houses were clustered together and given the correct orientation to the sun but with rising land behind to protect the houses from the winter wind. Another advantageous Feng Shui principle was to have water in front the of village house cluster. This would have had the effect of reflecting low angle sunlight into the hoses, thus amplifying the solar gain in winter. 


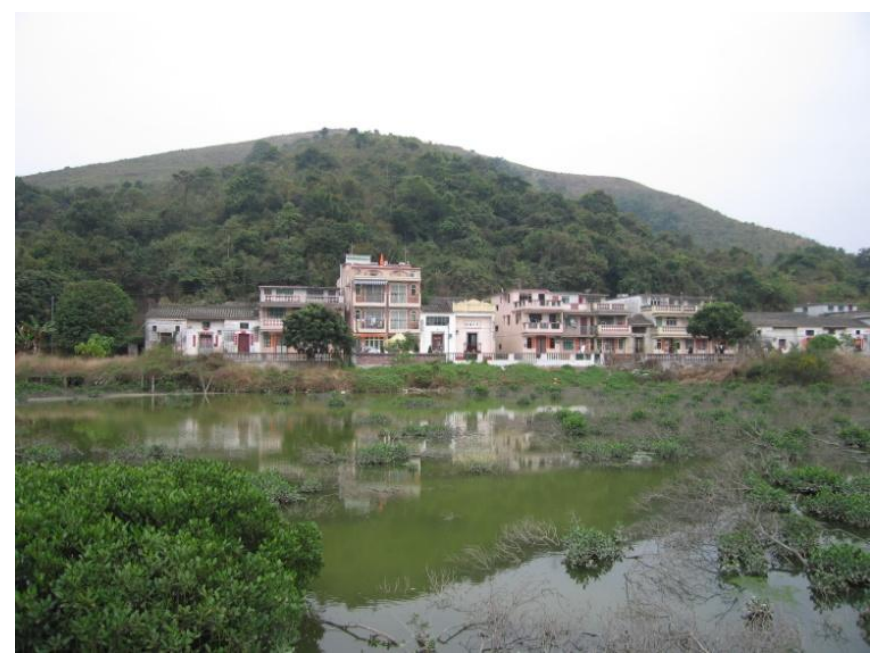

Figure 2.3 - Typical Chinese village built on Feng Shui principles (Vale, Personal Communication, 2010)

The revival of solar design began in Britain after Pasteur developed his germ theory and Sir Arthur Davies proved that ultraviolet light destroys bacteria. This suggested sunlight could prevent the spread of the epidemics that threatened entire cities and reformers demanded that something be done about the sunless, over-crowed slums. England's problems were repeated elsewhere throughout Europe and by the turn of the $20^{\text {th }}$ century many countries had legislated public health and town planning laws ensuring access for sunlight to all buildings (Unwin, 1909). While the main drive for this solar revival had been to use ultraviolet light to reduce disease, the side effect of solar gain in south facing houses in winter was a welcomed side effect.

Post World War I the economic reality for Germany was poor, as the victorious Allies were expropriating many national resources and large reparations were to be paid. This dim outlook and a drive for change led German development in many fields, including architecture. With saving fuel by enhanced use of the sun as a major goal, "sun orientation was considerably important because there is not much sunshine in Germany during winter, and, therefore, it was very much a concern to capture it" (Professor Emeritus of Urban Planning at Harvard, Wilhelm von Moltke) (Butti \& Perlin, 1980, p. 166). In the 100 years since, the Germans have made many of the more developed contributions to energy efficient design, including the use of mass and solar gain in buildings, and latterly the inclusion of phase change materials, see chapterl.4.

In America in the decades preceding and following the turn of the $20^{\text {th }}$ century solar water heating enjoyed a fashion and in the 1930s. Stimulated by developments in Europe, solar building design was considered 'pioneering' and continued with fluctuating interest (see chapter 1.3) until the oil crisis in 1973 when more significant interest was stimulated. 
Passive solar design relies on the ability to store the sun's energy. The way to do this without implementing technology to convert the energy to electricity is to store it in the form in which it arrives - heat. In order to store heat a material with high mass (or one that behaves as mass) is required. The materials that best perform this function are largely those that are little modified products of nature; water, rammed earth, mud, stone, concrete and clay bricks, with concrete being the most common is New Zealand buildings (Donn \& Thomas, 200I). While water is a very effective heat store it is largely impractical as part of building design. Mass materials have the double function of being both structural and heat absorbing whereas water can only do the latter and needs to be contained. Mass for passive heating is ideally located where it is exposed to direct sunlight (this may be through glass) but insulated from heat loss. For cooling, sun exposure should be limited and adequate ventilation to cool the mass must be provided.

"The effectiveness of thermal mass is influenced by the amount of insulation and glass, the site, and the climate in which the building is located. Because of these complex interactions it is not possible to generalise about how much mass to put into a house.... Thermal mass gains direct solar energy only when the sun shines. Once the room cools down, the heat flow reverses. This pattern means there is a concrete thickness beyond which there is generally no benefit in terms of solar energy storage." (Donn \& Thomas, 200I, p. 24).

Moreover, the mass has to be exposed to the space it needs to influence and cannot be covered by conventional internal finishes, like carpet. The limit of useful thickness for mass is also true of PCMs though, due to their conductivity, the thickness is much lower and more predictable.

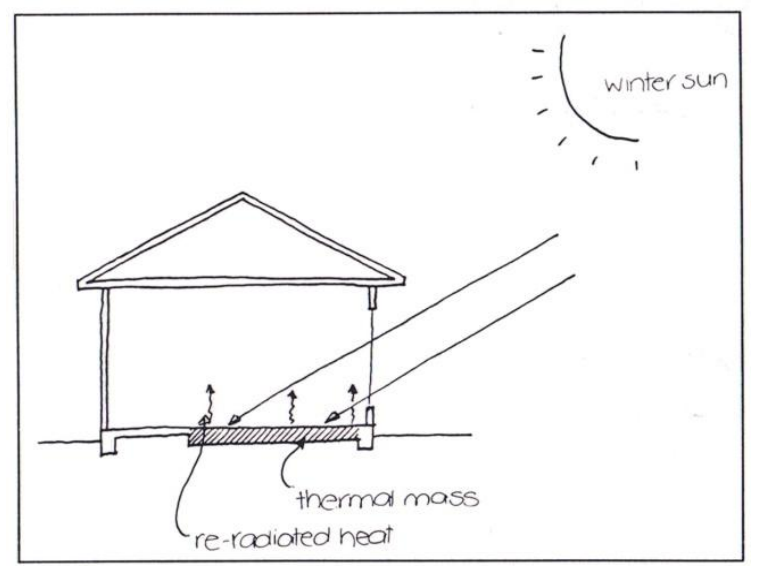

Figure 2.4 - Direct solar gain (Donn \& Thomas, 2001 ) 


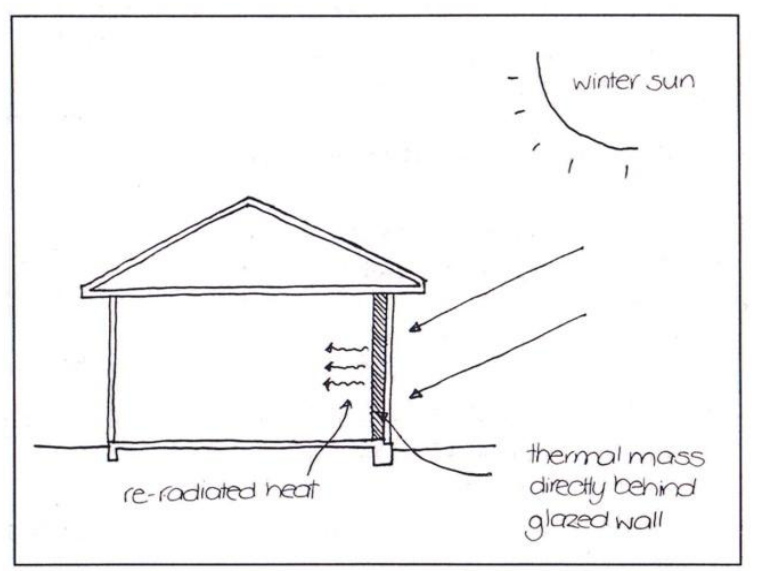

Figure 2.5 - Indirect solar gain (Donn \& Thomas, 200 I)

Other benefits of high mass building materials include reduced noise transmission, fire resistance and low maintenance, not all of which are applicable to PCM mass replacement materials.

\subsection{New Zealand Market Position}

In some ways, although New Zealand has a high level of home ownership, approximately $70 \%$ (Department of the Prime Minister and Cabinet, 2008), its residential buildings are not necessarily something of which the country can be proud. New Zealand homes are, on average $6^{\circ} \mathrm{C}$ below the minimum winter temperatures recommended by the OECD and World Health Organisation. In addition, $45 \%$ of homes show visible mould and the country has high Asthma and winter mortality rates (Allen and Clarke, 2007).

Householders are considered to be in fuel poverty if the cost of the energy requirements to provide a healthy indoor living environment exceeds $10 \%$ of their income, "the key idea here is that the fuel cost is attributed to what people would need to spend, not what they actually spend." Some 10-14\% of New Zealanders are estimated to be in fuel poverty (Lloyd, 2006). Research indicates that there is no direct link between income and indoor temperatures, as low temperatures prevail in New Zealand homes regardless of the level of income of the occupants (Callau \& Lloyd, 2010, p. 2). A study by Wellington School of Medicine at the University of Otago suggested "The efficiency of domestic energy is linked with health because money spent on energy cannot be spent on other necessities such as food." and that "Insulating existing houses led to a significantly warmer, drier indoor environment and resulted in improved self rated health, self reported wheezing, days off school and work, and visits to general practitioners as well as a trend for fewer hospital admissions for respiratory conditions." (HowdenChapman, et al., 2007, p. I). 
Research has found that although the standard upgrade package proposed for New Zealand homes (discussed in chapter 1.6) can to some extent raise indoor temperatures, and reduce health issues across the country, these measures alone cannot raise temperatures in homes in the cooler parts of New Zealand above those recommended by the WHO, and hence will not significantly reduce fuel poverty all over the country (Callau \& Lloyd, 20I0).

The New Zealand building regulations, then New Zealand Standard NZS 1900, first mentioned energy efficiency in their fifth amendment in 1977 but it was not until the Building act of 1991 and the development of clause HI - Energy Efficiency that the New Zealand Building Code had a performance based energy use component. Even then energy efficiency clause, $\mathrm{HI}$ did not come into effect until January 1993.

For the years between 1977 and 199I the following clause governed the energy performance of NZ homes:

\section{"4.26 Thermal insulation}

4.26.I Every residential building shall have thermal insulation properties approved as adequate to prevent an excessive requirement for space heating that utilizes energy from a public electricity supply, from any fuel, or from any other depletable energy source.

4.26.2 A residential building that complies with the requirements of NZS $4218 p^{*}$ in accordance with NZS 42 I4* shall be approved as complying with the requirements of 4.26.I." (New Zealand Standard Model Building Bylaw, 1977)

As a prescriptive code clause 4.26 gave no minimum level of insulation required for compliance and left this open to interpretation. However, it still forms the basis of the standards used today, with the highlighting of thermal insulation (rather than, say, passive solar design and associated energy storage in mass) as a primary means of reducing energy use in buildings.

With over $60 \%$ of New Zealand's current housing stock at the end of 2009 being pre 1978 (Beacon Pathway Limited, 2009), and therefore, pre mandatory insulation of the envelope and with no standard of compliance (other than structural and sanitary) for existing housing to be declared habitable when they are sold as happens in other places such as the UK (Energy Key, 2007). It is clear from the evidence above that measures must be taken to improve the existing housing stock as well as to provide high quality new homes. Not only must New Zealand housing have acceptable comfort and health levels, but these must also be achieved and maintained by sustainable measures, as it is no longer possible to rely on the use of fossil fuels long term to supply the necessary heating energy. 
While New Zealand likes to promote itself as 'Clean and Green' and lifestyle oriented, it is falling behind most other OECD countries in terms of residential living conditions. Whether this is because, for the most part, a moderate climate (The World Factbook, N.d.) with high winter sunshine hours (Mackintosh, 200I) allows people to cope with the winters and accept being cold at night, or because it is part of being a New Zealander to be 'cold' (Cupples, Guyatt V, \& Pearce, 2007 ) is debatable. However, by not raising standards and not providing assistance where needed to meet internationally accepted standards, as a national community these low standards are being deemed to be acceptable.

Globally recognition of the importance of the role of the building industry in sustainability is increasing, especially in terms of much improved thermal performance of buildings, as outlined below.

- The UK has legislated for enforceable 34\% reductions in carbon emissions by 2020 in which the role of building stock is well recognised. The building code has 'locked in' the following progressive intentions in housing performance

- All new homes to be carbon zero by 2016

- All new schools to be carbon zero by 2016

- All new public sector buildings to be carbon zero by 2018

- All new non-domestic buildings to be carbon zero by 2019

The US is pushing change more through rhetoric than legislation, offering significant incentives as discussed in chapter 2.8 though the roles of Federal versus state Government creates complications. The strong messages of the sustainable building movement and visible signs of global warming are also being countered by the 'global financial crisis'.

In Australia where climate change is a more visible problem, causing the greatest droughts and floods seen in 100 years (Australian Government Bureau of Meteorology, 2010), while progression had seemed more advanced, government drive has faltered, with retrofit insulation schemes drying up and the implementation of the Emissions Trading Scheme being delayed.

Germany is discussing a mandate for all new housing built after 2020 to be maintenance free for 100 years. Germany has also introduced the Passiv Haus standards which have been influential across Europe (Econation, 20I0).

The French building code equivalent requires all buildings built after 2012 to produce more energy than they consume (Burghout, 20I0). 
While typically buildings are still being designed to meet the building code requirements of their region, higher standard building initiatives look to "challenge designers to go beyond the codes to improve overall building performance and minimize life-cycle environmental impact and costs" (Gowri, 2004, p. 56). Originally conceived as an objective benchmark by which owners wanting to achieve a higher standard could communicate their efforts, rating systems have the potential to promote dialogue and transform market expectation of sustainability as an integral part of the construction process. The international multitude of emerging rating systems can be daunting and comparisons between them can be difficult "....some environmental criteria related to resource use and loadings can be readily reconfigured to acknowledge different regional and geographical contexts, many others cannot. All assessment tools carry the values and priorities of their authors, either implicitly or explicitly, and importing them from one circumstance to another or, indeed, developing a standardized universally applicable method, is now recognized as problematic" (Cole, 2005, p. 3). However, rating tools can be a means of helping new materials and products to spread through a market. It was noted earlier that the NZi3 building in Christchurch was able to gain an extra point in the New Zealand Green Star rating systems because of the use of PCM materials.

First generation assessment tools include;

BREEAM - The Building Research Establishment Environmental Assessment Method is the earliest building rating system for environmental performance assessment and was developed by the British Research Establishment in 1990 (BREEAM, 2009).

GBTool/SBTool - The Green Building Tool, developed by the Green Building Challenge, is a collaborative effort of more than 20 countries committed to developing a global standard for environmental assessment, with the first draft of the assessment framework being released in 1998 (iiSBE, 2009).

LEED - Leadership in Energy and Environmental Design is a rating system developed by the U.S. Green Building Council (USGBC), which has a market-driven strategy to accelerate the adoption of green building practices. Version 2.0 was released in 2000 (U.S. Green Building Council, 2010).

These three tools "differ in terminologies, structure, performance assessment methods, relative importance of environmental performance categories and documentation requirements for certification" (Gowri, 2004, p. 57) but all have been used as a base for developing new systems for other countries, including those discussed below.

Recent Assessment tools include; 
CASBEE -Comprehensive Assessment for Building Environmental Efficiency in Japan (Japan Sustainable Building Consortium (JSBC), 2006 ).

SBAT -Sustainable Building Assessment tool in South Africa (The Council for Scientific and Industrial Research (CSIR), 2008).

SPeAR - Sustainable Performance Assessment Scheme, project assessment methodology with Ove Arup's consultancy (Arup, 20I0).

CEPAS - Comprehensive Environmental Performance Assessment Scheme, the proposed assessment tool in Hong Kong (Buildings Department, 2009).

Green Globes - a building environmental design and management tool delivering an online assessment protocol, rating system and guidance for green building design, operation and management in Canada and North America. Green Globes is based on BREEAM (Green Globes, N.d.).

These more recent tools "still employ several of the scoring characteristics of earlier systems, they collectively suggest a transition toward a generation of tools that may enable assessment of the extent to which buildings can contribute to supporting sustainable patterns of living” (Cole, 2005, p. 3).

New Zealand's primary rating system, Green Star, "is a comprehensive, national, voluntary environmental rating scheme that evaluates the environmental attributes and performance of New Zealand's buildings using a suit of rating tool kits developed to be applicable to each building type and function." (New Zealand Green Building Council, N.d.) Developed by the New Zealand Green Building Council (NZGBC) in consultation and collaboration with the building industry, it uses an integrated approach which has been trialled in New Zealand and internationally. A cross-industry working group was formed which met over a number of months to develop the tool and this approach has proven to be vital to the overall success and market uptake of the resulting tool. A pilot version of the tool was then released for public comment and feedback, this feedback was fully reviewed by the NZGBC and incorporated into the tool under the guidance of the working group. A summary of responses to feedback was published prior to the launch of the final tool, a process that took some time. Currently Green star has tools for a number of different categories of commercial buildings, such as offices, industrial and education, but is not applied to houses. Most other rating systems have categories that deal with different building types e.g. LEED (U.S. Green Building Council, 2010) and most do include housing. No rating tools specifically encourage the use of PCMs but rather such tools allow designers to make buildings that achieve pre-set targets for building performance. 


\subsection{Commercial Buildings}

Like New Zealand houses, commercial buildings have only been regulated for energy use in recent years. In 1996 a new compliance document for energy use in large non-residential buildings was created entitled NZS 4243: Energy Efficiency - Large Building Envelopes. This new code provided an acceptable standard for the insulation of the envelope of the building which differed from that of residential buildings but also made provision for the energy used to meet lighting requirements to be assessed and controlled. This was the first initiative in New Zealand to take into account building services other than the thermal environment (Cory, 2008).

To date there had been no published comprehensive list of commercial buildings in New Zealand, making it difficult to gain accurate research into the quality and efficiency of non-residential building stock or the changes to it that might have resulted from the introduction of the new standard or the Green Star rating tool. The commissioning of the Building Energy End-use Study (BEES) funded by BRANZ, the Foundation for Research, Science and Technology, the Department of Building and Housing, and EECA has sought to change this.

Understanding how energy and water resources are used in today's commercial buildings will make it possible to use them more efficiently and so enhance New Zealand's sustainability. An efficiency improvement of $10 \%$ would give $\$ 90$ million fuel and at least $\$ 2$ million direct GHG savings per year.

From 2008 and in the subsequent five years the Building Energy End-use Study (BEES) will make the first step toward these efficiency improvements by establishing (a) where and how resources are used, and (b) the determinants of resource use.

The overall results of this project will be:

- Quality data on the uses of energy and water in New Zealand commercial buildings

- An improved basis for policy development and implementation, including any future New Zealand Energy Strategy (NZES) and the National Energy Efficiency and Conservation Strategy (NZNEECS)

- Guidance to create more productive work environments

- Support for reduction of GHG (Kyoto) emissions and adaptation to climate change

- Design and operation guidance to reduce greenhouse gas emissions

- Improved basis for development of the New Zealand Building Code, Standards, Green Star and design guidance

- Improved models for commercial sector energy (including electricity) use 
The BEES research will help understand the relationships between energy and water use in different types of commercial buildings. The results, when they are available in a few years time, will help to indicate the opportunities for improving energy and water use efficiency. The scientific design of this nationwide project has built on the experiences of the Household Energy End-use Project (HEEP) (Isaacs, et al., 2006). The latter was set up to understand energy use in residential buildings. The BEES project also builds on the work of team members in energy studies and audits of commercial buildings.

The data from the monitoring of all fuels (electricity, natural gas, LPG, oil and possibly solid fuel) and water will be combined with end use data (space temperatures, lighting, hot water, and appliances) in an integrated database and analysis system. "This will contribute towards the development of energy efficiency tools and instruments for commercial buildings and their use, in New Zealand and internationally." (BRANZ, 20I0). Years I and 2 of BEES were spent developing an accurate list of commercial buildings from property valuations in order to conduct the rest of the research. This has already provided new knowledge about the non-residential building stock, including size distribution (Isaacs, et al., 2009, p. 24).

As observed above, regulation of new New Zealand commercial buildings is relatively recent, and the Green Star system for assessing environmental impact even more so. This leaves many existing commercial buildings that must, therefore, have minimum environmental standards. In addition, until the recent introduction of the Green Star rating system commercial investors and developers have had little motivation to improve the quality of the building stock they provide leaving in their wake a legacy described, though somewhat unsupported, by Telferyoung in their Wellington Office Survey December 2008 thus;

"Some $8.33 \%$ of the office space is in premium quality buildings of which there are only 9 properties -125 The Terrace, Bowen House, HP Tower, Vodafone on the Quay Tower, State Insurance Tower, Majestic, HSBC Tower, Maritime Building and the new Meridian Building. None of these buildings would, however, measure up to the accepted international premium quality standards".

Perhaps the biggest blow to the New Zealand market is that the new Meridian Building has been included in that list. As the first 5 star Green Star rated building, it is still being heralded as one of the country's best commercial buildings (New Zealand Green Building Council, N.d.).

Although Telferyoung's statement would suggest that it may not be entirely successful, the Green Star scheme, introduced under the previous government, has provided an incentive to improve the quality of New Zealand's buildings and to do so in a sustainable way. Helen Clark's government's commitment to lowering the nation's energy use and providing healthier work spaces for its 
employees through paying a premium rental to do so, paved the way for new large scale, low energy developments (Ministry for the Environment, 2005) (Fullbrook, 2007) (eCubed Building Workshop Ltd, 2008). The Green Star system provides a better than minimum rating tool that drives market competition to be the best and greenest, as a competitive edge in a market for "Prospectors" (Crompton, 2008) and as recognition for people who genuinely want to improve the quality of New Zealand's buildings, if they are prepared to pay for the rating process. It is this market, therefore, that perhaps offers the best place for the introduction of an expensive energy saving technology such as PCM products.

\subsection{History of Office Design}

From the Taylorist ideal ${ }^{4}$ that emerged in the wake of the industrial revolution (Forty, 1986), that efficiency in the production of goods and services was needed, and with the rapid onset of mass production, the North American model of the office building was born. This model broadly revolved around an open space within which the many desks for clerks and typists were arranged in rows (see Figure 2.6). In the early 19th century a hierarchical structure was not only seen as something necessary to form an operational working system but also as something that should be clearly displayed to keep everybody in their place. One of the most visible ways to achieve this hierarchical order was with space. Three spatial factors determined each office worker's importance, the amount of personal space, whether it was enclosed by walls, and proximity to windows. This hierarchy determined the general layout of most office buildings, often creating cellular offices of varying sizes around the perimeter of the building, with the open plan 'hub' for the main body of workers in the windowless, or near windowless, interior.

\footnotetext{
${ }^{4}$ Frederick Taylor advocated The Principles Scientific Management. From the 1880s Taylor studied factory work and applied the art of the assembly line to the office, dividing the labour process into stages, minimising wasted movements and perfecting the handling of a single task.
} 


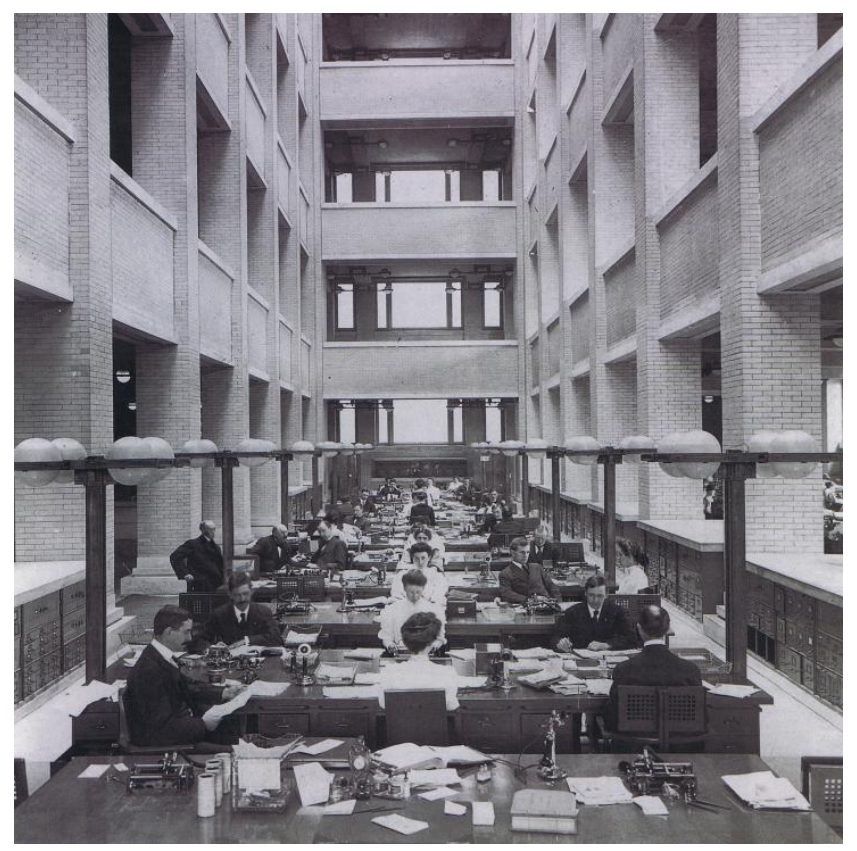

Figure 2.6 - The Larkin Building, Buffalo, New York, I904 (Duffy, I997, p. 20)

With the coming of the age of political correctness in the latter part of the $20^{\text {th }}$ century and a new found modesty about an individual's position in the firm and the empowerment of workers, office spatial hierarchy has changed. Another influential factor has been the increased development of ergonomics", a field born "during the second war, when for the first time, technology and the human sciences were systematically applied in a co-ordinated manner" (Dul \& Weerdmeester, 1993). These ideas have since been extended with the dawn of the information age and introduction of personal computers, as well as an awareness of the value of workplace satisfaction (Freeman, 1978). With some exceptions (see Figure 2.7), views and natural light have been given to the mass of workers and most low and middle level managers (and in some cases top executives) have left the security of separate offices in favour of camaraderie and better working relationships by moving their desks into the main shared space (see Figure 2.8). However, it may be this shift is not always driven by such intentions, but perhaps more often by economics, as fewer walls and less personal space mean a lower building costs and hence a lower rent.

\footnotetext{
5 Ergonomics is the study of human interaction with the tools, technology (hardware/software), the work process, and the environment in which people function. The goal is to fit the job to the person. Ergonomics recognizes the capabilities, differences, and limitations of individuals, and adjusts the work tools, work process, or work environment accordingly (Lawrence Berkeley National Laboratory, 2009).
} 


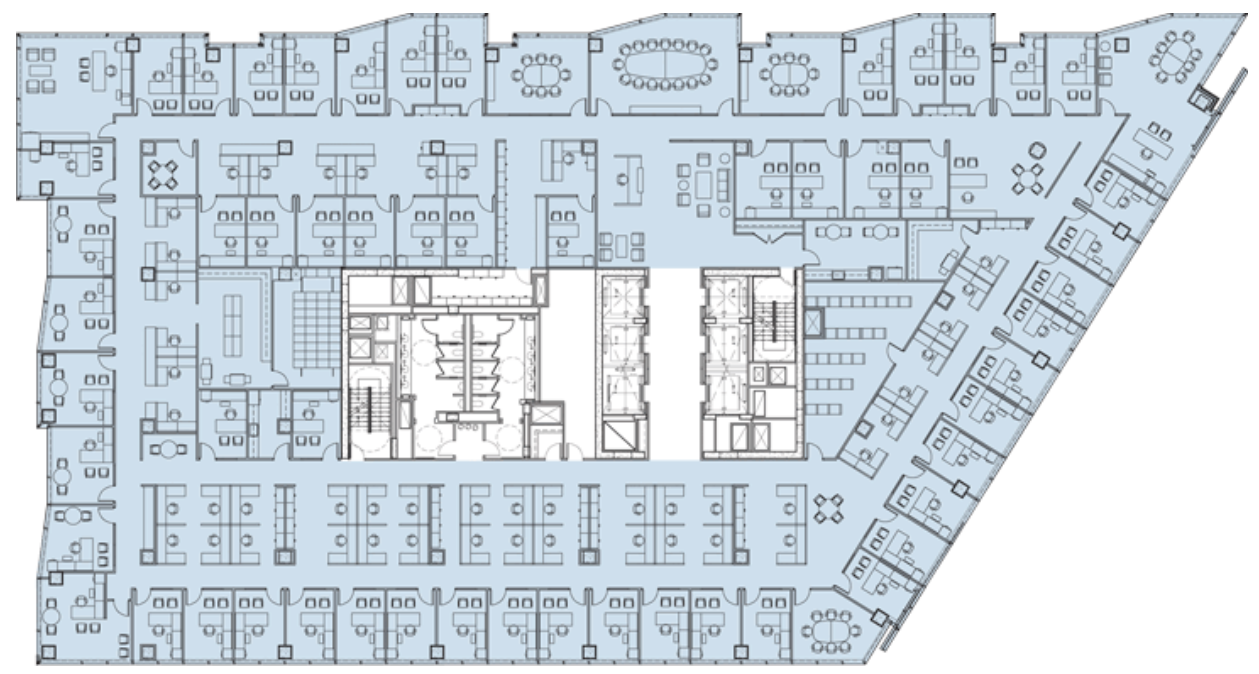

Figure 2.7 - Cellular perimeter office design, The Plaza On K, Washington, DC (Transwestern, 2008)
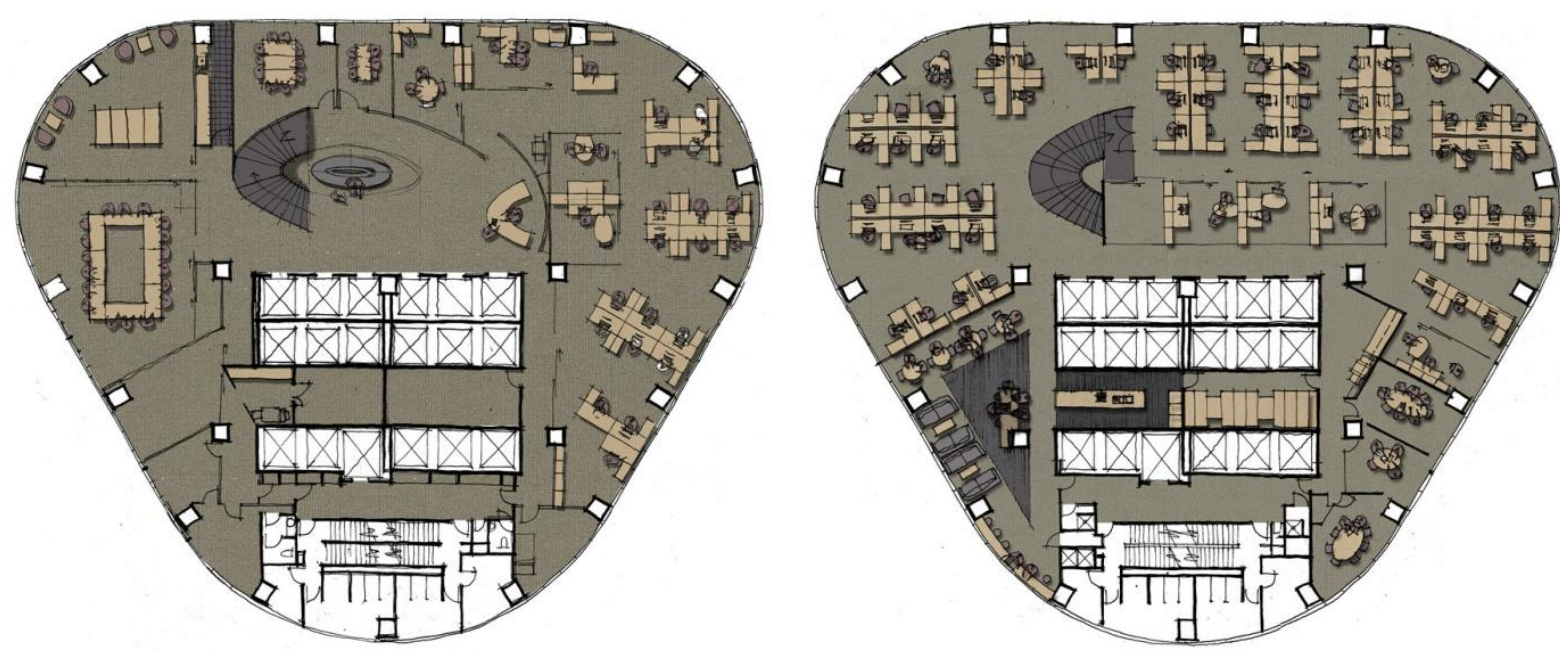

Figure 2.8 - Open-plan office design, levels I 4 and II 5 Mighty River power (Inside Limited, 2007)

Although today Taylor's methods of 'Scientific management' are seen as archaic and might now be referred to with distaste as a human version of battery farming, in most of the industrialised world organisations seem strangely attached to many of the forms and techniques for constructing the buildings and spaces of the past to house the multitude of office based workers today. Today in the interest of 'good human resource management' and employee morale, organisations take great pains to consider and record the views and desires of their employees (creating a new office based industry of Workplace Performance Strategy). Unfortunately there is very little recorded of the working lives or opinions of office workers before the 20th century (Duffy, 1997) so little historical comparison can be drawn about employee satisfaction, perceived environmental conditions or workplace expectations. 
While so blatant and honest an expression of the ranking and functioning of the human resources was common, the functioning of buildings was not so clearly expressed, with the omission of any tools for user awareness or user control over the internal environment. Reyner Banham boldly discusses this in 1969, referencing the 196I Richards Memorial Laboratories in Philadelphia by Louis Kahn (Banham, 1969, pp. 12-13);

"By giving monumental external bulk to the accommodations for mechanical services, Kahn forced architectural writers to attend to this topic in a way that no recent innovation in history had done. No matter how profound the alterations wrought in architecture by the electric lamp, or the suspended ceiling (to cite two major instances of revolutionary inventions), the fact that these alterations were not visible in outward form has denied them, so far, a place in the history of architecture."

Banham furthers this discussion by pointing out the lack of attention given to the way commercial buildings function internally "... the mechanical environment controls are the most obvious and spectacularly important, both as a manifestation of changed expectations and as an irrevocable modification to the ancient primacy of structures, yet are the least studied."

The sheer size (height and depth) of the 'new' style of office building drove the invention of climate control, but this was not without its problems. Due to the vast size and weight of the machinery required there was no option but to accommodate it in the basement of such buildings. This meant that massive extract and exhaust ducts were required to travel the full height of the structure which, along with elevator shafts, would create a thermal siphon effect, drawing cold air in though any openings on the lower levels and ejecting the warmed air up through the shafts. This created not only thermal discomfort but would whisk papers from decks and draw in bad weather and dirt at street level. The solution to this problem was the completion of the hermetically sealed envelope with the re-invention of the revolving door6 (Banham, 1969, pp. 71-74). Banham also points to other innovations that are now taken for granted, but without the invention of which the office tower could never have existed, like the flushing W.C.

In contrast to the North American model of building (also adopted in New Zealand), the Northern European model was less influenced by the Taylorist movement. Like any theory of evolution, however, the evolution of the office is complex. Some Northern European cities, like those of Germany, The Netherlands and Scandinavia, but to a lesser extent those of the UK and France, were more well established in terms of the corporate boom and by the middle of the $20^{\text {th }}$ century were

\footnotetext{
${ }^{6}$ The revolving door was first patented in $188 \mathrm{I}$ by $\mathrm{H}$. Bockhacker of Berlin for "Tür ohne Luftzug" or "Door without draft of air", and soon thereafter in the U.S. in 1888 by Theophilus Van Kannel of Philadelphia for a "Storm-Door Structure".
} 
already exhibiting an office building style of their own. This meant these organisations were less swayed to adopt the modern high rises of their American counter parts. In addition to commitment to their stylistic heritage, Northern European businesses are, even today, more likely to be owner occupiers, borrowing money directly from the bank to build new offices (Duffy, 1997), rather than renting space, as happens in the developer dominated American market. Also needing to be considered in the many factors that drive the difference in office models is that Workers' Councils in Germany, The Netherlands and Scandinavia have long held the right to negotiate the quality of their working environment with their employers (Duffy, 1997, p. 34).

While the North American model is flexible, allowing the design to be adapted to the different needs of different organisations (so long as these needs fit within a grid) their service spaces - bathrooms, circulation spaces, lobbies and stairs - tend to be minimised in order to maximise the rental area and profit for the developer (Vale \& Vale, 1991). This is also true of other aspects conceived as 'construction extras', such as mass that may aid reduced energy usage for heating and cooling, or having a reduced site coverage through a smaller footprint to allow for greater solar gain. These aspects are described by Duffy (Duffy, 1988, p. 42) as “...tradable commodities at worst and construction feats at best. What they definitely are not is well worked out responses to the changing needs of modern organisations and modern office workers. Instead they represent a vision of office work (gangs of under-paid and under-privileged clerks) which is almost a century old."

In contrast the Northern European office building (such as the NMB Bank seen below in Figure 2.9), built directly for the organisation that will occupy it, reflects the needs of that organisation and what it can afford. This method has the advantage of removing the profit-skimming developer from the process, leaving the organisation to get more value for money in its building as any capital augmentation from the development returns to the organisation.

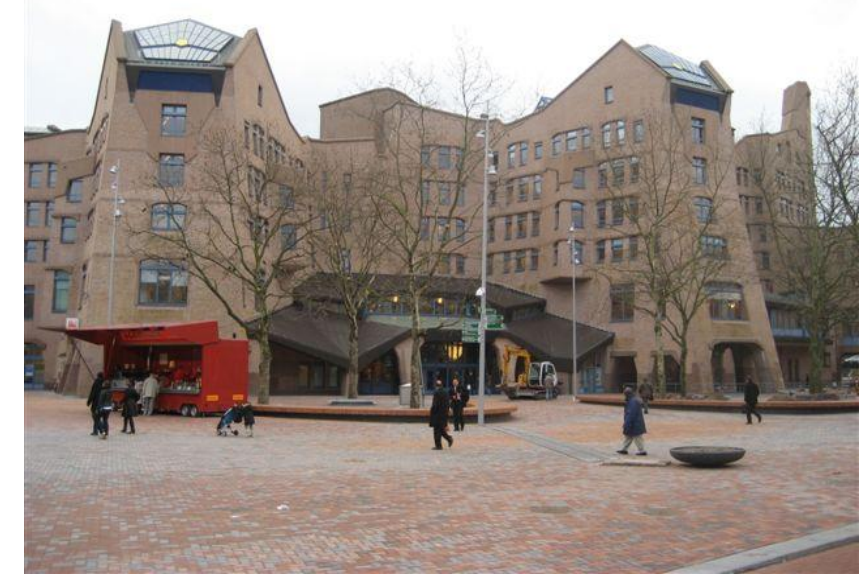

Figure 2.9 - NMB, Amsterdam. Purpose built, low energy, high mass, Northern European office building (www.tonyparr.nl/) 
With the introduction of the first personal computers the size of personal workstations grew, going from a surface for letter sized paper, writing equipment, and possibly a typewriter or adding machine and centralised paper storage to a desk top capable of holding a somewhat space consuming PC. This created the need to move from rectangular desks to the corner variety to allow for the depth for accommodating cathode ray tube (CRT) monitors and keyboards (see Figure 2.10). Furniture screens were also needed to disguise the myriad of electronic cables and backs of the monitors (see Figure 2.II). Although the evolution the liquid crystal display (LCD) flat screen monitor, wireless technology and the paperless office (less paper, rather than no paper) have, to an extent, removed the need for these items and simple rectangular desks would again make more sense, the general population of office dwellers now seem wed to their large, space defining, corner desks and pin board screens (see Figure 2.12 and Figure 2.13).

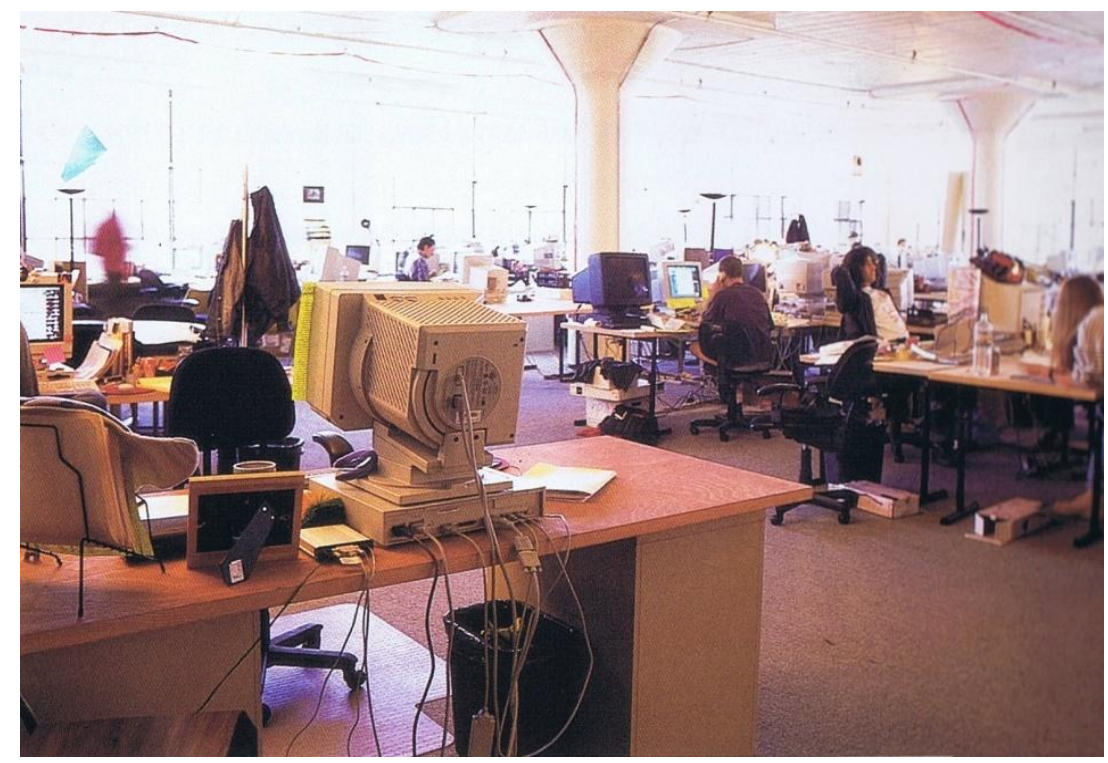

Figure 2.I 0 - CRT Monitors in use; no screens to disguise cables (Duffy F. , I997, p. I0)

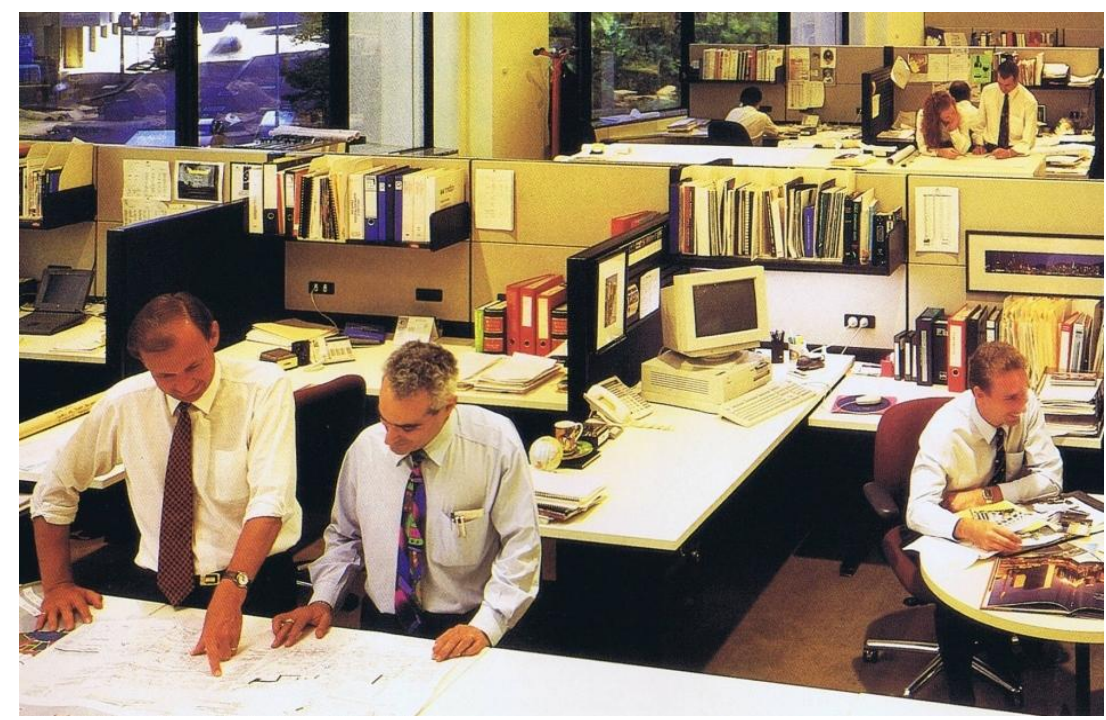

Figure 2. I I - CRT Monitors in use with screens (Duffy F. , | 997, p. I 84) 


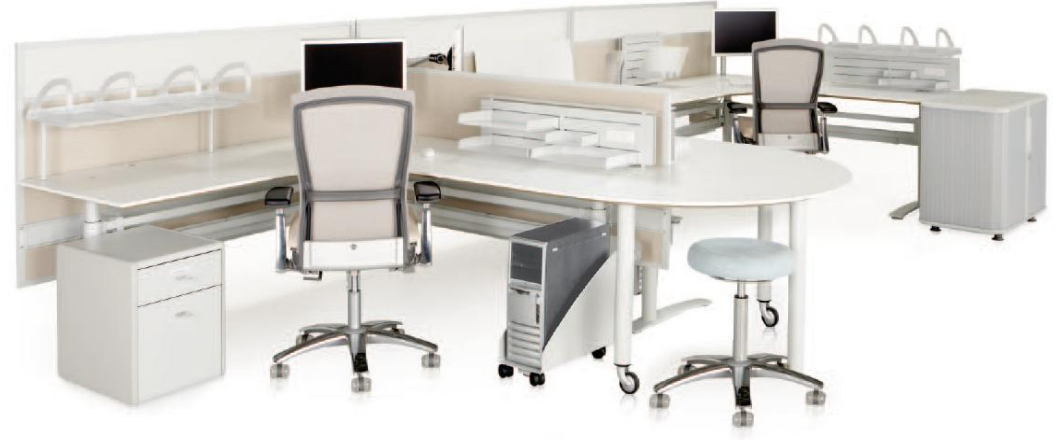

Figure 2.I2 - Corner desk with LCD monitor (Formway Furniture Limited, N.d.)

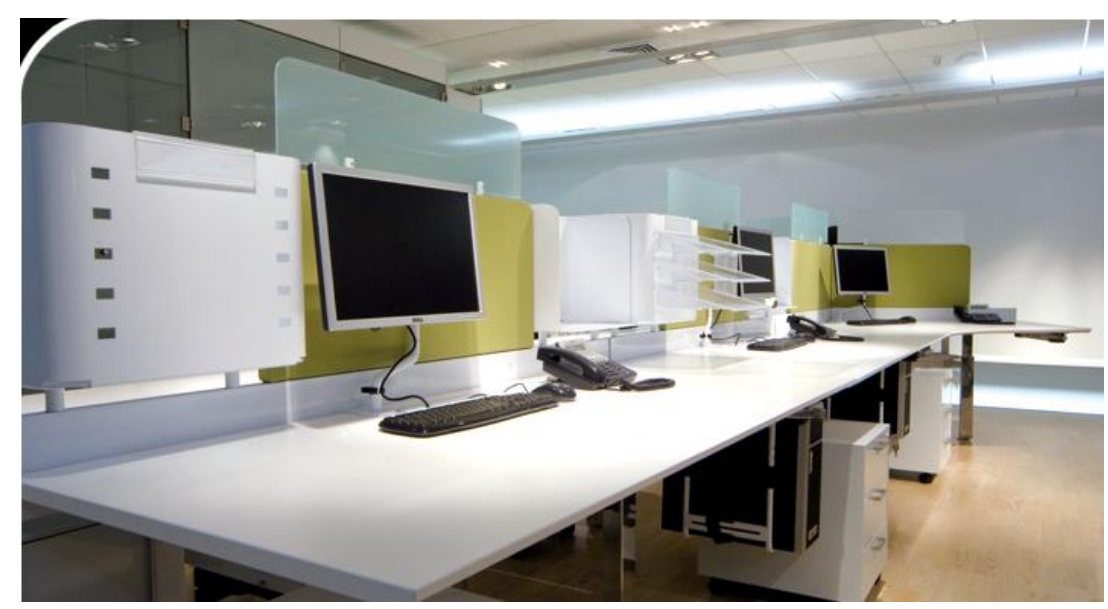

Figure 2.I 3 - Straight desk with LCD monitors (Aspect Furniture Limited, 20 I 0)

Further to creating higher spatial demands, the addition of personal computers in the working office also put greater pressure on cooling and ventilation systems. The heat output of computers matches the energy input, and the table below shows energy use/heat output per computer based on looking at the manufacturers' attributes of various models.

\begin{tabular}{|c|c|c|c|}
\hline & \multicolumn{3}{|c|}{ Energy Usage (Watts) } \\
\hline & Low & Mean & High \\
\hline \multicolumn{4}{|l|}{ Desktop Computer Active } \\
\hline Desktop Screensaver on & & 15 & 250 \\
\hline \multicolumn{4}{|l|}{ Desktop on Standby/Sleep } \\
\hline \multicolumn{4}{|l|}{ Laptop } \\
\hline \multicolumn{4}{|l|}{ 17" CRT Monitor } \\
\hline \multicolumn{4}{|l|}{20 -24" LCD Monitor } \\
\hline \multicolumn{4}{|l|}{ Sleeping monitor dark screen } \\
\hline Monitor switched off & & & 10 \\
\hline
\end{tabular}

Table 2.I - Personal computer energy use (Bluejay, 20 | 0)

As technology improves the energy input, and therefore heat output lowers. The shift from a CRT monitor using 80 Watts, typical just a few years ago, to an energy efficient LCD can easily halve the 
monitor power usage. A shift from a desktop plus monitor to laptop has the potential to reduce usage to under $20 \%$ of the original (Ryu, 2010), provided the rebound effect (discussed in chapter 2.3 above) and increased use of technological devices do not negate the saving.

The 'new' model of office culture seeks to remove the traditional notion of one person at one desk between the hours of 9-5, and the idea that all tasks and all people can be accommodated by a single solution. Instead the new office identifies the different processes involved in different tasks and utilises evolving technology and new methods of defining working space to facilitate a better working environment and higher production. Duffy's analogy of hives, cells, dens and clubs outlines four types of office work. His analysis illustrates the scale of autonomous versus interactive work and describes how different organisations have various proportions of the types of work and how those proportions have changed over time.

The Hive - This scenario is characterised by individual, routine-process work with low levels of interaction and low levels of autonomy. It is typified by shift or nine to five workers often in uniform settings, in open-plan space that is screened but impersonal.

The Cell - Cell offices accommodate individuals undergoing concentrated work with little interaction. Highly autonomous people occupy them in an intermittent, irregular pattern with extended working days and often work elsewhere at least some of the time.

The Den - The den is associated with group work, typically highly interactive but not necessarily highly autonomous. Usually it consists of simple settings arranged in an open-plan environment or in group rooms. It is assumed that workers each occupy their own desk and also have access to meeting rooms and communal utilities.

The Club - This scenario is for knowledge work that transcends data-handling, being highly autonomous and highly interactive. The pattern of occupancy tends to be intermittent over an extended working day, with occupation on an as needed basis.

However, despite the thought that has gone into new ways of working in the office, no consideration has been given to matching these with appropriate indoor conditions, as Duffy has observed. "Conventional office buildings, especially in North America, are usually designed to be hermetically sealed. No one can open a window. The assumptions that lie behind this bizarre practice are that energy is cheap, that the architect's and environmental designer's job is to create a uniformly perfect interior climate that will satisfy everyone; and that the best ways to do this are to screen out the effects of unpredictable changes in the exterior climate and stamp out the possibility of any climate-modifying behaviour on the part of the occupants. Even differences between night and day are, for all practical purposes, ignored - what 
matters is the provision of constant internal conditions. In this environmentally conscious era such mechanistic, narrow-minded - and fundamentally lazy - assumptions are intolerable.” (Duffy, 1997)

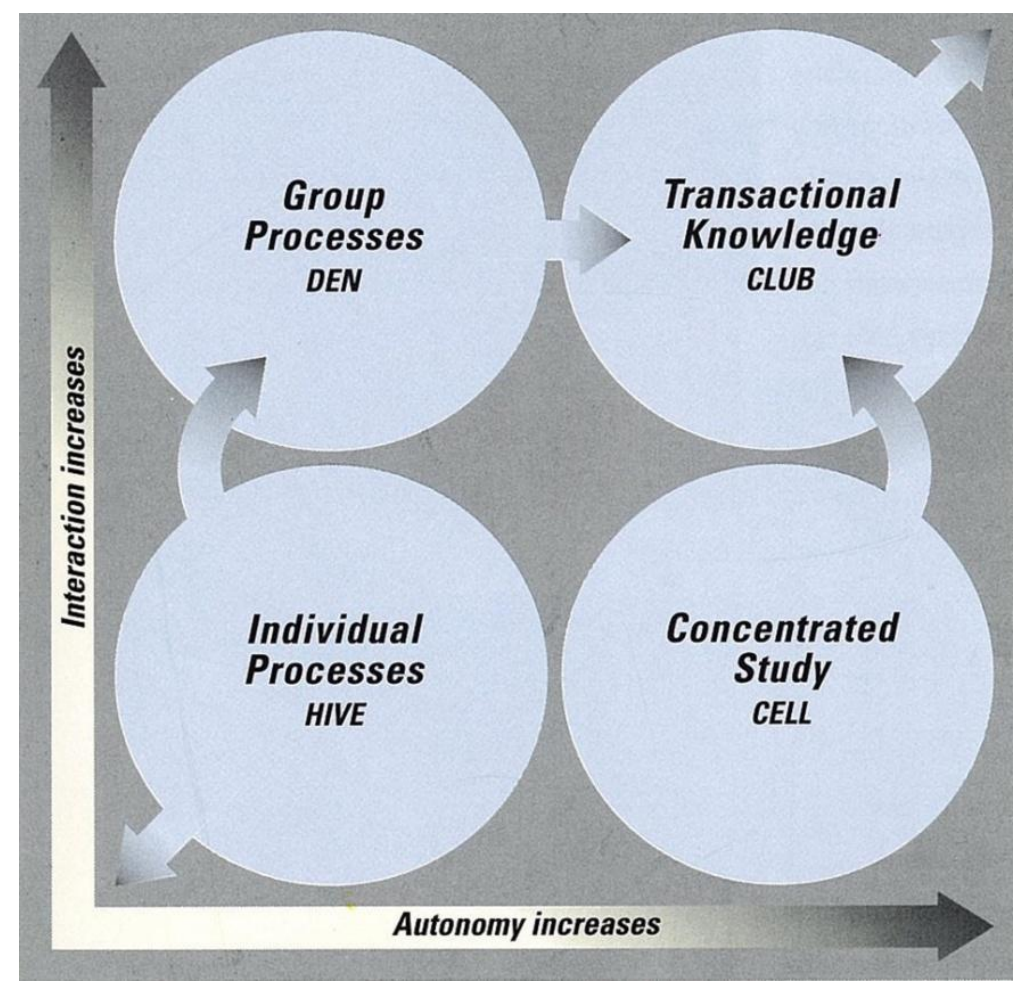

2.14 - Duffy's diagram of organisational types (Duffy F. , 1997)

What this means altogether is that for the modern office interior, especially in New Zealand where the US developer model is followed, when it comes to phase change materials, there are few walls to put them on. In addition, the flexibility required of the North American style of office to move between the different scenarios demanded by the different tenants in the life of a building means a level of disposability is needed in the internal walls that are installed, so again there is nowhere obvious to put the phase change materials. In fact, they are better suited to use in purpose designed, higher value offices as found in parts of Europe and this may be a reason (apart from cost) why more examples of their use are found in Europe than in New Zealand. It has been recognised that in the making of low energy and sustainable buildings a multi-disciplinary approach is vital for a successful outcome (U.S Department of Energy, 2009) but for the successful integration of PCMs into such buildings the team will need to include people with knowledge of the way the office works and how this might change over time.

\subsection{Subsidies and Incentives}

As mentioned above in chapter 2.6, many governments or councils offer subsidy or incentive based initiatives to increase the uptake of energy saving products. By investing up front to have energy 
saving schemes installed, the country or (Shirkey, 2005) region assist their constituents in lowering their individual use of resources, lowering the pressure on the resources of the region and working toward a greater good.

There are many different types of incentives offered by different countries, states, or councils around the world to encourage reduction in local energy use and the use of renewable energy sources. Recognition is given to technologies including insulation, solar hot water heating, photovoltaic energy generation, and wind generation but not yet to PCMs as a separate product. The levels of incentives offered in different regions vary due to many different factors, and shifting local pressures. Incentive schemes include the following;

Net Metering / Buy Back - This is where excess electricity generated by the customer from installing renewable energy generating devices can be fed back into the grid and the cost offset against any electricity used from the grid.

Tax Incentives - These fall into three categories; personal tax, sales tax incentives, and property tax incentives.

Rebate Programmes - These are where a percentage of total cost of the supply and installation of the renewable energy system or energy upgrade is rebated by the state, local government or utility provider.

Low interest loans - By offering long term, low interest loans private companies or governments offset the upfront equipment and installation cost of the renewable energy source or energy upgrade with the ongoing savings made.

Public benefit funds - These are usually funded by a surcharge on the local utility supply. Public benefit funds are used to fund rebate, loan and education programmes ('Anna', 2008).

Energy Rating Schemes - These do not offer any direct monetary benefit, but it is suggested that high rating energy efficient homes and buildings sell for higher prices and are easier to tenant at higher rents (Lee, 2008).

Net Metering / Buy Back only applies to renewable energy generating systems and is where excess electricity generated by the customer can be fed back into the grid and the cost offset against any electricity used from the grid. Sometimes the customer is paid extra by the power company for this surplus energy. Net metering eliminates the need for onsite battery electrical energy storage but allows for times of high and low energy collection to be evened out by use of the grid. This necessitates maintaining a connection to the grid, and paying the connection fee and in most 
instances the supply and installation cost of approved metering equipment in addition to the cost of the renewable energy source. There are also certain protocols that have to be worked through in setting up a grid-linked installation to ensure the safety of those working on the lines. The price at which the electricity is bought back, as with the cost at which is supplied, varies throughout regions and supply companies (Fowler, 2010), but in some areas is regulated (Richards, 2009). These schemes may also dictate the size of the system in terms of rated power (Australian Gas and Power, 2010). Such schemes are available in New Zealand but vary with the electricity retailer as to what is entailed.

Tax Incentives fall into three categories; personal tax incentives where the cost of the supply and installation of the renewable energy source is offset against personal income tax; sales tax incentives where the cost of the supply and installation of the renewable energy source is exempt from sales tax; and property tax incentives where the value of the supply and installation of the renewable energy source is excluded from an individual's property for taxation purposes. Personal tax incentives differ in the percentage of total cost to be credited and usually have a maximum currency value. There are no schemes like this in New Zealand.

Rebate Programmes are where a percentage of total cost of the supply and installation of the renewable energy system or energy upgrade programme is rebated by the state, local government or utility provider. The percentage returned varies and rebate programmes usually have a maximum currency value (Bloch, 2008). The current New Zealand home owners insulation and solar water heating programmes are rebate schemes as the government picks up part of the original cost of installation.

Low interest loans that are long term allow private companies or governments to offset the upfront equipment and installation cost of the renewable energy source with the ongoing savings made. This effectively makes the installation free for the user by keeping the monthly repayments the same as the previous energy bill and the difference in the power saving going to pay off the loan. Once the loan is repaid (3-8 years) the household generated energy is really 'free' for the remaining life of the system (20-35 years) (Shirkey, 2005). These schemes take advantage of the low maintenance costs of renewable energy systems. There are no schemes of this type in New Zealand.

Public benefit funds are usually funded by a surcharge on the local utility supply. Public benefit funds are used to fund rebate, loan and education programmes. ('Anna', 2008). The nearest to this type of scheme in New Zealand is Meridian Energy's supply of guaranteed renewable electricity to consumers. This costs more but the surcharge is used by the company to fund the installation of more renewable energy generating equipment, such as wind farms. 
Although energy rating schemes do not offer any direct monetary benefit high rating energy efficient homes and building anecdotally sell for higher prices and are easier to tenant at higher rents (Lee, 2008). One of the shortfalls of rating schemes is the lack of an international standard. In New Zealand the rating tool for 'green buildings' is Green Star. This is administered by the non-profit industry organisation The New Zealand Green Building Council, or NZGBC, which rate buildings based on different environmental factors, many of which have their roots in energy efficiency. New Zealand also has a Home energy rating scheme (Hers) run by Energywise, which is part of the Energy Efficiency and Conservation Authority or EECA, which rates the energy efficiency performance of a home but this is not yet in general use. EECA also administer Energy Star which rates the energy efficiency of appliances. While both Green Star and Energy Star have been based on international models weightings are adjusted to suit New Zealand's climate and resources and proximity to off shore resources. As adjustments are made the tool evolves and while deemed to be 'in line with' others ratings it cannot be directly compared.

International energy efficiency rating tools include;

House Energy Rating - Australia

National Home Energy Rating Scheme (NHER) - UK

EnerGuide - Canada

Home Energy Rating -USA

One of the problematic aspects of building rating schemes is that almost all of them are based solely on design and not on performance. The cost and length of time involved in effectively commissioning buildings post occupancy (and post expenditure) leaves buildings largely untested to see if they meet the performance levels predicated, and rated, by their design. The table below sets out the types of grants for renewable energy installations and energy upgrades available in New Zealand. 


\begin{tabular}{|l|l|l|l|}
\hline Incentive & Amount of Incentive & Average Cost of Initiative & Supplier \\
\hline Home Insulation Grant & $33 \%-60 \%$ of cost $<\$ 1,300.00$ & $\$ 3,500$ & EECA \\
\hline $\begin{array}{l}\text { Clean Heating Grant } \\
\text { Solar Water Heating Grant }\end{array}$ & $\$ 500$ or $\$ 1200$ & $\$ 3,000$ & EECA \\
\hline $\begin{array}{l}\text { Heat Pump Water Heating } \\
\text { Grant }\end{array}$ & $<\$ 1,000$ & $\$ 8,000-\$ 10,000$ & EECA \\
\hline Sustainable Energy Grant & $<\$ 1,000$ & & EECA \\
\hline Net Metering & $20 \mathrm{c} / \mathrm{kW}$ (one to one) & N/A & Wellington City Council \\
\hline Net Metering & $17.3 \mathrm{c} / \mathrm{kW}$ & N/A & Meridian Energy \\
\hline Net Metering & $6-7 \mathrm{c} / \mathrm{kW}$ & N/A & Contact Energy \\
\hline
\end{tabular}

Table 2.2 - Renewable energy source grants available in New Zealand

There are also many incentives offered by non-renewable energy suppliers, and the motivations for these incentives are easy to understand - the company connects a new client who is then obliged to buy their product for a given length of time, if not indefinitely. One such incentive is for natural gas where the cost of installing the gas onto a residential property as far as the gas meter is met by the supplier of the gas line (within certain parameters) on the condition that the occupier installs a gas hot water supply.

Electricity suppliers (some offer at least a partially renewable supply) often offer competitive incentives including gifts, discounted months, different pricing plans, and discounted rates given for dual fuel source supply (i.e. gas and electricity) if people sign up to a particular company.

The motivation for power companies to offer grants for installing renewable energy systems do not seem so obvious, as they are doing themselves out of an ongoing supply customer. However, by promoting net metering or buy-back options, and helping provide the means to install the system through initiatives such as low interest loans, power companies secure their ongoing daily connection fee and reduce their need for expenditure on industrial power generation equipment and maintenance.

All this suggests that if a good energy case can be made for installing PCM products in buildings, ways may be found of reducing the costs through the types of schemes described above, since energy savings are of interest to power company suppliers (as these are cheaper than finding the capital for new generating equipment), councils and the government. However, for this to happen, the savings from use of PCMs need to be clearly documented in real world examples. Only then can 
organisations like EECA, who rely on clear research results for their recommendations to the public and government, champion the use of the products.

\subsection{Precedent Products}

It may be useful to compare the development of PCMs to another product with similar benefits and costs, photovoltaic panels. However, unlike photovoltaic panels which are the easiest way for a household to generate electricity, PCMs have a much cheaper, low-tech alternative-mass. While the heat absorption capacity of $20 \mathrm{~mm}$ PCM plaster is considered to be the equivalent of $200 \mathrm{~mm}$ of concrete (Greifenhagen, 2004), current PCM products are based on paraffin and only have an advantage in situations where lightweight building is the only option, or for upgrading the existing lightweight building stock. Once non petrochemical based PCMs are developed, with the anticipation these will have a lower cost both financially and for the environment, they may be more likely to attract subsidies in the way PVs do. Also unlike PCMs which simply store energy in the form of heat, photovoltaics (PVs) are used for generating electric power using the sun's radiation, and are thus a substitute for other more environmentally costly techniques of electrical power generation. Not unlike PCMs, PVs are often positioned out of sight to get the best location for solar gain and also because they are not generally considered aesthetically pleasing, with the exception of situations described in chapter 2.4. Also like PCMs the cost of PVs is generally far greater than their less environmentally beneficial competitors (conventionally generated electricity). This is shown in table 2.I below, and though the cost of electricity is now higher than it was, the payback period for the cost of installing the technology to make use of the free solar energy is perceived as too long for many potential users (www.solarbuzz.com, 20I0). Despite this, and unlike PCMs, PV production has been doubling every two years since 2002, making it the world's fastest-growing energy technology (Kropp, 2009). However, these figures include PV power stations and use of panels in developing countries where alternative 'on the grid' options are not available and grid connected support programmes in Europe and Japan (IT Power (Australia) Pty Ltd, 2009). Importantly, many countries have introduced financial incentives for the installation of PVs which could account for much of the explosive growth in the industry. These countries include Australia, Germany, Greece, Israel, Japan, Taiwan and several states of the US see table 2.4 below. 


\begin{tabular}{|c|c|c|c|c|c|c|c|c|c|c|c|c|c|}
\hline \multirow{3}{*}{\multicolumn{2}{|c|}{$\begin{array}{l}\text { Module Cost } \\
\$ U S / k W p^{7}\end{array}$}} & \multicolumn{3}{|c|}{ Small $<2 k W$} & \multicolumn{3}{|c|}{ Medium 2 - I0kW } & \multicolumn{3}{|c|}{ Large $>100 \mathrm{~kW}$} & \multicolumn{3}{|l|}{ Off-grid } \\
\hline & & \multirow{2}{*}{$\begin{array}{l}\text { Module } \\
\%\end{array}$} & \multirow{2}{*}{\multicolumn{2}{|c|}{$\begin{array}{l}\text { System Cost } \\
\$ U S / k W_{p}\end{array}$}} & \multirow{2}{*}{$\begin{array}{l}\text { Module } \\
\%\end{array}$} & \multirow{2}{*}{\multicolumn{2}{|c|}{$\begin{array}{l}\text { System Cost } \\
\$ U S / k W_{p}\end{array}$}} & \multirow{2}{*}{$\begin{array}{l}\text { Module } \\
\%\end{array}$} & \multirow{2}{*}{\multicolumn{2}{|c|}{$\begin{array}{l}\text { System Cost } \\
\$ U S / k W_{p}\end{array}$}} & \multirow{2}{*}{$\begin{array}{l}\text { Module } \\
\%\end{array}$} & \multirow{2}{*}{\multicolumn{2}{|c|}{$\begin{array}{l}\text { System Cost } \\
\$ U S / k W_{p}\end{array}$}} \\
\hline & & & & & & & & & & & & & \\
\hline$\$$ & 5.00 & $65 \%$ & $\$$ & 7.73 & $67 \%$ & $\$$ & 7.42 & $70 \%$ & $\$$ & 7.13 & $40 \%$ & $\$$ & 12.50 \\
\hline$\$$ & 4.00 & $61 \%$ & $\$$ & 6.53 & $65 \%$ & $\$$ & 6.18 & $68 \%$ & $\$$ & 5.87 & $40 \%$ & $\$$ & 10.10 \\
\hline$\$$ & 3.00 & $57 \%$ & $\$$ & 5.27 & $61 \%$ & $\$$ & 4.90 & $65 \%$ & $\$$ & 4.58 & $38 \%$ & $\$$ & 7.95 \\
\hline$\$$ & 2.00 & $51 \%$ & $\$$ & 3.93 & $56 \%$ & $\$$ & 3.55 & $62 \%$ & $\$$ & 3.24 & $33 \%$ & $\$$ & 6.05 \\
\hline$\$$ & 1.00 & $41 \%$ & $\$$ & 2.47 & $48 \%$ & $\$$ & 2.08 & $56 \%$ & $\$$ & 1.80 & $23 \%$ & $\$$ & 4.40 \\
\hline
\end{tabular}

Table 2.3 - Breakdown of PV module and system costs (2008 \$US per kWp) for various PV module costs and different applications (IT Power (Australia) Pty Ltd, 2009)

\begin{tabular}{|c|c|c|}
\hline \multicolumn{3}{|l|}{ Asia/Pacific } \\
\hline February 17,2010 & Israel & $\begin{array}{l}\text { Israel's Minister of National Infrastructure (MNI) authorized the ministry's new policy for up to } \\
50 \mathrm{~kW} \text { size PV installations for residential and small industrial installations. }\end{array}$ \\
\hline July 8, 2009 & Taiwan & $\begin{array}{l}\text { The Taiwan government started several initiatives aimed at supporting the growth of the } \\
\text { domestic green energy industry, which is helping to cut carbon emissions and make better use of } \\
\text { renewable energy. }\end{array}$ \\
\hline June 9, 2009 & Australia & $\begin{array}{l}\text { The Australian Government released the final legislation for the expanded Renewable Energy } \\
\text { Target (RET) which will allow for the creation of new 'Solar Credits' to replace the existing } \\
\text { Solar Homes and Communities Plan (SHCP) from today onwards. }\end{array}$ \\
\hline May 18, 2009 & Australia & $\begin{array}{l}\text { The Rudd Government announced that it is to invest } \$ 4.5 \text { billion in becoming a world leader in } \\
\text { solar power and other clean energy initiatives }\end{array}$ \\
\hline Dec 17, 2008 & Australia & $\begin{array}{l}\text { Treasurer Wayne Swan, Minister for Climate Change Senator Penny Wong and Environment } \\
\text { Peter Garrett have released details on the Government's } 20 \text { per cent Renewable Energy Target } \\
\text { and new 'Solar Credits' as part of Australia's move to a low pollution future. }\end{array}$ \\
\hline Aug 15, 2007 & Australia & $\begin{array}{l}\text { The State Government of South Australia released its solar "feed-in" legislation - which will see } \\
\text { home-owners with solar panels receive double-credit for power they feed into the grid. }\end{array}$ \\
\hline May 2I, 2007 & Australia & $\begin{array}{l}\text { Householders, schools and community organizations planning to take advantage of the Australian } \\
\text { Government's new } \$ 150 \text { million solar power rebate can apply immediately for the increased } \\
\text { rebate. }\end{array}$ \\
\hline Apr 16, 2007 & Australia & $\begin{array}{l}\text { The Australian Government will provide more than } \$ 12 \text { million in funding to support the first } \\
\text { Solar City in central Australia, the Minister for Environment Malcolm Turnbull, and the Minister } \\
\text { for Industry lan Macfarlane, announced today. }\end{array}$ \\
\hline Oct 25, 2006 & Australia & $\begin{array}{l}\text { Federal Treasurer, Peter Costello, and Industry Minister lan Macfarlane today announced the } \\
\text { first two projects under the Australian Government's } A \$ 500 \text { million Low Emissions Technology } \\
\text { Demonstration Fund (LETDF) }\end{array}$ \\
\hline
\end{tabular}

\footnotetext{
${ }^{7}$ The maximum possible output of a photovoltaic solar generator operating under standard conditions is defined as its peak output, measured in watts or kilowatts and stated as either $W_{p}$ or kWp, respectively.
} 


\begin{tabular}{|c|c|c|}
\hline Aug 22, 2006 & Australia & $\begin{array}{l}\text { A renewable energy support program which has provided sustainable power to } 77 \text { small remote } \\
\text { indigenous communities has received a funding boost of } A \$ 1 \text { I million over two years from the } \\
\text { Australian Government. }\end{array}$ \\
\hline \multicolumn{3}{|l|}{ Europe } \\
\hline February I, 2010 & United Kingdom & $\begin{array}{l}\text { Households and communities who install generating technologies such as small wind turbines } \\
\text { and solar panels will from April be entitled to claim payments for the low carbon electricity they } \\
\text { produce. }\end{array}$ \\
\hline June 8, 2009 & Greece & A new incentive program for small rooftop PV systems was introduced in Greece late last week. \\
\hline Jan 20, 2009 & Greece & $\begin{array}{l}\text { A new PV law was introduced in Greece on January I5th } 2009 \text {, amending the legislation } \\
\text { originally voted in mid-2006. }\end{array}$ \\
\hline May 30, 2008 & Germany & $\begin{array}{l}\text { The German government coalition between CDU/CSU (Christian Democratic Union / Christian } \\
\text { Social Union) and SPD (Social Democratic Party) reached agreement in principle on the new } \\
\text { funding terms for photovoltaics. }\end{array}$ \\
\hline May 27, 2008 & Germany & $\begin{array}{l}\text { The Conservative CDU/CSU alliance in the German Bundestag (Lower House of Parliament) has } \\
\text { announced that they want to see a decrease in solar funding by } 2010 \text { of over } 25 \text { percent. }\end{array}$ \\
\hline Dec 6, 2007 & Germany & $\begin{array}{l}\text { The German Cabinet has approved a draft law for the amendment of the Renewable Energy Act } \\
\text { (EEG), the main national funding mechanism that provides market incentives for renewable } \\
\text { energy in Germany. }\end{array}$ \\
\hline \multicolumn{3}{|c|}{ North America } \\
\hline February 8,2010 & United States & $\begin{array}{l}\text { Senator Bernie Sanders (I-VT) and Representative Steve Cohen (D-TN) have introduced the } 10 \\
\text { Million Solar Roofs and I0 Million Gallons of Solar Water Heating Act of } 2010 .\end{array}$ \\
\hline January 8,2010 & United States & $\begin{array}{l}\text { An agreement reached this week between PNM and numerous environmental, renewable energy } \\
\text { and government groups could pave the way for one of the largest-ever expansions of solar } \\
\text { energy in New Mexico. }\end{array}$ \\
\hline January 5,2010 & United States & $\begin{array}{l}\text { Building on the success of the Commonwealth Solar rebate program, which issued awards for } \\
23.5 \text { megawatts of solar power in less than two years, the Patrick-Murray Administration has } \\
\text { unveiled new rebate programs. }\end{array}$ \\
\hline $\begin{array}{l}\text { December 10, } \\
2009\end{array}$ & United States & $\begin{array}{l}\text { The World Bank's Clean Technology Fund (CTF) approved financing of } \$ 750 \text { million last week, } \\
\text { which will mobilize an additional } \$ 4.85 \text { billion from other sources, to accelerate global } \\
\text { deployment of Concentrated Solar Power (CSP). }\end{array}$ \\
\hline October 9, 2009 & United States & $\begin{array}{l}\text { At the opening of the U.S. Department of Energy's Solar Decathlon on the National Mall Energy } \\
\text { Secretary Steven Chu announced up to } \$ 87 \text { million would be made available to support the } \\
\text { development of new solar energy technologies. }\end{array}$ \\
\hline $\begin{array}{l}\text { September 25, } \\
2009\end{array}$ & Canada & $\begin{array}{l}\text { The Government of Ontario has officially launched Canada's first feed-in tariff, a new renewable } \\
\text { energy program established under the landmark Green Energy Act. }\end{array}$ \\
\hline $\begin{array}{l}\text { September 16, } \\
2009\end{array}$ & United States & $\begin{array}{l}\text { Governor Arnold Schwarzenegger signed an Executive Order (EO) directing the California Air } \\
\text { Resources Board (CARB) to adopt regulations increasing California's Renewable Portfolio } \\
\text { Standard (RPS) to } 33 \text { percent by } 2020 \text {. }\end{array}$ \\
\hline $\begin{array}{l}\text { September 14, } \\
2009\end{array}$ & United States & $\begin{array}{l}\text { The } 2009 \text { California legislative session ended on Friday without passing AB } 560 \text { (Skinner), a bill } \\
\text { that would have allowed solar energy customers to continue benefiting from 'net energy } \\
\text { metering'. }\end{array}$ \\
\hline
\end{tabular}




\begin{tabular}{|c|c|c|}
\hline July 30, 2009 & United States & $\begin{array}{l}\text { As part of the New Jersey Board of Public Utilities' effort to support building new solar energy } \\
\text { projects in New Jersey, Atlantic City Electric (ACE) and Jersey Central Power\&Light (JCP\&L) are } \\
\text { conducting a Request for Proposal (RFP) to secure Solar Renewable Energy Certificates (SRECs). }\end{array}$ \\
\hline July 30, 2009 & United States & $\begin{array}{l}\text { U.S. Energy Secretary Steven Chu announced yesterday that the Department of Energy will } \\
\text { provide up to } \$ 30 \text { billion in loan guarantees, depending on the applications and market } \\
\text { conditions, for renewable energy projects. }\end{array}$ \\
\hline July 30, 2009 & United States & $\begin{array}{l}\text { US Department of Energy Secretary Steven Chu announced today the investment of up to } \$ 1 \text { I.8 } \\
\text { million - } \$ 5 \text { million from the American Recovery and Reinvestment Act - for five projects } \\
\text { designed to advance the next stage of development of solar energy grid integration systems } \\
\text { (SEGIS). }\end{array}$ \\
\hline July 29, 2009 & United States & $\begin{array}{l}\text { PSE\&G today received approval from the New Jersey Board of Public Utilities (BPU) to invest } \\
\$ 515 \text { million in } 80 \text { megawatts of solar projects, doubling the state's solar capacity and creating } \\
\text { green jobs. }\end{array}$ \\
\hline July 22, 2009 & United States & $\begin{array}{l}\text { The Sacramento Municipal Utility District has established a feed-in tariff (FIT) effective next } \\
\text { January that streamlines buying electricity fed into its distribution system from eligible generation } \\
\text { units at customer sites. }\end{array}$ \\
\hline July 16, 2009 & United States & $\begin{array}{l}\text { The U.S. Department of Energy will provide up to } \$ 52.5 \text { million to research, develop, and } \\
\text { demonstrate Concentrating Solar Power systems capable of providing low-cost electrical power } \\
\text { both day and night. }\end{array}$ \\
\hline July 9, 2009 & United States & $\begin{array}{l}\text { The U.S. Department of the Treasury and the U.S. Department of Energy today announced an } \\
\text { estimated } \$ 3 \text { billion for the development of renewable energy projects. }\end{array}$ \\
\hline June 29, 2009 & United States & $\begin{array}{l}\text { Under initiatives announced today by Secretary of the Interior Ken Salazar and U.S. Senator } \\
\text { Harry Reid (D-NV), federal agencies will work with western leaders to designate tracts of U.S. } \\
\text { public lands in the West as prime zones for utility-scale solar energy development. }\end{array}$ \\
\hline June 4, 2009 & United States & $\begin{array}{l}\text { Progress Energy has filed a } 10 \text {-year plan with the Florida Public Service Commission this week to } \\
\text { increase the company's existing energy-efficiency goal of } 412 \text { million kilowatt-hours (kWh) by } \\
\text { nearly } 50 \text { percent throughout the course of the plan. }\end{array}$ \\
\hline
\end{tabular}

Table 2.4 - World incentives for renewable energy programmes

Globally PV electricity prices are predicted to reach grid parity in many markets from 20I3, "The UK solar revolution is underway. With the right supply chain in place, I believe that we can achieve grid parity where solar power in homes will cost no more than conventional electricity - as soon as 20 I3" (Solarplaza, 2010).

In New Zealand opportunities for PV installation fall into four general categories;

Solar Farms - Large central generating plant

Medium scale installations - Commercial and light industrial premises for daytime load reduction

Small scale residential - Grid-connected systems providing distributed generation 
Off-grid systems - These systems displace diesel or petrol generators or are used instead of uneconomic remote lines.

Of these, there are examples of the latter three in New Zealand but not the first. There is also a growing market for alternative PV products such as lights for gardens, caravans and boats, and power supplies for boats and caravans, computer charging and for running electric fences.

In New Zealand, although recently the module supply market has opened up to a number of distributors, lowering the supply and installation costs, without the support of government as seen in other countries, and if wholesale electricity prices continue to rise at current rates (see Table 2.5), solar Farms are not expected to be cost effective during the period 2009-2035.

Despite reduced economies of scale, the residential PV market is likely to achieve grid parity faster than other markets due to the higher retail costs of electricity (see Figure 2.15). 


\begin{tabular}{|c|c|c|c|c|c|c|c|c|}
\hline \multirow[b]{2}{*}{$\begin{array}{l}\text { Calendar } \\
\text { Year }\end{array}$} & \multicolumn{4}{|c|}{ cents per kWh } & \multicolumn{4}{|c|}{$\$ / G J$} \\
\hline & $\begin{array}{l}\text { Residential } \\
\text { (Incl GST) }\end{array}$ & $\begin{array}{l}\text { Commercial } \\
\text { (Excl. GST) }\end{array}$ & $\begin{array}{l}\text { Industrial } \\
(\text { Excl. GST) }\end{array}$ & $\begin{array}{l}\text { National } \\
\text { Average }^{2}\end{array}$ & $\begin{array}{l}\text { Residential } \\
\text { (Incl GST) }\end{array}$ & $\begin{array}{l}\text { Commercial } \\
\text { (Excl. GST) }\end{array}$ & $\begin{array}{l}\text { Industrial } \\
\text { (Excl. GST) }\end{array}$ & $\begin{array}{l}\text { National } \\
\text { Average }^{2}\end{array}$ \\
\hline 1974 & 1.15 & 2.08 & 0.90 & 1.20 & 3.20 & 5.77 & 2.50 & 3.34 \\
\hline 1975 & 1.19 & 2.13 & 0.94 & 1.24 & 3.31 & 5.91 & $2.6 I$ & 3.45 \\
\hline 1976 & 1.56 & 2.73 & 1.25 & 1.63 & 4.33 & 7.58 & 3.46 & 4.52 \\
\hline 1977 & 2.15 & 3.72 & 1.68 & 2.21 & 5.96 & 10.32 & 4.66 & 6.15 \\
\hline 1978 & 2.42 & 4.22 & 1.95 & 2.52 & 6.71 & 11.73 & $5.4 I$ & 6.99 \\
\hline 1979 & 3.19 & 5.38 & 2.63 & 3.33 & 8.86 & 14.94 & 7.30 & 9.24 \\
\hline 1980 & 3.69 & 6.08 & 3.05 & 3.83 & 10.26 & 16.89 & 8.47 & 10.65 \\
\hline 1981 & 4.05 & 6.61 & 3.34 & 4.21 & 11.25 & 18.37 & 9.29 & 11.70 \\
\hline 1982 & 4.56 & 7.33 & 3.78 & 4.74 & 12.66 & 20.36 & 10.50 & 13.17 \\
\hline 1983 & 4.69 & 7.53 & 3.80 & 4.82 & 13.04 & 20.93 & 10.56 & 13.40 \\
\hline 1984 & 4.80 & 7.70 & 3.88 & 4.92 & 13.33 & 21.38 & 10.79 & 13.68 \\
\hline 1985 & 5.62 & 8.87 & 4.55 & 5.76 & 15.62 & 24.63 & 12.63 & 16.00 \\
\hline 1986 & 6.71 & 9.94 & 5.13 & 6.64 & 18.65 & 27.61 & 14.26 & 18.45 \\
\hline 1987 & $\begin{array}{r}7.89 \\
-\end{array}$ & 10.98 & 5.47 & 7.43 & 21.91 & 30.50 & 15.20 & 20.65 \\
\hline 1988 & 8.7I & II.52 & 5.73 & 7.96 & 24.20 & 31.99 & 15.90 & 22.12 \\
\hline 1989 & 9.03 & | & 5.78 & 8.17 & 25.08 & 32.53 & 16.05 & 22.69 \\
\hline 1990 & 9.22 & 11.72 & 5.73 & 8.23 & 25.62 & 32.56 & 15.91 & 22.87 \\
\hline 1991 & 9.81 & 11.59 & 5.78 & 8.40 & 27.24 & 32.18 & 16.06 & 23.33 \\
\hline 1992 & 10.27 & 11.49 & 6.00 & 8.62 & 28.52 & 31.92 & 16.67 & 23.95 \\
\hline 1993 & 10.78 & 11.15 & 6.01 & 8.68 & 29.93 & 30.97 & 16.70 & 24.12 \\
\hline 1994 & II.37 & 10.90 & 5.88 & 8.75 & 31.58 & 30.28 & 16.33 & 24.30 \\
\hline 1995 & 11.93 & 10.72 & 6.21 & 9.04 & 33.14 & 29.78 & 17.26 & 25.1! \\
\hline 1996 & 12.68 & 10.92 & 6.17 & 9.36 & 35.23 & 30.33 & 17.14 & 26.01 \\
\hline 1997 & I3.4| & 10.91 & 6.11 & 9.56 & 37.25 & 30.30 & 16.96 & 26.56 \\
\hline 1998 & 13.19 & 10.56 & 6.64 & 9.72 & 36.64 & 29.34 & 18.44 & 26.99 \\
\hline 1999 & 13.28 & 10.20 & 6.17 & 9.44 & 36.88 & 28.32 & 17.13 & 26.21 \\
\hline 2000 & 13.26 & 10.26 & 6.23 & 9.45 & 36.83 & 28.50 & |7.3! & 26.25 \\
\hline 2001 & 14.17 & 10.49 & 6.62 & 10.06 & 39.35 & 29.14 & 18.40 & 27.95 \\
\hline 2002 & 15.28 & 10.73 & 7.12 & 10.68 & 42.44 & 29.81 & 19.79 & 29.68 \\
\hline 2003 & 16.42 & II.69 & 7.91 & 11.60 & 45.60 & 32.48 & 21.96 & 32.23 \\
\hline 2004 & 17.96 & 12.27 & 8.00 & 12.28 & 49.90 & 34.08 & 22.21 & 34.10 \\
\hline 2005 & 19.19 & 13.25 & 9.05 & 13.32 & 53.29 & 36.79 & 25.13 & 37.00 \\
\hline 2006 & 20.56 & 13.85 & 9.30 & 14.06 & 57.11 & 38.46 & 25.83 & 39.06 \\
\hline 2007 & 22.10 & 14.14 & 9.79 & 14.79 & 61.39 & 39.29 & 27.20 & 41.08 \\
\hline 2008 & 23.28 & 14.94 & 10.87 & 15.99 & 64.67 & 4I.5I & 30.21 & 44.43 \\
\hline $2009 E$ & 24.44 & I5.64 & 11.73 & 17.08 & 67.89 & 43.44 & 32.58 & 47.45 \\
\hline
\end{tabular}

I Prices are derived by dividing total income received by total kilowatt-hours conveyed for each customer class.

2 National average prices are calculated as residential (including GST), commercial and industrial prices (excluding GST) weighted by consumption.

$\mathrm{E}=$ Estimated

Table 2.5 - New Zealand electricity prices (nominal) (Ministry of Economic Development, 2008) 


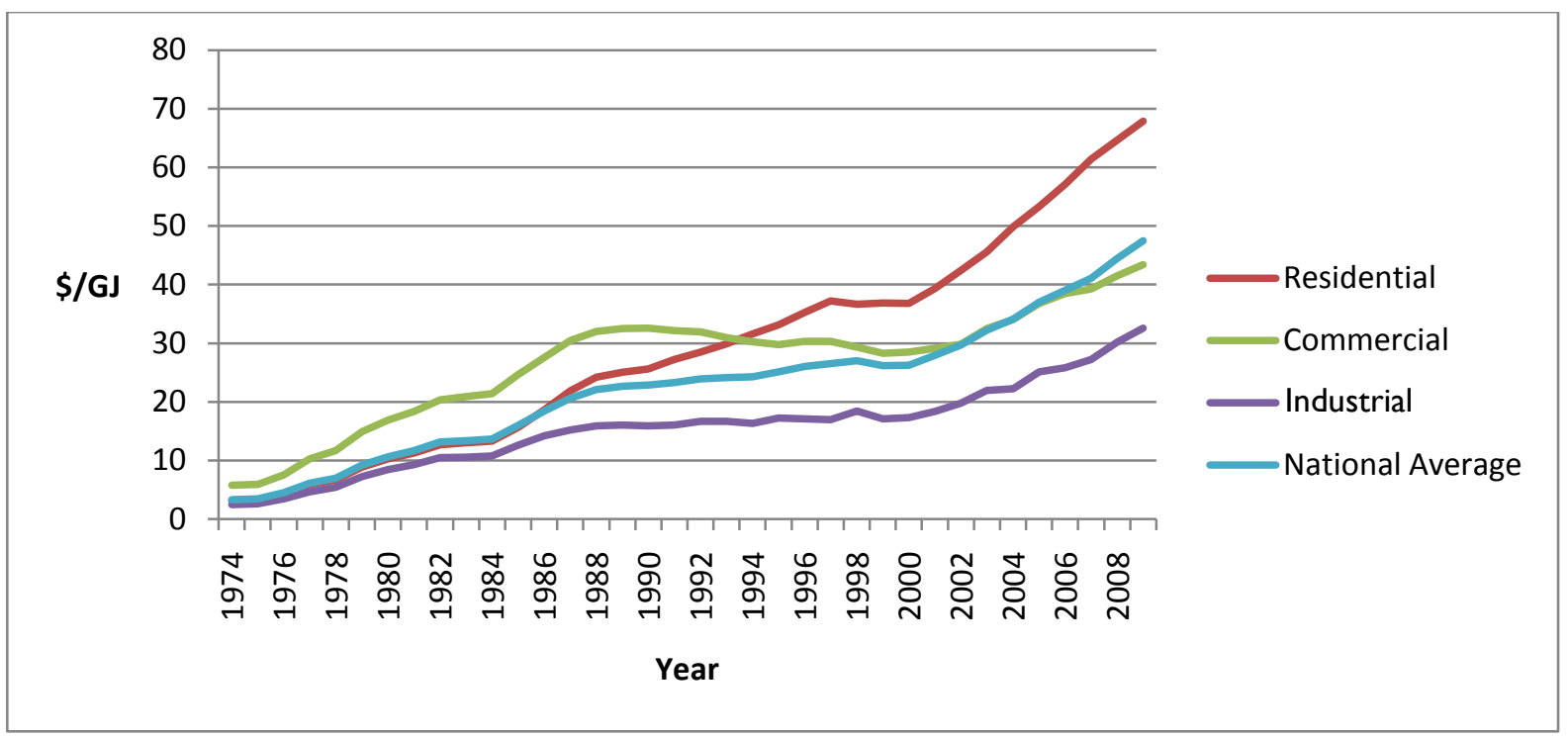

Figure 2.I5 - New Zealand electricity prices

The discussion above shows that as yet PVs are not common in New Zealand and the reasons for this are due to cost and lack of incentives. This is also true of PCM products which may struggle harder to reach the market because of the existence of an alternative, this being making thermal mass an integral part of the building structure. 


\section{Use of Phase Change Materials in Interiors}

\section{I Office Modelling Study}

The discussion above has suggested that the best way for PCMs to enter the current building market might be in the high end office interior fit-out, especially if in the form of products that can be made visually attractive. However, in order to consider appropriate design opportunities for integrating PCMs into the office environment it is important to look at current office configurations and the possibilities they make available. PCMs have a maximum functional thickness of approximately $10 \mathrm{~mm}$ due to their low conductivity. Greater depth also results in even lower financial viability due to the expense of the PCM, which lends them to a surface application. As the ideal office temperature is approximately 19-24 degrees Celsius (Rohles, 2007), some 13-18 degrees lower than body temperature at 37 degrees, to suit this, the functioning PCM temperature also needs to be approximately 19-24 degrees. It is also necessary to consider the proximity to the human body, for instance will the surface feel uncomfortable if the PCM is too close?

In an open plan environment the most readily available surfaces are workstation components, such as desk, chair and partition/pin up board. This leads to another design consideration, ownership. There is the question of whether PCMs and their potential energy savings should be part of the structure in order for the heating, ventilation and air conditioning systems to be designed as part of the lowest energy use building operation modes, or whether they can be part of the tenancy equipment, where if the owner moves on so does the energy saving PCM product.

In a product developed with energy conservation and eco-friendliness in mind, consideration must also be paid to the second of the ever important three Rs - Reuse. To make PCM products easily reusable in order to reduce future production - not necessarily the most profitable goal but the most socially responsible one - it is then sensible to design a package with assembly and disassembly in mind rather than focusing on the first use of the product. This brings the issue back to ownership, and questioning the relationship of possibly 'temporary' PCM products with the permanent HVAC systems.

\section{I.I Office Audit}

To design a base building size for modelling use of PCMs in an office interior and in the absence of any data from the BEES study, when this work was done, an audit of 22 office fit-outs over 10 Wellington city buildings was completed (buildings 3-10 in Table 3.I below ). The fit-outs were randomly selected within the need to have readily accessible plans. The two sources used for obtaining the necessary documents were plans from the Wellington city council that were recent enough to be held at the council and not at archives, or those accessible to the author via 
professional connections. All fit-outs were completed between 2000 and 2008. Plans were assessed to provide the area in $\mathrm{m}^{2}$ of the following;

Overall usable floor area (Net Lettable Area, NLA)

Open plan floor area

Cellular office area

Meeting spaces

Area of gypsum wall (counted each side of wall)

Glazed partition walls

High mass (core) walls

Gypsum ceilings

Grid ceiling systems

The floor to ceiling, and floor to floor heights and number of doors were also audited. The area of surfaces was then assessed as a percentage of the overall floor area. The results are summarised and shown in Table I below. In the event, buildings I and 2 have been excluded due to incomplete data. Each area is shown as area in square metres and as a percentage of either the total floor area or total wall surface area as applicable.

The results from Table I show that the area of Gib, and hence the area for installing a PCM board, varied from a maximum of $95 \%$ of wall area (Floor 0 Building 3) to a minimum of $40 \%$ (Floor 3 in the same building). 


\begin{tabular}{|c|c|c|c|c|c|c|c|c|c|c|c|c|c|c|}
\hline \multirow{2}{*}{ 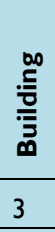 } & \multirow{2}{*}{ 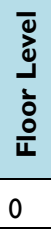 } & \multirow{2}{*}{ 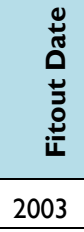 } & \multirow{2}{*}{ 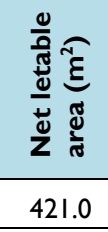 } & \multicolumn{2}{|c|}{ 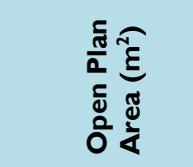 } & \multicolumn{2}{|c|}{ 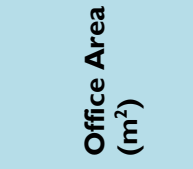 } & \multicolumn{2}{|c|}{ 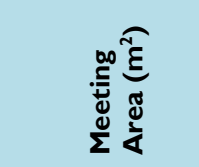 } & \multirow{2}{*}{ 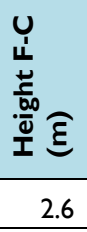 } & \multicolumn{2}{|c|}{ 苂 } & \multicolumn{2}{|c|}{ 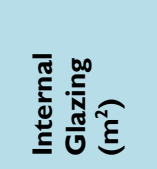 } \\
\hline & & & & 300.0 & $71 \%$ & 0.0 & $0 \%$ & 106.0 & $25 \%$ & & 410.7 & $95 \%$ & 22.1 & $5 \%$ \\
\hline 4 & 1 & 2001 & 1873.0 & 1276.8 & $68 \%$ & 68.5 & $4 \%$ & 78.5 & $4 \%$ & 2.6 & 834.1 & $51 \%$ & 104.7 & $6 \%$ \\
\hline 4 & 2 & 2001 & 1266.0 & 555.1 & $44 \%$ & 18.5 & $1 \%$ & 282.5 & $22 \%$ & 2.6 & 1017.3 & $76 \%$ & 157.7 & $12 \%$ \\
\hline 4 & 3 & 2001 & 1873.0 & 1140.0 & $61 \%$ & 40.5 & $2 \%$ & 109.2 & $6 \%$ & 2.6 & 575.0 & $40 \%$ & I55.I & $11 \%$ \\
\hline 4 & 4 & 2001 & 1873.0 & 830.5 & $44 \%$ & 259.1 & $14 \%$ & 153.8 & $8 \%$ & 2.6 & 1228.8 & $59 \%$ & 161.3 & $8 \%$ \\
\hline 5 & 12 & 2006 & 1252.4 & 1065.0 & $85 \%$ & 0.0 & $0 \%$ & 135.1 & $11 \%$ & 2.7 & 922.9 & $61 \%$ & 38.9 & $3 \%$ \\
\hline 5 & 13 & 2006 & 2577.0 & 278.3 & $11 \%$ & 616.4 & $24 \%$ & 181.5 & $7 \%$ & 2.7 & 1625.9 & $69 \%$ & 166.9 & $7 \%$ \\
\hline 5 & 14 & 2006 & 2577.0 & 1525.4 & $59 \%$ & 124.0 & $5 \%$ & 107.8 & $4 \%$ & 2.7 & 1075.7 & $64 \%$ & 59.9 & $4 \%$ \\
\hline 5 & 15 & 2006 & 2577.0 & 278.3 & $11 \%$ & 717.9 & $28 \%$ & 181.5 & $7 \%$ & 2.7 & 815.6 & $53 \%$ & 166.9 & $11 \%$ \\
\hline 5 & 16 & 2006 & 2577.0 & 278.3 & $11 \%$ & 717.9 & $28 \%$ & 181.5 & $7 \%$ & 2.7 & 815.6 & $53 \%$ & 166.9 & $11 \%$ \\
\hline 5 & 17 & 2006 & 2577.0 & 188.0 & $7 \%$ & 0.0 & $0 \%$ & 1408.9 & $55 \%$ & 2.7 & 1058.9 & $54 \%$ & 134.2 & $7 \%$ \\
\hline 6 & 1 & 2006 & 1365.0 & 456.7 & $33 \%$ & 0.0 & $0 \%$ & 287.5 & $21 \%$ & 2.5 & 617.3 & $76 \%$ & 60.7 & $7 \%$ \\
\hline 6 & 2 & 2006 & 1365.0 & 788.0 & $58 \%$ & 0.0 & $0 \%$ & 71.0 & $5 \%$ & 2.5 & 207.0 & $49 \%$ & 82.0 & $19 \%$ \\
\hline 6 & 3 & 2006 & 1365.0 & 228.2 & $17 \%$ & 28.8 & $2 \%$ & 66.6 & $5 \%$ & 2.5 & 269.0 & $73 \%$ & 97.5 & $27 \%$ \\
\hline 7 & 3 & 2007 & 727.2 & 472.2 & $65 \%$ & 33.0 & $5 \%$ & 86.2 & $12 \%$ & 2.6 & 81.1 & $68 \%$ & 38.2 & $32 \%$ \\
\hline 8 & 1 & 2008 & 1172.1 & 1172.1 & $100 \%$ & 1172.1 & $100 \%$ & 0.0 & $0 \%$ & 2.6 & 77.5 & $41 \%$ & 0.0 & $0 \%$ \\
\hline 9 & 2 & 2010 & 1012.1 & 1012.1 & $100 \%$ & 1012.1 & $100 \%$ & 0.0 & $0 \%$ & 2.6 & 77.5 & $41 \%$ & 0.0 & $0 \%$ \\
\hline 9 & 3 & 2010 & 1012.1 & 1012.1 & $100 \%$ & 1012.1 & $100 \%$ & 0.0 & $0 \%$ & 2.6 & 77.5 & $41 \%$ & 0.0 & $0 \%$ \\
\hline 9 & 4 & 2010 & 1012.1 & 1012.1 & $100 \%$ & 1012.1 & $100 \%$ & 0.0 & $0 \%$ & 2.6 & 77.5 & $41 \%$ & 0.0 & $0 \%$ \\
\hline 9 & 5 & 2010 & 736.0 & 736.0 & $100 \%$ & 736.0 & $100 \%$ & 0.0 & $0 \%$ & 2.6 & 77.5 & $41 \%$ & 0.0 & $0 \%$ \\
\hline 10 & 13 & 2007 & 676.8 & 119.0 & $18 \%$ & 101.9 & $15 \%$ & 135.5 & $20 \%$ & 2.6 & 540.8 & $77 \%$ & 98.5 & $14 \%$ \\
\hline \multicolumn{3}{|c|}{$\begin{array}{l}\text { Average floor } \\
\text { area }\end{array}$} & 1594.3 & & & & & & & & & & & \\
\hline
\end{tabular}

Table 3.I - Wellington office audit

\section{I.2 Modelling Assumptions}

As a result of the office audit two base buildings were created for the modelling study to investigate the use of phase change materials in commercial interiors. Both buildings (square and rectangular) had a floor area of $1600 \mathrm{~m}^{2}$ and core area of $200 \mathrm{~m}^{2}$ with the core positioned to the centre of the south face of the building. The base buildings were totally open plan. Building $S$ was a $40 \mathrm{~m} \times 40 \mathrm{~m}$ square and Building $R$ had a shallow rectangular configuration of $20 \mathrm{~m} \times 80 \mathrm{~m}$ with the long side facing north. Later, cellular offices were included around the building perimeter but positioned so that the open plan area has a direct access to a glazed façade, as shown in Figure 3.I and Figure 3.2. These cellular offices were included to give extra internal partitions for the positioning of PCM materials. The third variation gives an indication of the effect of using PCM materials in free standing partitions in a totally open plan office. 


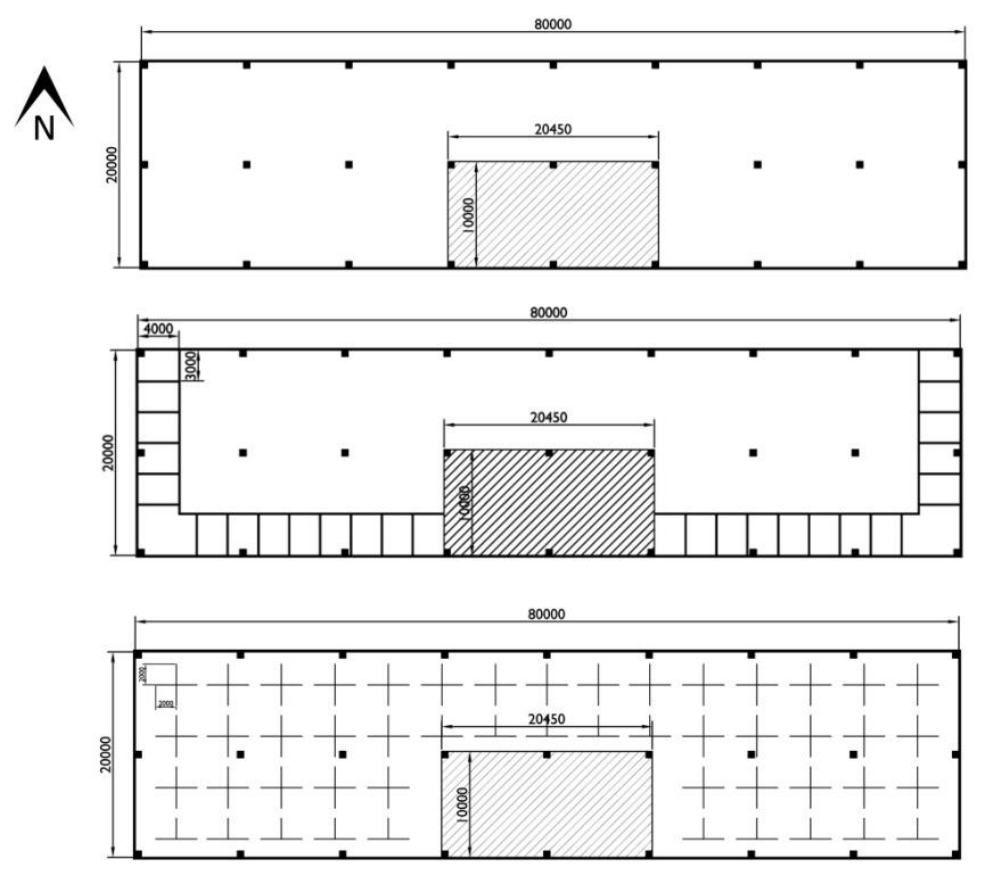

Figure 3.I - Rectangular floor plan variations showing base, walls and screening partitions,
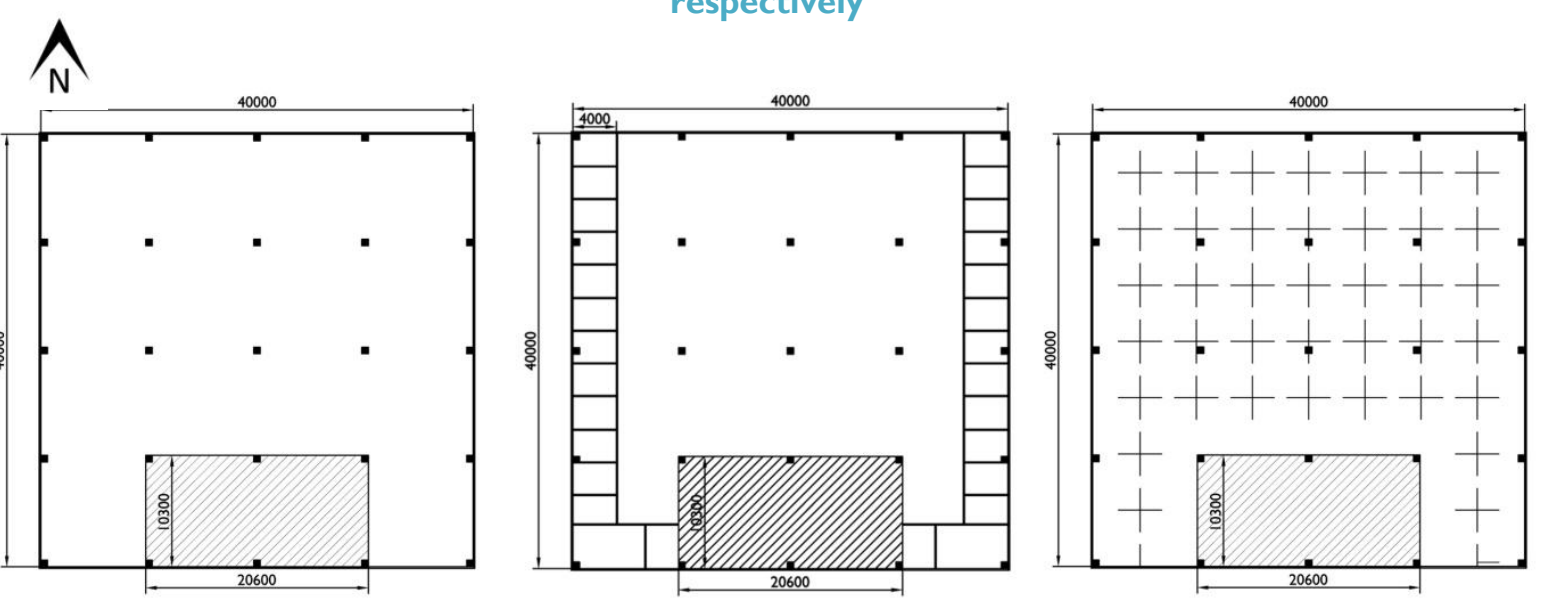

Figure 3.2 - Square floor plan variations showing, base, walls and screening partitions, respectively 


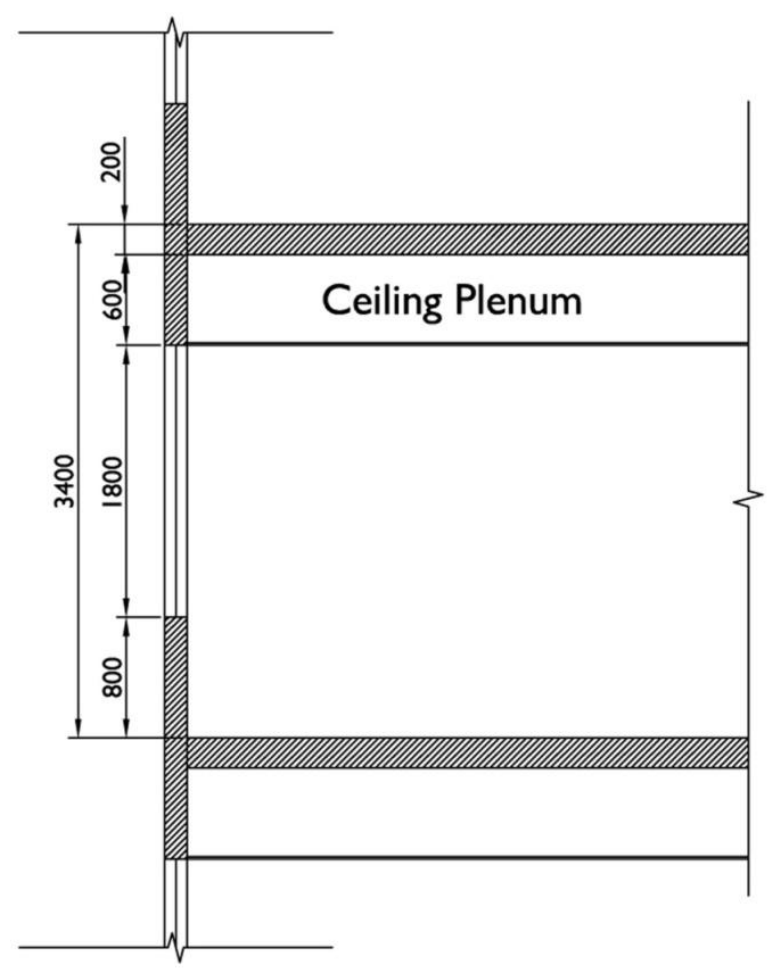

Figure 3.3 - Model building section

According to the early findings of the Building Energy End-use Study (BEES) investigation into office floor areas (only available after this study was completed), the following bands each represent buildings with floor areas that form $20 \%$ of all New Zealand office floor areas (Standards, NZS 4303:1990, 1990) (Isaacs, et al., 2009, p. 24).

$5 m^{2}-649 m^{2}$

$650 m^{2}-1,499 m^{2}$

$1,500 m^{2}-3,499 m^{2}$

$3,500 m^{2}-8,999 m^{2}$

$9,000 \mathrm{~m}^{2}+$

This would support a $1,600 \mathrm{~m}^{2}$ floor area as an appropriate model base since it falls into the middle of the range.

Modelling for the office study has been completed with EnergyPlus energy simulation software with SketchUp add-in for the building parameters. Building construction is consistent with current building code for multistorey office buildings; plastered concrete and double glazed exterior walls, carpeted concrete floors, and steel stud and gypsum board interior partitions. The base building is unshaded. 
Weather files for Auckland, Wellington and Christchurch have been imported from EnergyPlus data files, in which New Zealand data is sourced from the New Zealand National Institute of Water and Atmospheric Research Ltd (NIWA).

Data for internal conditions for occupation and ventilation have been taken from NZS 4303:1990, and for lighting and electronic equipment power use from NZS 4243: Part I:2007. Heating, ventilation and cooling systems have been set to maintain desired comfort levels (18-24 $\left.{ }^{\circ} \mathrm{C}\right)$ between the hours of $8 \mathrm{am}$ and 6pm Monday to Friday, allowing the building to be free running at other times. As well as looking for reduction in energy use, the study looked for any increase in comfort hours during the free running period (For full data see modelling report in Appendix I: Modelling Data).

\section{I.3 Construction and Materials}

Apart from the base building described above, other typical New Zealand construction and materials were modelled as depicted in Table 3.2 below. While the majority of commercial building stock is single glazed, this modelling uses double glazing as it is now the current minimum under the New Zealand building code. All material values were taken from CIBSE (A). The final two components listed were materials specifically tested as simulation variations as discussed in Section 3. 


\begin{tabular}{|c|c|c|}
\hline Component & Construction & Materials \\
\hline Glazing & Double Glazing & $\begin{array}{l}\text { - } \quad \text { Single } 3 \mathrm{~mm} \text { clear pane of glass } \\
\text { - } \quad 13 \mathrm{~mm} \text { air gap } \\
\text { - } \quad \text { Single } 3 \mathrm{~mm} \text { clear pane of glass }\end{array}$ \\
\hline Floor & Concrete Slab & $\begin{array}{l}\text { - } \text { Earth } \\
\text { - } 200 \mathrm{~mm} \text { Concrete Slab } \\
\text { - Carpet }\end{array}$ \\
\hline Roof (and ceiling) & $\begin{array}{l}\text { Long -run profiled } \\
\text { metal sheet on timber } \\
\text { frame }\end{array}$ & $\begin{array}{ll}\text { - } & 4 \mathrm{~mm} \text { Steel cladding } \\
\text { - } & \text { I00mm Timber Roof Frame with } 94 \mathrm{~mm} \\
& \text { Insulation (R I.8) } \\
\text { - } & \text { Gib Board Lining }\end{array}$ \\
\hline Exterior Wall & $\begin{array}{l}\text { Concrete Wall with } \\
\text { plastered } 40 \mathrm{~mm} \text { EPS }\end{array}$ & $\begin{array}{l}\text { - } \text { Cement Plaster } \\
\text { - } 40 \mathrm{~mm} \text { EPS } \\
\text { - } \quad 150 \mathrm{~mm} \text { Concrete Tilt Slab Wall } \\
\text { - Gib Board Lining }\end{array}$ \\
\hline Interior Wall & $\begin{array}{l}\text { Lined Timber Framed } \\
\text { Walls }\end{array}$ & $\begin{array}{ll}\text { - } & \text { Gib Board Lining } \\
\text { - } & \text { 100mm Timber Wall Frame } \\
\text { - } & \text { Gib Board Lining }\end{array}$ \\
\hline $\begin{array}{l}\text { Phase Change } \\
\text { Material }\end{array}$ & $\begin{array}{l}\text { PCM tested on Gib } \\
\text { Board where used in } \\
\text { above constructions }\end{array}$ & - Standard Gib Board with PCM component \\
\hline Double Gib Board & $\begin{array}{l}\text { Double Gib Board } \\
\text { replaced standard Gib } \\
\text { Board where used in } \\
\text { above constructions }\end{array}$ & - Double thickness Gib Board \\
\hline
\end{tabular}

Table 3.2 - Construction and materials for typical office

\section{I.4 Phase change material data}

Though the PCM content of the various products on the market is not generally published with the marketing material the limit of PCM saturation in a $10-15 \mathrm{~mm}$ plasterboard type product appears to be $30-35 \%$ by weight (Peippo, Kauranen, \& Lund, 1991a) (Behzadi, 2010). The content of Energain is higher at 60\% (Kuznik, Virgone, \& Johannes, 2010, p. 1006) but the board is only $5 \mathrm{~mm}$ thick. Modelling for this study has been completed with two different saturation levels of a $10 \mathrm{~mm}$ Gypsum plaster board; $5 \%$ - the default EnergyPlus setting, and 30\% as a known maximum saturation.

\section{I.5 Modelling Methodology}

Firstly, the two buildings $S$ and $R$ were modelled without PCMs. This produced baseline non-PCM models against which to assess all other variations. To assess the effect of the amount of PCM used, seven variations were set up. These included the non-PCM baselines $\left(S_{0}, R_{0}\right)$ plus 6 different combinations related to where the PCM product was put. These are shown in Table 3.3 - PCM below. 


\begin{tabular}{|r|l|l|l|l|l|}
\hline & Perimeter Walls & Internal Partitions & Ceilings & Floors & Description \\
\hline 0 & Base & Base & Base & Base & Baseline \\
\hline 1 & PCM & Base & Base & Base & PCM in perimeter walls \\
\hline 2 & Base & Base & PCM & Base & PCM in ceiling \\
\hline 3 & Base & PCM & Base & Base & PCM in internal partitions \\
\hline 4 & PCM & Base & PCM & Base & PCM in perimeter walls \& ceiling \\
\hline 5 & PCM & PCM & Base & Base & $\begin{array}{l}\text { PCM in perimeter walls \& internal } \\
\text { partitions }\end{array}$ \\
\hline 6 & PCM & PCM & PCM & Base & $\begin{array}{l}\text { PCM in perimeter walls \& internal } \\
\text { partitions \& ceiling }\end{array}$ \\
\hline
\end{tabular}

Table 3.3 - PCM variations

Construction variations were then also added to assess the effect on the PCM as follows;

\begin{tabular}{|l|l|}
\hline Glazing & Glazing added to Southern façade \\
\hline Insulation & Insulation increased \\
\hline Overhang & Im overhangs added to east, north \& west facades \\
\hline Partitions & As per floor plans, screening partitions were added as a surface area of 'internal mass'. \\
\hline Shading & $\begin{array}{l}\text { A 'building' was added across the 'road' to the north. The 'building' was the same width } \\
\text { as the office but was twice the height }\end{array}$ \\
\hline $\begin{array}{l}\text { Rooms } \\
\text { with } \\
\text { Internal } \\
\text { Mass }\end{array}$ & $\begin{array}{l}\text { The main office zone was divided into three smaller zones (East, Main and West office } \\
\text { zones). The East \& West offices were made up of a series of smaller offices. Internal } \\
\text { screening partitions added to model inter-office partitions }\end{array}$ \\
\hline $\begin{array}{l}\text { Rooms } \\
\text { without } \\
\text { Internal } \\
\text { Mass }\end{array}$ & $\begin{array}{l}\text { As per floor plans. West \& East offices modelled as one zone (each). No internal } \\
\text { screening partitions added to model inter-office partitions }\end{array}$ \\
\hline
\end{tabular}

Table 3.4 - Construction variations

Each set of seven PCM variations was then modelled for each set of eight construction variations in each of three locations, Auckland, Wellington and Christchurch, for each of the two base floor plates. This provided 504 sets of data for comparison.

It was then decided that another variation of double layer non-PCM gypsum lining should be added to compare the effect of the PCM against this added mass, and this was added to the Welling ton rectangular model only, as it was seen to be the best performing. This variation produced a further 7 sets of data.

\section{I.4 Results}

All the summarised results below are annual figures. The full data set can be found on the DVDRom submitted as part of this thesis. 
Baseline:

Comfort Hours -The baseline buildings without any PCMs $\left(S_{0} \& R_{0}\right)$ perform best in Wellington followed by Christchurch, then Auckland when looking at the percentage of comfort hours (temperature between $18-24^{\circ} \mathrm{C}$ ).

Heating Energy - Auckland had the lowest heating energy requirement, followed by Wellington and then Christchurch.

Cooling Energy - Christchurch had the lowest cooling energy requirement, followed by Wellington and then Auckland.

These figures are really no surprise.

\section{PCM Variation Analysis:}

Although data varied across the locations PCM variation 6 performed the best in both square and rectangular buildings, in terms of the least heating and cooling energy required. With a few exceptions (which were seen when the overhang or partitions were added to the rectangular building only) PCM variation 6 performed best when assessed for cooling only but varied more when assessed for heating. This result can be compared to the longer initial heat up period effect of higher mass as discussed in chapter 2.4, whereby intermittent heating does not work as well in an insulated high mass environment as continuous heating, because heat is need to raise the temperature of the mass as well as the air in the space.

\begin{tabular}{|l|lrrrr|}
\cline { 2 - 6 } \multicolumn{1}{c|}{} & \multicolumn{5}{c|}{ Energy Use (kWh) } \\
\hline \multirow{5}{*}{ Auckland } & $\mathrm{R}_{0}$ & Heating Energy & Cooling Energy & Total Energy & \% Decrease \\
& $\mathrm{R}_{6}$ & 164.1 & 12689.9 & 12854 & \\
\cline { 2 - 6 } & $\mathrm{S}_{0}$ & 154.8 & 12300.4 & 12455.2 & $3.1 \%$ \\
\hline \multirow{5}{*}{ Wellington } & $\mathrm{S}_{6}$ & 260.9 & 13078.5 & 13339.4 & \\
& $\mathrm{R}_{0}$ & 244.7 & 12834.4 & 13079.1 & $2.0 \%$ \\
& $\mathrm{R}_{6}$ & 1347.4 & 6043.2 & 7390.6 & \\
\cline { 2 - 6 } & $\mathrm{S}_{0}$ & 1356.4 & 5773.1 & 7129.5 & $3.5 \%$ \\
\hline \multirow{3}{*}{ Christchurch } & $\mathrm{S}_{6}$ & 1611.6 & 6227.4 & 7839 & \\
& $\mathrm{R}_{0}$ & 1603.4 & 6011.7 & 7615.1 & $2.9 \%$ \\
\cline { 2 - 6 } & $\mathrm{R}_{6}$ & 5510.2 & 5227.6 & 10737.8 & \\
\cline { 2 - 6 } & $\mathrm{S}_{0}$ & 5506.2 & 4931.1 & 10437.3 & $2.8 \%$ \\
\cline { 2 - 6 } & $\mathrm{S}_{6}$ & 6216.7 & 5128.5 & 11345.2 & \\
& & 6196.6 & 4866.3 & 11062.9 & $2.5 \%$ \\
\hline
\end{tabular}

Table 3.5 - Original construction type, baseline and PCM variation 6

The following Figures compare the savings from PCM in exterior walls and ceiling (variation 4) with PCM in exterior walls, ceiling and the internal partitions (variation 6) and with the double gib 
version. A further comparison in Figure 3.6 looks at the difference for the $5 \%$ and $30 \%$ PCM versions.

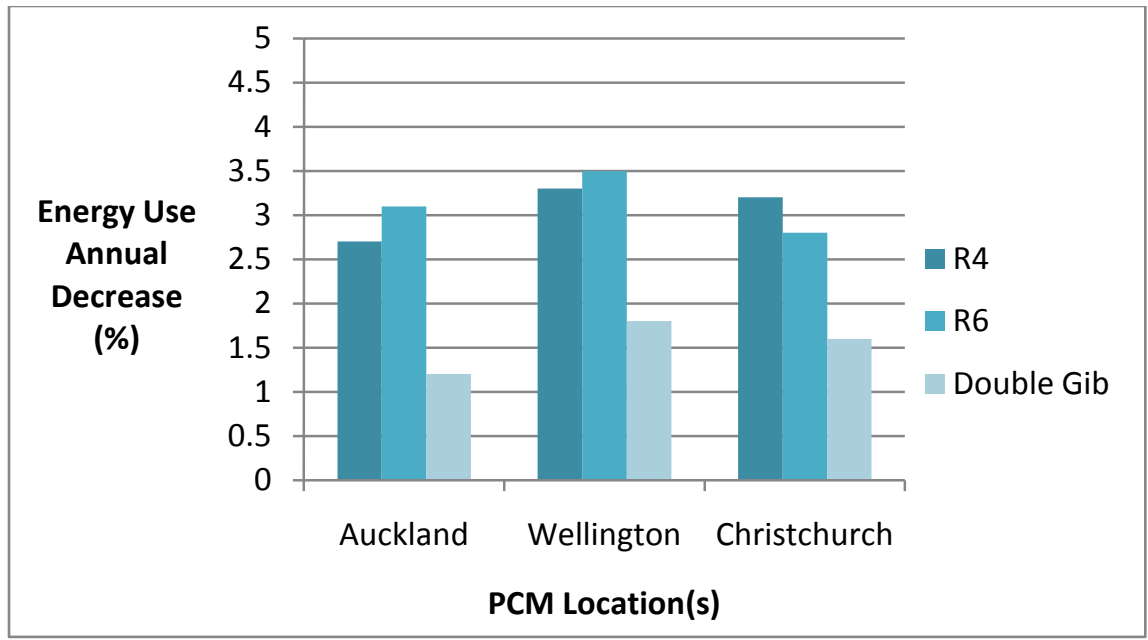

Figure 3.4 - Energy reduction in rectangular building simulation 5\% PCM content

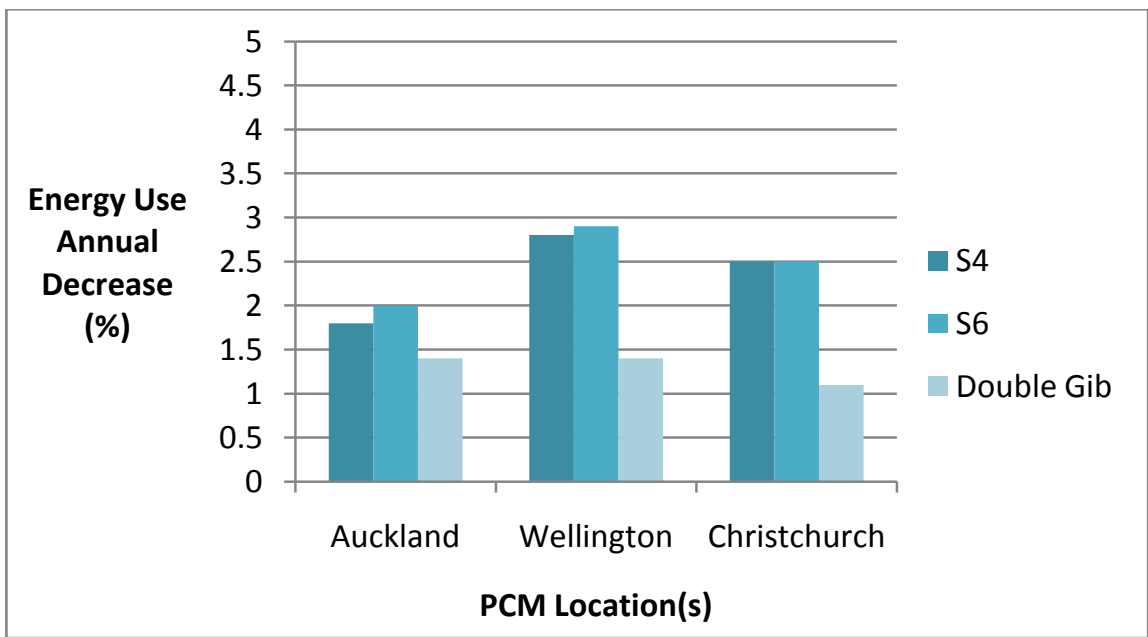

Figure 3.5 - Energy reduction in square building simulation 5\% PCM content

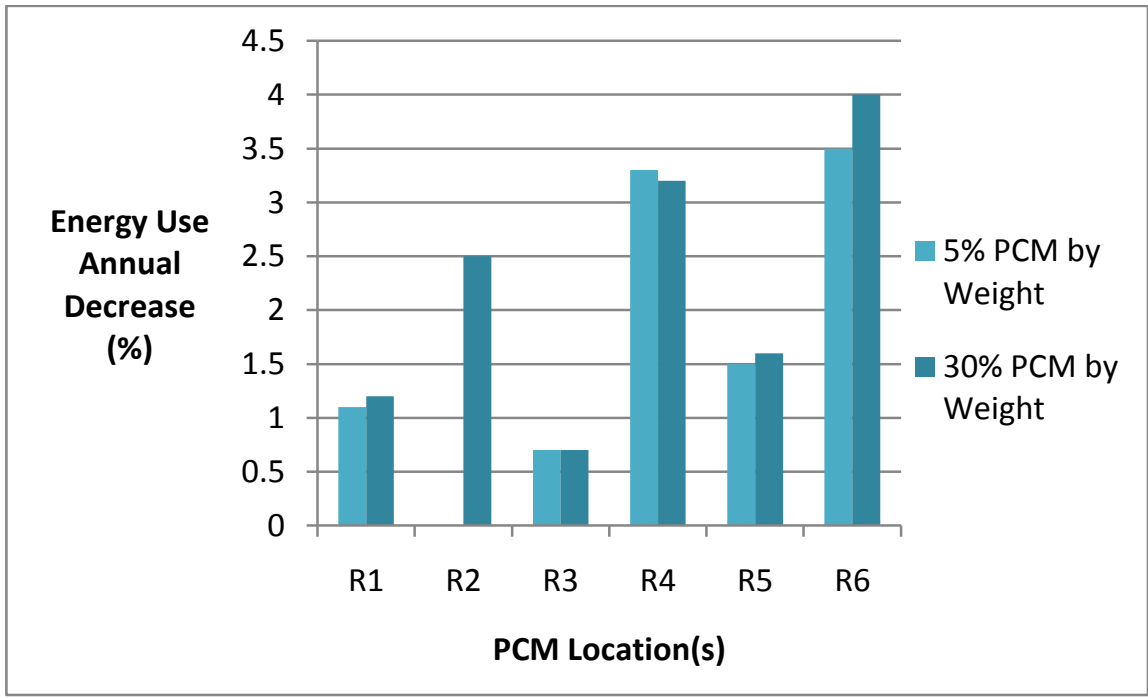

Figure 3.6 - Energy reduction comparison 5\% and 30\% PCM content 
The PCMs did not achieve as significant a result as might have been hoped. Overall, there was a reduction of $0-5 \%$ in the maximum heating and cooling energy required. Consistently PCM variations 3,4 , and 5 were very similar to 6 , only varying by $0.1 \%$ difference at times for both square and rectangular buildings. Although 8 different construction variations were modelled, the overall results did not vary a great deal from the original, with some exceptions. For example the added glazing in the square building in Christchurch produced a rise in annual energy use. The results are shown in Figure 3.7.

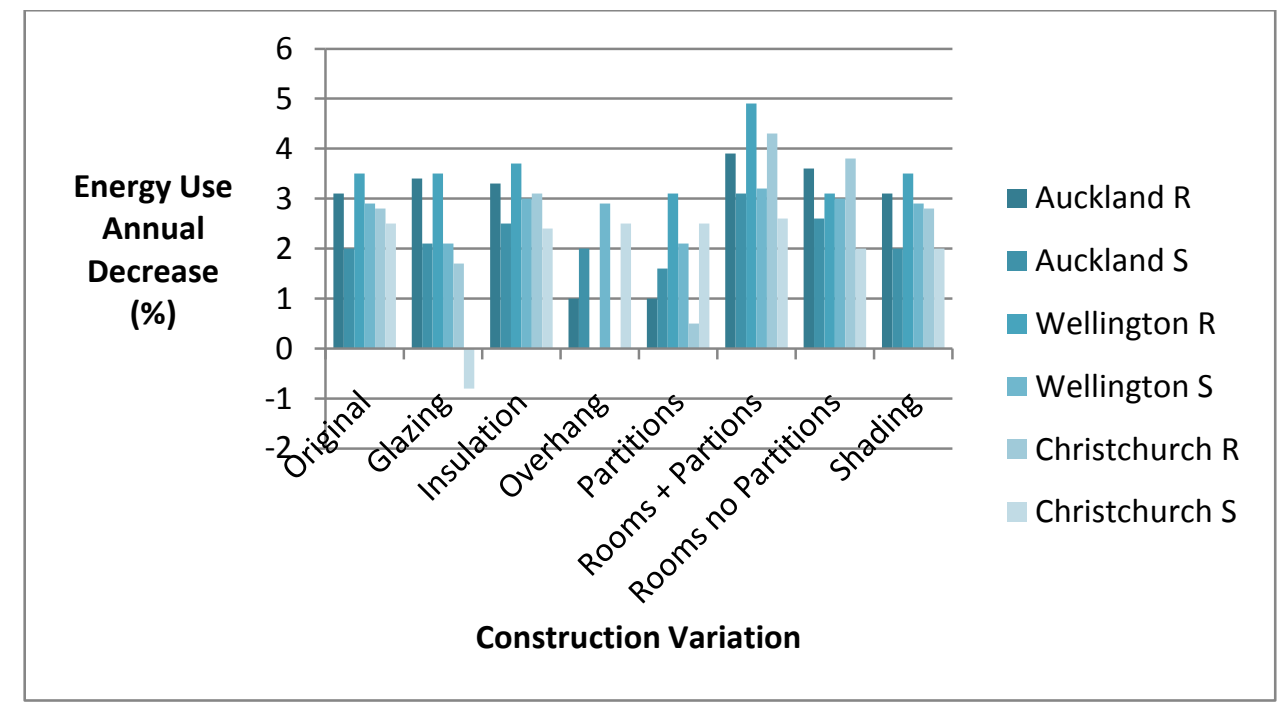

Figure 3.7 - Energy use reduction for construction variations

It was intended to show seasonal fluctuations but once the results were seen, because the PCMs achieved such a low energy saving the fluctuations seemed insignificant. However, it would be reasonable to assume that in a residential building where seasonal change causes greater difference to the internal environment and with smaller room sizes, particularly room depth, greater seasonal fluctuation might be observed, and these results will be explored in chapter 3.2.

Generally the simulations have shown that the PCMs do not make a lot of difference to either the comfort hours or the heating/cooling energy consumed in office buildings. The best that can be achieved is an overall $5 \%$ reduction in annual energy use and this is achieved by applying PCM materials to every available surface.

\subsection{Residential Modelling Study - University of Auckland}

The model used in the simulation produced by the University of Auckland Department of Materials and Chemicals Engineering aims to represent a typical, lightweight residential house in New Zealand, see appendix 2 . The house has two single bedrooms, one double bedroom, one bathroom, an openplan kitchen - living-room, a corridor and a single garage. The total area of the house is $121 \mathrm{~m}^{2}$. This model uses gypsum plaster board impregnated with PCM by immersion technique using the Paraffin 
PCM, RT2I, produced by Rubitherm (Rubitherm Technologies GmbH, 200I). The modelling schedules are shown below in Table 3.6 and Table 3.7.

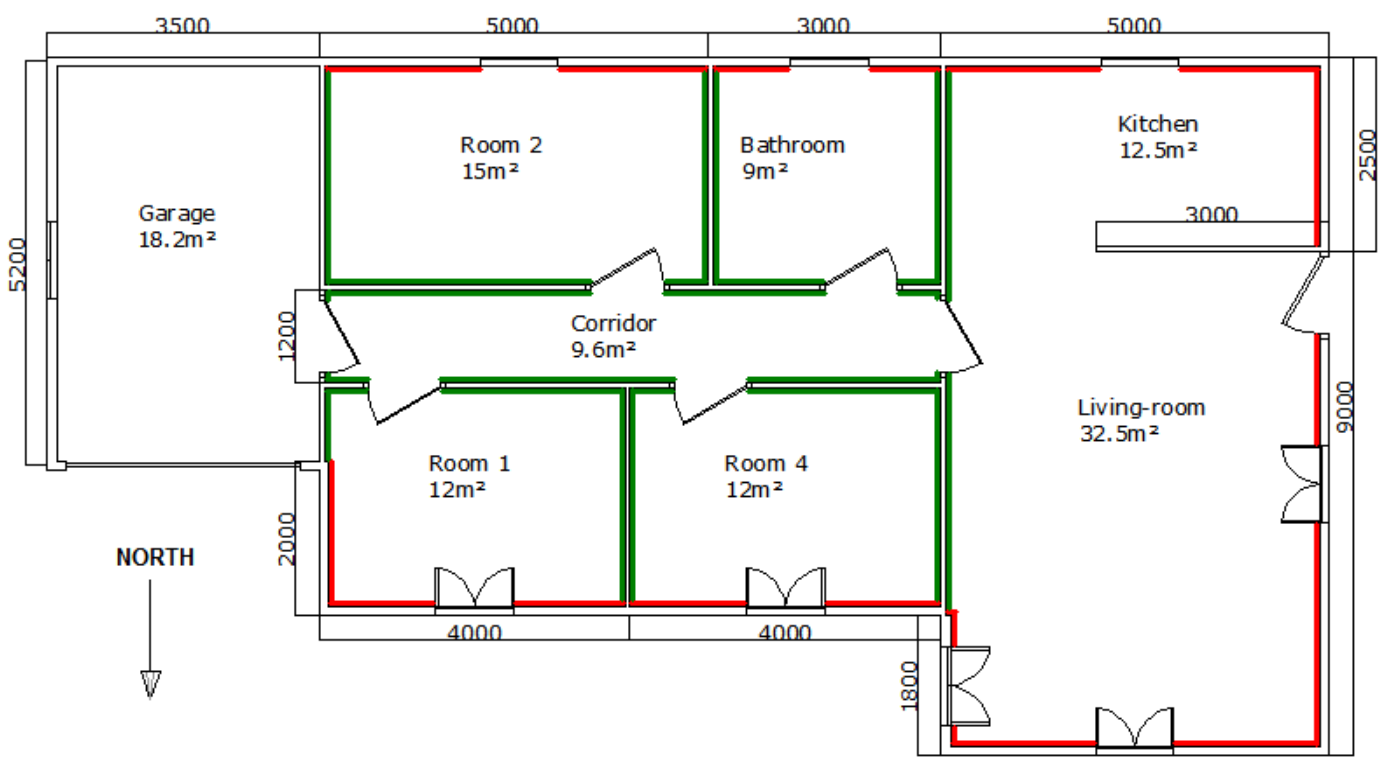

Figure 3.8 - Generic house plan

\begin{tabular}{|c|c|c|}
\hline Component & Construction & Materials by depth $(\mathrm{m})$ \\
\hline \multirow[t]{4}{*}{ External Walls } & \multirow[t]{4}{*}{ Timber frame } & Gypsum $(0.013 \mathrm{~m})$ \\
\hline & & Insulation $(0.075 \mathrm{~m})$ \\
\hline & & Timber $(0.025 \mathrm{~m})$ \\
\hline & & Siding $(0.01 \mathrm{~lm})$ \\
\hline \multirow[t]{3}{*}{ Internal Walls } & \multirow[t]{3}{*}{ Timber frame } & Gypsum $(0.013 \mathrm{~m})$ \\
\hline & & Insulation $(0.040 \mathrm{~m})$ \\
\hline & & Gypsum $(0.013 \mathrm{~m})$ \\
\hline \multirow{4}{*}{$\begin{array}{l}\text { Roof } \\
\text { (and ceiling) }\end{array}$} & \multirow[t]{4}{*}{ Light weight } & Gypsum $(0.013 \mathrm{~m})$ \\
\hline & & Insulation $(0.12 \mathrm{~m})$ \\
\hline & & Timber $(0.025 \mathrm{~m})$ \\
\hline & & Siding $(0.0 \mathrm{~lm})$ \\
\hline \multirow[t]{2}{*}{ Ground } & \multirow[t]{2}{*}{ Insulated concrete } & Concrete $(0.15 \mathrm{~m})$ \\
\hline & & Insulation $(0.015 \mathrm{~m})$ \\
\hline
\end{tabular}

Table 3.6 - Construction and materials for typical house (See Appendix 2: Auckland Residential Model) 


\begin{tabular}{|l|l|}
\hline Parameter & Assumption \\
\hline Weather data file & Auckland airport \\
\hline Air infiltrations for all zones & $0.6 \mathrm{ACH}$ \\
\hline Mechanical ventilation except bathroom & $0.5 \mathrm{ACH}$ \\
\hline Mechanical ventilation for bathroom when in use & $2 \mathrm{ACH}$ \\
\hline Mechanical ventilation for bathroom when not in use & $0.5 \mathrm{ACH}$ \\
\hline Heat transfer coefficient (inside) & $3.05 \mathrm{~W} / \mathrm{m}^{2} . \mathrm{K}$ \\
\hline Heat transfer coefficient (outside) & $17.8 \mathrm{~W} / \mathrm{m}^{2} . \mathrm{K}$ \\
\hline Solar absorption (inside) & $60 \%$ \\
\hline Solar absorption (outside) & $75 \%$ \\
\hline
\end{tabular}

Table 3.7 - Model parameters (See Appendix 2: Auckland Residential Model)

During summer (December to February), the cooling and heating temperatures are respectively set to $22^{\circ} \mathrm{C}$ and $15^{\circ} \mathrm{C}$.

During the rest of the year, they are respectively set to $25^{\circ} \mathrm{C}$ and $20^{\circ} \mathrm{C}$.

The full outline of this study can be seen in appendix 2. The results are shown below in graphs to make them comparable to the office modelling of this study, though as the Auckland data has been modelled in TRNSYS the inputs required and programme parameters vary from those used in the Energy Plus model for this study.

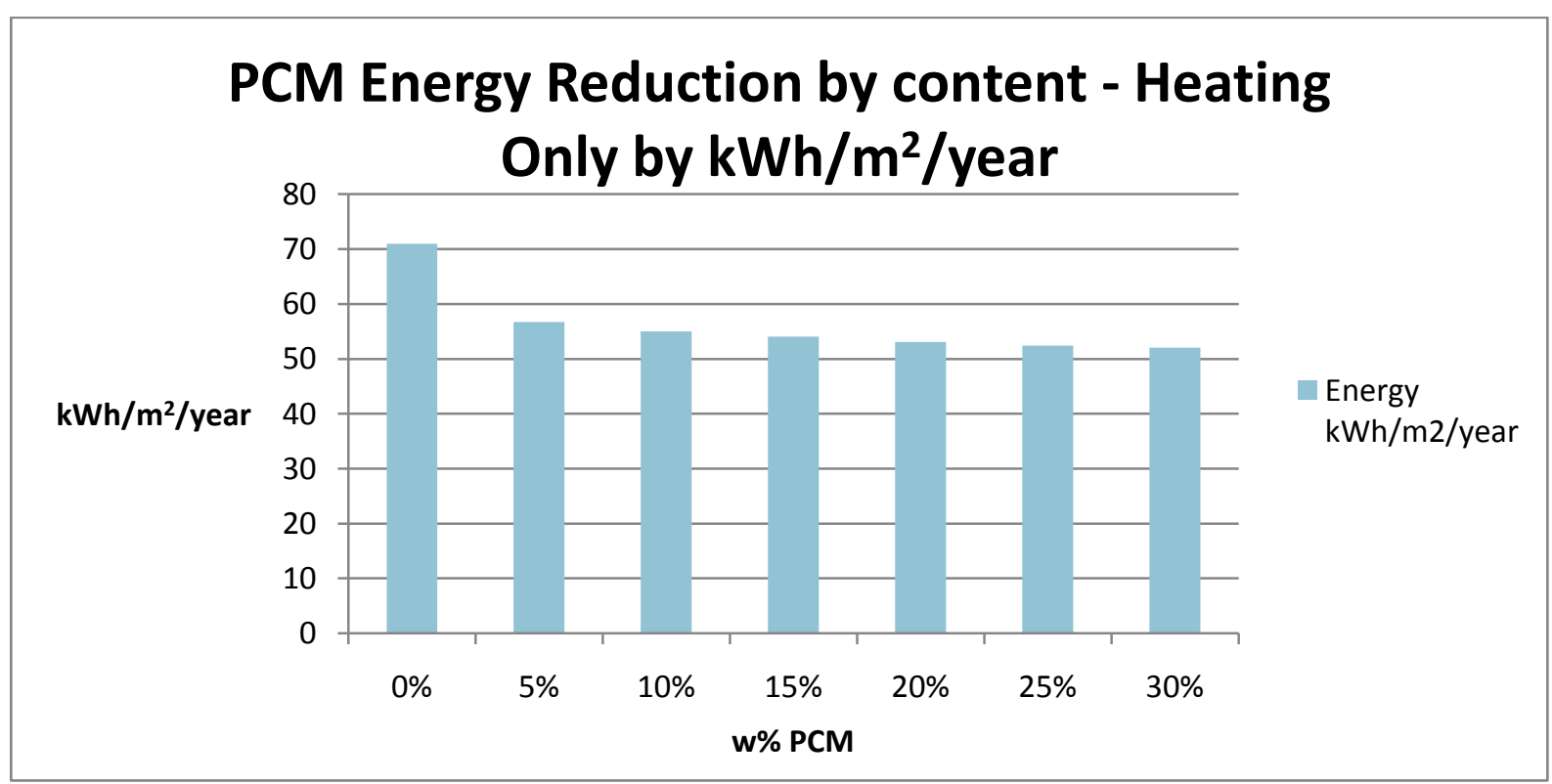

Figure 3.9 - PCM energy reduction by content - heating and cooling only by $\mathrm{kWh} / \mathrm{m}^{2} / y e a r$ 


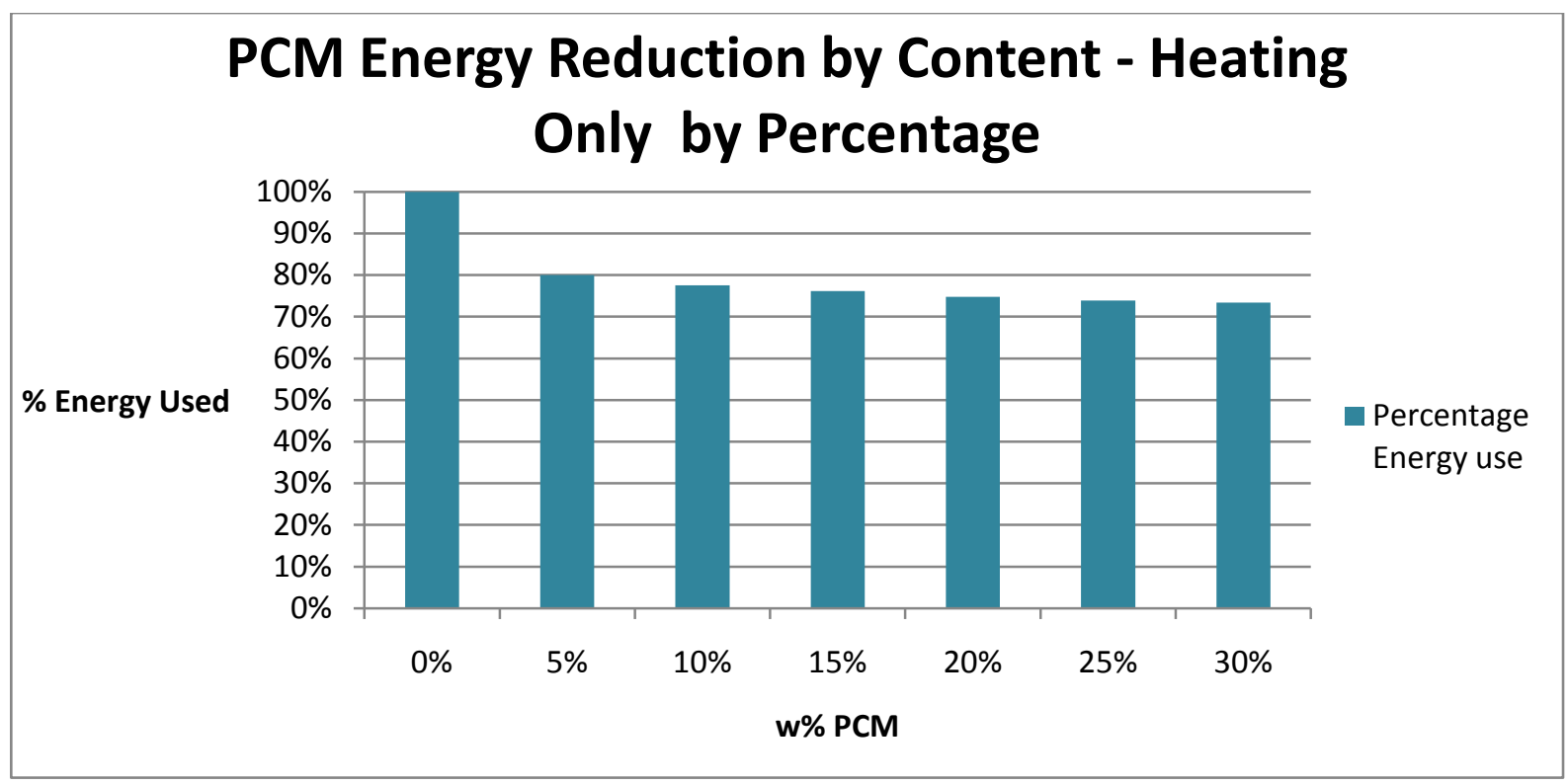

Figure 3.10 - PCM energy use reduction by content - heating only by percentage

The data from the Auckland University model includes both heating and cooling. As it is unusual to cool dwellings in New Zealand (Isaacs, et al., 2006, p. v), even in summer, the results discussed here are only those for heating. These results indicate that while increased energy saving is achieved with increased PCM content, the most significant saving is by the addition of the initial $5 \%$ PCM per weight of gypsum board, saving approximately $20 \%$ of energy used, while the added addition of a further $25 \%$ PCM to achieve the maximum saturation of $30 \%$ as discussed in chapter 3.1 .4 , only increases the energy reduction by a further $5 \%$. This suggests that the most effective product would be a cheap 5\% PCM board to improve the heating energy use in lightweight houses in New Zealand.

As the energy use figures in the Auckland University residential model are very high compared with those researched in this study, $8584 \mathrm{kWh} /$ year as opposed to less than $4000 \mathrm{kWh} / y e a r$ as discussed below, the energy use reductions have been taken as percentages from Figure 3.10 - PCM energy use reduction by content - heating only by percentage above and applied to more substantiated annual energy use figures as described below.

Using the BRANZ Annual Loss Factor (ALF) tool (BRANZ, N.d.) Version 3.2, and the known parameters of the house modelled and based on heating 24 hours daily, the predicted annual energy use for home heating was $3236 \mathrm{kWh} /$ year. The BRANZ Household Energy End-use Project (Isaacs, et al., 2006, p. iii) shows that the total annual energy use from all fuel sources for the bottom $20 \%$ of homes is $6,940 \mathrm{kWh} / y e a r$, and for the top $20 \%$ of homes is $14,450 \mathrm{kWh} / y$ ear. The HEEP study also shows that $34 \%$ of total household energy use is used for space heating. Taking the median HEEP energy use of 10,695 kWh/year and taking $34 \%$ of this, the average annual household space heating energy use is $3,636.3 \mathrm{kWh} /$ year. This figure supports the ALF estimate made on the modelled house, 
though it should be noted the model house is small and is also based in the Auckland climate, whereas the HEEP study figure for space heating is a New Zealand wide average. The more realistic ALF figure is used in the cost calculation below.

In order to calculate a cost that could be deemed viable for a PCM product it is logical to work backwards from the savings results. The maximum $20 \%$ heating energy saving achieved by the PCM based on the value of $3236 \mathrm{kWh} /$ year is $647 \mathrm{kWh} /$ year. When this is multiplied by the average residential electricity cost from table 2.4 of 24.44 c, it equates to savings of $\$ 158$ per annum. If this is extrapolated over the average seven year term for home ownership before moving on (Mithraratne, Vale, \& Vale, 2007, p. 5) the total cost saving is \$1 I06. The amount of Gib in the generic house modelled, as per Figure 3.8, is approximately $250 \mathrm{~m}^{2}$, excluding the garage. This means, therefore, the PCM Gib could cost $\$ 4.40$ more per $\mathrm{m}^{2}$, or $\$ 12.70$ more per $1.2 \times 2.4$ sheet to break even in terms of energy savings over the seven years. The price of a $1.2 \times 2.4$ sheet of standard I3mm Gib is approximately $\$ 30$, thus the proposed increase of $\$ 12.70$ is a $42 \%$ increase in cost.

While the Auckland study has targeted a typical New Zealand home, at $121 \mathrm{~m}^{2}$, including an attached single garage, this could be considered a small home by current standards. The average floor area of a new home increased by $25 \%$ between 1970 , at $146 \mathrm{~m}^{2}$, and 2000 , at $194 \mathrm{~m}^{2}$ (Mithraratne, Vale, \& Vale, 2007, p. I5I), and if it is accepted that $55 \%$ of the building stock current in 2006 , when the HEEP study was completed, was built after 1970 (Centre for Housing Research, 2004) it must then be assumed that over $55 \%$ of homes are greater than $146 \mathrm{~m}^{2}$, and thus are $20 \%$ bigger than the Auckland generic house as modelled above. If the average home is, in fact, significantly bigger than this generic house, yet the average home energy use is not, then the viable price increase per area of PCM wall board would be reduced.

A standard I $3 \mathrm{~mm}$ sheet of Gib weighs $25 \mathrm{~kg}$, or $8.7 \mathrm{~kg} / \mathrm{m}^{2}$ (Winstone Wallboards Ltd, N.d.). At $5 \%$ of the total weight the required weight of PCM would be $1.25 \mathrm{~kg}$, meaning the PCM addition must cost less than NZ\$10.16 per kg including profit. Looking back at the costs shown in chapter I.3.I this is currently not possible although it does set a target to be aimed for in the development of cheaper PCM products, such as those from tallow.

In order to make use of PCMs in buildings ways that add value to the product must be found, and even better be part of product development, as discussed in chapter 2.4.

\subsection{Retrofit conditions}

In the studies in chapters 3.1 and 3.2 above assumptions are made based on a new-build situation, while in retrofit situations there are additional considerations to be made including the option of 
alternative energy saving measures, i.e. installing insulation batts or injected expanding foam systems to improve the R-value of the external walls. The installation of either insulation batts and/or new linings (such as PCMs) means that additional expenses are incurred such as plastering and painting and reinstallation of skirtings, scotias and architraves. Injected expanding foam style insulation incurs fewer of these expenses though it does not entirely eliminate them as the holes in the external walls have to be painted over, which ideally means repainting the exterior walls of the house, or timing this with the installation of the foam. While batts and injected expanding foam may increase insulation, neither will add mass that can store the free energy of the sun. In an ideal world it might be worth relining with PCM board in addition to the installation of batts in the walls, but not until the cost of the PCM board drops as discussed above in chapter 3.2.

\subsection{Effects of Mass in Office Interiors}

A U.S. study (Marceau \& VanGeem, 2007) on the effect of additional mass in commercial buildings energy use across a range of climates (Chicago, Denver, Memphis, Miami, Phoenix and Salem), shows that while in mild climates such as Miami the variation is small, in other less mild, locations the addition of higher thermal mass to the structural frame can produce savings of $6 \%-9 \%$. These energy savings are higher than those produced in the PCM modelling discussed in this study, though as they are produced using different software (VisualDOE and Energy-10) they are not directly comparable. The modelling results of the U.S study (attached in appendix 4) also show fluctuations across the variations tested that show in some instances the energy use is increased by the addition of mass, as in the PCM modelling of this study (see Chapter 3.I.5). The U.S. study also finds that addition mass located in or near the building envelope is more effective at reducing energy use that mass located at the core of the building.

A New Zealand study (Bricknell Moss Ltd, 1988) found that while the effect of building weight (mass) on heating energy alone was negligible due to the amount of "Heatup" energy required, the effect on cooling loads was significant due to the effect of the mass delaying the effect of heat gains until after occupation hours. The effect on cooling was large enough to offset any increased heating and produce an annual energy saving. The Bricknell Moss study also found that although the heating energy saving was negligible, the effect of mass in evening out any temperature fluctuations resulted in a more comfortable environment that needed less sophisticated control systems to maintain desired temperatures. The study also found that if occupation hours were near 24 hours (such as in a call centre) the benefits were increased due to offsetting the Heatup energy.

Both these studies indicate that both mass and PCM products could reduce energy use in office interiors, but that this reduction is not dramatic. 
Both studies mentioned above, as well as that conducted as part of this research, relate to the type of office building most prevalent in today's market, that of the North American model (as discussed in chapter 2.7) with deep floor plates and nonoperable windows, running on mechanical heating, cooling and ventilation. The potential for energy savings through use of mass, or PCMs, might be significantly increased when combined with innovative, well engineered passive design methods, such as in the Melbourne Council building discussed in chapter I.7.

\subsection{Energy Cost, Employees and Environment}

Aside from measuring the effectiveness of the use of PCM products in buildings, consideration must also be given to the decision making process implemented when making value decisions (earlier discussions on this can be found in chapter 2.3). In commercial office situations expenditure is monitored and reviewed and cost saving decisions are weighed against monetary cost which can be accurately assessed through accounting systems. The cost of implementing energy saving technologies, including loss of productivity of staff during implementation and the predicted ongoing cost saving may be evaluated against other cost saving measures such as reducing staff numbers, and the staff payroll will be the highest component of virtually all commercial office type operations. Efficiencies that are achievable in terms of energy savings may therefore be deemed financially insignificant when compared with staff and other costs. Conversely, environmental improvements may be seen to improve productivity, reducing employee turnover, absenteeism, tardiness, required overtime, vandalism, grievances and mental and physical health (Centre for Advanced Engineering, 1996), thereby offsetting the cost of the improvements. They may also be seen as part of a company's marketing strategy, such as aiming for the best Green Star rating (see chapter 2.8). Residentially home owners are less inclined to keep such tight financial records and people costs (labour, loss of productivity through disruption in the home) are not often monetized, and therefore cost savings may be weighed solely against the cost of installation.

\subsection{Revolutionising or Redesigning}

The burgeoning field of product development seems to stride ahead bringing ever improved products to the market but when examined in detail the fundamental qualities of these new products, be they paper, cars or space rockets, show that very little tends to change over time since their invention. It is quite conceivable that the driver of the original model $\mathrm{T}$ ford, when faced with a Toyota Prius, although it would have seemed 'futuristic', would still be able to recognise it as an automobile and could probably drive it on the road with ten minutes tuition on using the controls. While the advancements in speed, comfort, economy and safety of the interior occupant (with speed being the major change) are obvious, there is the missed opportunity to radically redesign a human 
transportation system that might not only reduce toxic emissions but eradicate them all together and reduce the danger not only to the occupant but also to the surrounding pedestrians, not to mention reducing or removing the huge use of resources involved in roading systems. The ability of the human population to accept change is acknowledged (see chapter 2.3) but with this comes the inability to admit that maybe the first design attempt was not the only, or even best, one. The automobile is an obvious example as it is associated with higher levels of technology, but the same is also true for the environments in which people house themselves. While pragmatic responses to building shelter with the materials immediately to hand is very valid and to be encouraged, for example using local resources to construct environmentally appropriate buildings even in extreme climates such as with Badgir (see chapter 2.3), the demand for increasing climate control at the push of a button, without modifying conditions by using personal control, such as putting on a jersey to feel warmer in the home or at work, has driven the development and consumption of 'improved' technologies without exploring radically new concepts which might eradicate the need for improving faulty ones. There is a fundamental problem with the fact that society currently pumps huge amounts of resources, both as direct energy use and as material goods, into creating acceptable comfort levels for occupants when human beings have managed to survive, largely comfortably, for thousands of years without this voracious consumption of resources. For all human creativity, obsession with technology has dominated invention and driven development into the highly energy reliant corner it occupies today. Unfortunately, the existing PCM products are not examples of designers, engineers and scientists working together to trying to answer the question "how can people live in houses and work in offices comfortably for the minimum use of resources?" but instead are another one of the stream of product improvements in modern society.

"It has long been recognized that most of the potential for increased energy efficiency is realized at the design stage." (Centre for Advanced Engineering, 1996). Over a decade ago in 1996 the CAE recognized the need for targets set by NZS 4220:1982 for new buildings to also be in place to halve the energy targets for existing buildings. However, this did not happen and many buildings built in the interim period, between 1982 and 2010 still consume large amounts of energy and are now considered to be part of the building stock that the sector is seeking to improve. Because these improvements are in existing buildings, familiar products can replace those already there, which is why PCM versions of Gib board have come on to the market. However, maybe there is a need for these products to be developed in conjunction with new uses of PCM materials that help to answer the question outlined above, "how can people live in houses and work in offices comfortably for the minimum use of resources?" 


\section{Conclusion}

\section{I Conclusions of this study}

The history of PCMs has not been a happy one. This study has found that there are not many Phase Change Material products on the market and those that are have been developed with very little input from designers or architects. With the exception of Glass $X$, these products are replacements for existing building materials with embedded PCMs that give no clue to their function. At the same time the PCM products are more expensive versions of familiar products, which means their uptake has been very slow, and some products have already disappeared from the market. The one place where PCM products do seem to be finding a market is as an energy storage element in conventional HVAC systems.

The modelling completed during the course of this study, indicates that when a PCM with the equivalent thermal properties to RT2I, produced by Rubytherm is used as an additive to $10-15 \mathrm{~mm}$ gypsum wall board lining the most significant energy saving is achieved by $5 \%$ by weight, or approximately 435 grams per square metre. Energy savings from using this type of PCM board in a commercial office interior will be between $0-4 \%$ of the total annual energy use costs. However, this would mean putting PCM board on every available surface within the modern office interior.

Despite previous international research, these studies have shown that in New Zealand PCM application has more benefit in residential application than in commercial.

The market position the current developments of PCMs occupy is unlikely to grow significantly unless one or more of the following occur;

- A significantly cheaper, and sustainable, PCM is found

- Domestic electricity prices rise so dramatically that the potential $20 \%$ space heating saving becomes far more significant

- A level of design value is added to the development of PCM products in order to attract a wider market

One major observation from this research is that there is a gap between designers and architects and scientists and engineers when it comes to the development of new products. In the making of low energy and sustainable buildings it has been recognised that a multi-disciplinary approach is vital for a successful outcome (see chapter 2.7), and it would seem logical that same would be true of developing new products towards the goal of sustainability. 
In order for architects to persuade clients to use new materials it is necessary to have accurate and validated information about their performance in buildings.

\subsection{Further Research}

Further research is needed to collect real data from real buildings to convince architects of the merits of PCMs.

In addition to collection of actual data, in order to develop products that express the function of the PCM aesthetically, clear or translucent materials that might be used to enclose the PCM on a macro scale need to be tested for compatibility with the PCM material, as do dyes that might be used to colour the latter.

Due to the low conductivity of PCMs and therefore their low functional depth their application is limited to a sheet type application and mounting details for these may take precedents from glazed partitioning and similar systems. Depending on the material used to encapsulate the PCM there may be potential for three dimensional moulding of products containing PCM materials.

Consideration needs to be given to expansion and contraction of the PCM during melting and solidifying. This has been achieved in Energain by the use of an internal matrix, or honey comb, a form which may be possible in translucent materials, or non-translucent materials sandwiched within translucent materials. The scale of the honey comb and intensity of dyes used in the PCM might be varied to give more visual interest.

All these design issues should be explored and developed simultaneously with the chemical and technical capabilities in order for the results to push the product development in interesting, and potentially unexpected directions.

Once the parameters and costs of compatible materials that can achieve visual impact have been established further consideration may be given to additional uses for these materials. In an open plan environment where few permanent surfaces are available for the installation of PCMs the most readily available surfaces are workstation components, such as desk, chair and screening partitions. This leads to another design consideration, ownership. There is the question of whether PCMs and their potential energy savings should be part of the structure in order for the heating, ventilation and air conditioning systems to be designed as part of the best potential building operation modes, or whether they can be part of the tenancy equipment, where if the owner moves on so does the energy saving PCM product. In order to establish the viability of PCM furniture products as an energy saving measure further testing, including real testing, will be needed to be conducted in buildings with a variety of HVAC systems. As shown in chapter 3.1 the maximum energy savings 
achieved with all available surfaces, including screening partitions, finished with PCM materials is less than $5 \%$, From this it could be assumed that using areas of PCM furniture alone is unlikely to produce a more significant thermal result, although their effect may be useful and marketable as an aid in behaviour modification to reduce energy use indirectly as discussed in chapter 2.4 .

In a product developed with energy conservation and eco-friendliness in mind, consideration must also be paid to the second of the ever important three Rs - Reuse. To make PCM products easily reusable in order to reduce future production - not necessarily the most profitable goal but the most socially responsible one - it is then sensible to design a package with assembly and disassembly in mind rather than focusing on the first use of the product. This brings the issue back to ownership and questioning the relationship of possibly "temporary" PCM products with the permanent HVAC systems.

All of the above needed to come together to make products that are attractive to architects. Once an attractive product is the result the architect will work hard to persuade the client to use it. Simulated results will always be treated with some suspicion. 


\section{Bibliography}

Advanced Environmental Concepts Pty Ltd. (2008). Melbourne City Council PCM-Based Cooling. Sydney.

Allen and Clarke. (2007). National Value Case for Sustainable Housing Innovations. Auckland: Beacon Pathway Limited.

'Anna'. (2008, October 6). Renewable Energy Tax incentives. Retrieved May 5, 2010, from Find Portable Solar Power: findportablesolarpower.com

Appenzeller, T. (2004, June). Think gas is expensive now? Just wait. You've heard it before, but this time it's for real: were at the beginning of the end of cheap oil. National Geographic Magazine , Pp. 80110.

Arup. (2010). Sustainability Consulting. Retrieved August 3, 2010, from Arup: www.arup.com/Services/Sustainability_Consulting.aspx

Aspect Furniture Limited. (2010). Retrieved August 9, 2010, from Aspect Furniture Limited: www.aspectfurniture.co.nz

ASPO International. (n.d.). Retrieved May 20, 2010, from ASPO International: www.peakoil.net/ ASPO. (2002). Newsletter No 23. The Association for the Study of Peak Oil.

Australian Gas and Power. (2010). Australian Gas and Power. Retrieved May 4, 2010, from Australian Gas and Power: www.australianpowerandgas.com.au/ourbrproducts/renewableenergybuybackplans

Australian Government Bureau of Meteorology. (2010). Climate Change. Retrieved July 22, 20I0, from Australian Government Bureau of Meteorology: www.bom.gov.au/climate/change/

Bahadori, M. N. (1994). Vaibility of Wind Towers in Achieving Summer Comfort in the Hot Arid Regions of the Middle East. Renewable Energy, 5(2) , pp. 879-892.

Banham, R. (1969). The Architecture of the Well-Tempered Environment. London: The Architectural Press.

Bannister, P., Guan, L., \& Page, I. (1996). Development of acceptable solutions for energy efficiency of office buildings. IPENZ Transactions, 24(I) , PP. 55-63.

Bannister, P., Guan, L., Isaacs, N., \& Page, I. (1998). Testing commercial building energy standards. IPENZ Transactions, 24(I) , Pp. 22-3I. 
Barbour, A. (2009, December 2). The Green Room - Innovation in Green Star Projects. Wellington: New Zealand Green Building Council.

BASF. (2007). From 3-liter house to the zero-heating cost house. Science Around Us .

BASF. (2006). Micronal $®$ PCM SmartBoard $®$ Intelligent Temperature Management in an Extremely Lightweight Approach.

BASF. (2004). Phase Change Materials - Latent Heat Storage for Interior Climate Control.

Bauer, A. (2009, May 12). Personal communication with Alex Bauer, customer representative at Sto New Zealand.

Beacon Pathway Limited. (2009). Improving Our Existing Homes - Retrofitting New Zealands Housing Stock. Wellington: Beacon Pathway Limited.

Behzadi, S. (2010, July 6). Personal Communication, Postdoctoral Fellow, Department of Chemical and Materials Engineering, The university of Auckland. Auckland.

Bernhardt, J. (2008). A Deeper Shade Of Green. Auckland: Balasoglou Books.

Bhatti, H. N., Hanif, M. A., Qasim, M., \& Ata-ur-Rehman. (2008). Biodoesel production from waste tallow. Fuel, 87 , pp. 296I-2966.

Bloch, M. (2008, June). Renewable energy grants, rebates and incentives. Retrieved May 5, 20I0, from Green Living Tips: www.greenlivingtips.com/articles/I52///Renewable-energy-rebates.html

Bluejay, M. (2010). Saving Electricity. Retrieved July 25, 20I0, from Michael Bluejay: michaelbluejay.com/electricity/computers.html BP. (2008). BP Statistical Review of World Energy Use. BP. BP. (20I0). BP Statistical Review of World Energy Use. BP.

BRANZ. (N.d.). ALF Home. Retrieved August 3, 20I0, from ALF: alf.branz.co.nz

BRANZ. (2010). Curent Reseach Commissions. Retrieved May 19, 2010, from BRANZ: www.branz.co.nz/current_research\#BEES

BREEAM. (2009). BREEAM: the Environmental Assessment Method . Retrieved August 3, 20I0, from BREEAM: www.breeam.org 
Bricknell Moss Ltd. (1988). Identification of Effective Energy Conservation Measures for the New Zealand Commercial Building Sector. Wellington: Ministry of Energy.

Buildings Department. (2009, April 24). Comprehensive Environmental Performance Assessment Scheme for Buildings. Retrieved August 3, 2010, from Buildings Department, The Government of the Hong Kong Special Administrative Region: www.bd.gov.hk/english/documents/index_CEPAS.html

Burghout, P. (20I0). Making Sustainability Sustainable. SBIO. Wellington.

Butti, K., \& Perlin, J. (1980). A Golden Thread: 2500 Years of Solar Architecture. Palo Alto: Cheshire Books.

Callau, M., \& Lloyd, B. (2010). Upgrading Housing in NZ for Thermal Efficiency. SBIO New Zealand Conference Proceedings, PP. I-18. Wellington: SBI0.

Centre for Advanced Engineering. (1996). Energy Efficiency: A Guide to Current \& Emerging Technologies, Volume I Buildings \& Transportation. Christchurch: Print City.

Centre for Housing Research. (2004). Changes in the Structure of the New Zealand Housing Market: Excutive Summary. DTZ New Zealand.

Chisti, Y. (2007). Biodiesel from Microalgae. Biotechnology Advances, 25 , 294-306.

Chisti, Y. (2007). Biodiesel from Microalgae. Biotechnology Advances , pp. 294-306.

Chisti, Y. (2008). Biodiesel from Microalgae Beats Bioethanol. Trends in Biotechnology, 26(3) , Pp. 126$|3|$.

Chisti, Y. (2008). Biodiesel from Microalgae Beats Bioethanol. Trends in Biotechnology, Pp. I26-I3I.

Christian. (2007). Latent Heat Storage - "Phase Change" Materials. md , pp. 88-89.

Colclough, S., Griffiths, P., \& schwander, S. (2009). Thermal Energy Storage and the Passive House Standard: How PCM incorporated into wallboard can aid thermal comfort. PLEA. Quebec City.

Cole, R. (2005). Building Environmental Assessment Methods: Redefining Intentions. Vancouver: School of Architecture, University of British Columbia.

Cory, S. (2008). Development of Compliance Documents. Wellington.

Cosella-Dorken. (2010). Delta-Cool. Retrieved July 7, 20I0, from Cosella-Dorken: www.doerken.de/bvf-ca-en/products/pcm/index.php 
Cosella-Dorken. (2009). Delta-cool 24 Product brochure. Cosella-Dorken.

Cosgrove, C. (2006, October 4). Energy Efficient Buildings a Top Priority. Retrieved July 22, 20I0, from Beehive.govt.nz: www.beehive.govt.nz

Crompton, T. (2008). Weathercocks and Signposts - The environment movement at a crossroads. Surrey: WWF.

CSIRO. (2007). Climate Change in Australia. CSIRO.

Cupples, J., Guyatt V, V., \& Pearce, J. (2007). Put on a jacket you wuss: cultural identities, home heating, and air pollution in Christchurch, New Zealand. Environments and Planning A, 39(I2), PP. 2883-2898.

DEFRA. (2008). A Framework for Proenvirnmental Behaviours. London: DEFRA.

Department of the Prime Minister and Cabinet. (2008, March). Final Report of the House Prices Unit: House Price Increases and Housing in New Zealand. Retrieved July 22, 2010, from Department of the Prime Minister and Cabinet: www.dpmc.govt.nz/dpmc/publications/hpr-report/hpr-4.html

Diesendorf, M. (2007). Greenhouse Solutions with Sustainable Energy. Sydney: University of New South Wales.

Donn, M., \& Thomas, G. (200I). Designing Comfortable Homes. Wellington: Cement and Concrete Association of New Zealand.

Du Pont. (2010). Energain. Retrieved March 07, 2010, from Energain: energain.co.uk/Energain/en_GB/index.html

Duffy, F. (2006). Justifying place in a virtual world. London: DEGW.

Duffy, F. (1988). The European Challenge. Architects' Journal, I87(33) , pp. 30-43.

Duffy, F. (1997). The New Office. London: Conran Octopus Limited.

Duffy, F. (1997). The New Office. London: Conrad Octopus.

Duffy, F. (2008). Working Beyond Walls: The government workplace as an agent of change. London: DEGW.

Duffy, F. (2004). Working Without Walls: An insight into the tranforming goverment workplace. London: DEGW. 
Dul, J., \& Weerdmeester, B. A. (1993). Ergonomics for Beginners: A Quick reference Guide. London: Taylor and Francis.

DuPont. (N.d). DuPont Energain - A thermal mass solution that's ready to make it's mark. Luxembourg: DuPont.

DuPont. (2006). DuPont Energain - Installation Guidlines. Luxembourg.

Econation. (2010, June I5). Passivhaus. Retrieved August 3, 2010, from Econation:

www.econation.co.nz/passivhaus.html

eCubed Building Workshop Ltd. (2008). Integrated Whole Building Design Guidelines. Wellington: Ministry for the Environment.

EECA. (2010). Funding for Insulation and Clean Heating. Retrieved March 9, 2009, from Energywise: www.energywise.govt.nz/funding-available/insulation-and-clean-heating

Energy Key. (2007). The Energy Performance Certificate (EPC) explained. Retrieved August 3, 20 I0, from Energy Key: www.energykey.co.uk/epc.html

Energy Saving Trust. (2003). The Hockerton Housing Project: a case study. London: Energy Saving Trust. Farid, M. M., Khudhair, A. M., Razack, S. A., \& Al-Hallaj, S. (2004). A review on phase change energy storage: materials and applications. Energy Conversion and Management, 45 , Pp. I597-I6I5.

Farid, M. (2009). Personal Communication.

Farid, M., \& Khudhair, A. M. (2008). Use of phase change materials for thermal comfort and electrical energy peak load shifting: experimental investigations. Auckland: University of Auckland.

Farid, M., \& Kong, W. J. (200I). Underfloor heating with latent heat storage. Proceedings of the Institution of Mechanical Engineers, 215 , Pp. I-9.

Farid, M., \& Mecaial, N. (2007). Use of Phase Change Materials for Thermal Comfort and Electrical Energy Peak Load Shifting. Auckland: The University of Auckland.

Farid, M., Khudhair, A. M., Chen, J. J., \& Bansal, P. K. (2008). Optimization of Thermal Energy Storage In Buildings Using PCM. Auckland.

Farid, M., Khudhair, A. M., Chen, J. J., \& Hamadi, N. K. (2008). Distributed Thermal Storage in Full-Scale Office Buildings Using Phase Change Materials. Auckland: University of Auckland. 
Farid, M., M.Khudhair, A., Razack, S. A., \& Al-Hallaj, S. (2003). A review on phase change energy storage: materials and applications. Energy and Conservation Management , Pp. I597-16I5.

Farid, M., Qureshi, W. A., \& Nair, N.-K. C. (2008). Demand Side Management Through Efficient Thermal Energy Storage Using Phase Change Material. Australasian Universities Power Engineering Conference 2008. Sydney, Australia.

Farid, M., Smith, M., Sabbah, R., \& Al Hallaj, S. (2007). Miniaturized refrigeration systems with advanced PCM micro encapsulation technology. 5th International Conference on Nanochannels, Microchannels and Minichannels. Puebla, Mexico.

Farid, M., Smith, M., Sabbah, R., \& Al-Hallaj, S. (2007). Miniaturized Refrigeration System with Advanced PCM Micro Encapsulation Technology. Proceedings of ASME ICNMM2007 (PP. I-8). Puebla: 5th International Conference on Nanochannels, Microchannels amd Minichannels.

findportablesolarpower.com. (2008, October 6). Renewable Energy Tax incentives. Retrieved May 5, 2010, from Find Portable Solar Power: findportablesolarpower.com

Formway Furniture Limited. (N.d.). Grid 2 Brochure. Wellington, New Zealand: Formway Furniture Limited.

Fortmeyer, R. (2009, May). Melbourne's Great Experiment: Technological ambition and daring-do provide a wealth of lessons for aspiring green designers. GreenSource Magazine .

Forty, A. (1986). Objects of Desire: Design and Society 1750-1980. London: Thames \& Hudson Ltd.

Fowler, N. (2010). Backyard Power Generation Backed. The National Business Review .

Fraunhofer. (200I). Exploiting latent heat in building materials. Fraunhofer Magazine , p. 58.

Fraunhofer. (2003). Wax-based heat storage for buildings. Research News, 7 .

Freeman, R. B. (1978). Job Satisfaction as an Economic Variable. The American Economic Review, 68(2) , pp. |35-|4I.

Fullbrook, D. (2007). Sustainable Government Buildings: Beyond Design A Best Practice Approach to Building Commissioning, Completion and Ongoing Operation. Wellington: Ministry for the Environment.

Gowri, K. (2004). Green Building Rating Systems: An Overview. ASHRAE Journal , Pp. 56-59.

Green Globes. (N.d.). About Green Globes. Retrieved August 3, 2010 , from Green Globes: www.greenglobes.com/about 
Green Star New Zealand. (2009, May I). Green Star Certified Projects, Education. Retrieved July 2I, 2010, from New Zealand Green Building Council:

nzgbc.org.nz/main/greenstar/elaboration/certifiedprojects/education/nzi3

Greifenhagen, W. (2004). The 3-Liter-house - An Innovation in the Modernization of Old Properties.

Ludwigshafen, Germany: BASF.

Hauer, A., Mehling, H., Schossig, P., Yamaha, M., Cabeza, L., Martin, V., et al. (200I). International Energy Agency Implementing Agreement on Energy Conservation through Energy Storage. Hull, Canada: Annex 17.

Hedge, A. (1982). The open-plan office: a systematic investigation of employee reactions to their work environment. Environment and Behavior, I4(5), PP. 5I9-542.

Heinberg, R. (N.d.). Oil and Transportation. Retrieved May 20, 2010, from Oil Depletion Protocol: www.oildepletionprotocol.org/

Herring, H., \& Roy, R. (2007). Technological Innovation, energy efficient design and the rebound effect. Technovation, 27 , pp. 194-203.

Hounsham, S. (2006). Painting the Town Green: How to persuade people to be environmentally friendly. London: Green-Engage Communications.

Howden-Chapman, P. (2006). Housing, Heating and Health Study: 2005/2006 Report One Aims and Methods. Wellington: He Kainga Oranga.

Howden-Chapman, P., Matheson, A., Crane, J., Viggers, H., Cunningham, M., Blakely, T., et al. (2007). Effect of insulating existing houses on health inequality: cluster randomised study in the community. British Medical Journal , pp. 334-460.

iiSBE. (2009). About iiSBE. Retrieved August 3, 2010, from International Initiative for a Sustainable built Environment: www.iisbe.org/

Inside Limited. (2007). Mighty River Power. Wellington.

Institution of Mechanical Engineers. (2010). Institution of Mechanical Engineers Events. Retrieved July 21, 2010, from Institution of Mechanical Engineers: nearyou.imeche.org.uk/events/event.htm?elD $=3645$

Isaacs, N. (20I0, January). Building for the Future. Build, II5 , p. 4. 
Isaacs, N. (2006). Energy use in New Zealand Households: Executive Summary. Wellington: BRANZ.

Isaacs, N., Camilleri, M., French, L., Pollard, A., Saville-Smith, K., Fraser, R., et al. (2006). Energy Use in New Zealand Households; Report on the Year 10 Analysis for the Household Energy End-use Project (HEEP). Wellington: BRANZ.

Isaacs, N., Saville-Smith, K., Bishop, R., Camilleri, M., Jowett, J., Hills, A., et al. (2009). Study Report SR 224: Building Energy End-Use Study (BEES) Years I \& 2. Wellington: BRANZ.

IT Power (Australia) Pty Ltd. (2009). Assessment of the Future Costs and Performance of Solar Photovoltaic Technologies in New Zealand. Wellington: New Zealand Ministry of Economic Development.

Jackson, T. (2005). Motivating Sustainable Consumption - a review of evidence on consumer behaviour and behavioural change. Surrey: Sustainable Development Research Network.

Jacques, R., Camilleri, M., \& Isaacs, N. (200I). New Zealand's Initiatives in 'Greening' Commercial Buildings. APEC 'Green Buildings - Investing in Our Future', (pp. I-9). Taipei.

Japan Sustainable Building Consortium (JSBC). (2006). An overview of CASBEE. Retrieved August 3, 2010, from CASBEE: www.ibec.or.jp/CASBEE/english/overviewE.htm

Jevons, W. S. (I866). The Coal Question. London: MacMillian and Co.

Khudhair, A. M., Farid, M. M., Chen, J. J., \& Bansal, P. K. (2007). Thermal Energy Storage in Buildings Using PCM: Computer Simulation. Proceedings of ISES World Congress 2007 (Vol. I - Vol. V) (Pp. 257262). Springer Berlin Heidelberg.

Khudhair, A. M., Farid, M. M., Chen, J. J., \& Hamadi, N. K. (2008). Distributed Thermal Storage in FullScale Office Buildings Using Phase Change Materials. Auckland: The University of Auckland.

Khudhair, A. M., Farid, M. M., Ozkan, N., \& Chen, J. J. (ND). Microencapsulated Phase Change Materials in Building Materials. Auckland: The University of Auckland.

Knauf. (2009). SmartBoard®. Retrieved March 07, 20I0, from Knauf:

www.knauf.de/pdf/bilder/detbl_wmv/k764e_2008-10.pdf

Kubiszewski, I. (2006, August 7). Telkes, Maria. Retrieved August 3, 2010, from The Encyclopedia of Earth: www.eoearth.org/article/Telkes,_Maria 
Kudhair, A., Farid, M. M., Chen, J. J., \& Bansal, P. K. (2006). Development and use of impregnated phase change materials in concrete for thermal cofort. Proceedings from IIR/IRHACE Conference. Auckland.

Kuznik, F., Virgone, J., \& Johannes, K. (2010). Development and validation of a new TRNSYS type for the simulation of external building walls containing PCM. Energy and Buildings, 42 , Pp. 1004-1009.

Kuznik, F., Virgone, J., \& Noel, J. (2008). Optimization of a phase change material wallboard for building use. Applied Thermal Engineering, 28 , pp. 129I-1298.

Lawrence Berkeley National Laboratory. (2009). Environment, Health \& Safety Division. Retrieved May 3I, 20I0, from Berkeley Lab: www.lbl.gov/ehs/ergo/index.shtml

Lee, T. (2008, December II). Home Energy Efficiency pays off at sale time. Manuka, ACT, Australia: Energy Partners.

Lloyd, C. R. (2006). Fuel Poverty in New Zealand. Social Policy Journal of New Zealand: Issue 27 , pp. I42-I55.

Mackintosh, L. (200I). Overview of New Zealand Climate. Retrieved May 19, 2010, from National Institute of Water and Atmospheric Research (NIWA): www.niwa.co.nz/education-andtraining/schools/resources/climate/overview

Marceau, M., \& VanGeem, M. (2007). Modeling Energy Performance of Concrete Buildings for LEED-NC Version 2.2: Energy and Atmosphere Credit I. Skokie, Illinios: Portland Cement Association.

Máté, K. (2009). Attitudes versus Actions: are interior designers genuinely embracing sustainable design through material selection?". Proceedings from the 5th International Conference of the Association of Architecture, (PP. I- I2). Wellington.

McDonough, W., \& Braungart, M. (2002). Cradle to Cradle : remaking the way we make things. New York: North Point Press.

McLennan, J. F. (2004). The Philosophy of Sustainable Design: the future of architecture. Kansas: Ecotone.

Melbourne City Council. (2008). Cooling System. Retrieved July 13, 20I0, from City of Melbourne: www.melbourne.vic.gov.au/Environment/CH2/aboutch2/Pages/CoolingSystem.aspx

Microtec laboritories. (2010). Micro PCM. Retrieved March 7, 2009, from Microtec: www.microteklabs.com/micropcm.html 
Mills, A., Farid, M., Selman, J. R., \& Al-Hallaj, S. (2006). Thermal conductivity enhancement of phase change materials using a graphite matrix. Applied Thermal Engineering, 26 , pp. I652-166I.

Ministry for the Environment. (2005). A Guide to Sustainable Office Fit-outs. Wellington: Ministry for the Environment.

Ministry for the Environment. (2008). Sustainable Development. Retrieved July 22, 2010, from Ministry for the Environment: www.mfe.govt.nz/publications/sus-dev/

Ministry of Economic Development. (2008). Electricity Consumer Prices (Nominal). Retrieved July 8, 2010, from Ministry of Economic Development: www.med.govt.nz

Ministry of Economic Development. (2008). Electricity Consumer Prices. Retrieved July 28, 2010, from Ministry of Economic Development: www.med.govt.nz

MIT. (N.d.). Solar Decathlon. Retrieved August 9, 20I0, from MIT:

web.mit.edu/solardecathlon/solar6.html

Mithraratne, N., Vale, B., \& Vale, R. (2007). Sustainable Living: The Role of Whole Life Costs and Values. Boston: Butterworth Heinmann.

New Zealand Green Building Council. (N.d.). Certified Projects. Retrieved May 30, 2010, from Green Star New Zealand: www.nzgbc.org.nz/main/greenstar/elaboration/certifiedprojects

New Zealand Green Building Council. (n.d.). About Green Star. Retrieved May 2010, 30, from Green Star New Zealand: www.nzgbc.org.nz

New Zealand Standard Model Building Bylaw. (1977). Chapter 4 Residential Buildings - Amendment 5. In NZS 1900:1964 (p. 29). New Zealand Standard Model Building Bylaw.

NZi3. (2009). NZi3 - National ICT Innovation Institute. Retrieved July 2I, 20 I0, from NZi3 - National ICT Innovation Institute: www.nzi3.com

Oommen, M., Knowles, M., \& Zhao, I. (2008). Should Health Service Managers Embrace Open Plan Work Environments? A Review. Asia Pacific Journal of Health Management, 3(2) , pp. 37-43.

Parr, T. (N.d.). Retrieved July 2, 2010, from www.tonyparr.nl/

Patel, H. \& Vale, B. (2009). Phase Change Materials in Buildings. Wellington. 
PCM Products Ltd. (2009). PCM Applications; Building Temperature Control. Retrieved July I3, 2010, from Phase Change Materials: Thermal Management Solutions:

www.pcmproducts.net/Building_Temperature_Control.htm

Pedersen, C. O. (2007). Advanced Zone Simulation in EnergyPlus: Incorporation of Variable Properties and Phase Change Material (PCM) Capability. Proceedings: Building Simulation 2007, PP. |34|-|345.

Peippo, K., Kauranen, P., \& Lund, P. D. (1991a). A Multicomponent PCM Wall Optimised for Passive Solar Heating. Energy and Buildings, 17 , pp. 259-270.

Peippo, K., Kauranen, P., \& Lund, P. D. (199/b). An Organic PCM Storage System with Adjustable Melting Temperature. Solar Energy, 46(5) , pp. 275-278.

Peippo, K., Lund, P. D., \& Vartiainen, E. (1999). Multivariate optimization of Design trade-offs for solar low energy buildings. Energy and Buildings, 29 , pp. 189-205.

Peyerbeer. (2005). Retrieved March 7, 2010, from Glass X:

www.glassX.ch/fileadmin/pdf/GLASSX_AG_products_0808I5_k_e.pdf

Peyerbeer. (2005). GlassXcrystal: The glass that stores, heats and cools. Retrieved August 9, 20I0, from GlassX: www.glassX.ch/fileadmin/pdf/GLASSX_AG_products_0808I5_k_e.pdf

Radich, A. (2004, June 9). Biodiesel Performance, Costs, and Use. Retrieved July 20, 20I0, from United States Energy Information Administration: www.eia.doe.gov/oiaf/analysispaper/biodiesel/

Research New Zealand. (2008). Household Sustainability Survey 2008. Wellington: Ministry for the Environment.

Richards, P. (2009, January 9). Solar Power and Your Electricity Company - Electricity Buy-Back Programmes. Retrieved May 4, 2010, from Ezine: www.ezinearticles.com

Roaf, S. (2009). Resource Quality Cascades in Traditional Low Energy Technologies: The Qanats and Badgirs of Yazd. 3rd Annual CIB Conference on Smart and Sustainable Built Environments. Delft.

Robinson, J. (2004). Squaring the Circle? Some Thoughts on the Idea of Sustainable Development. Ecological Economics , pp. 369-386.

Rohles, F. (2007). Temperature \& Temperament. ASHRAE , pP. I4-22. 
Ryu, S. (2010). How Victoria University's School of Architecture and Design Could Achieve Carbon Neutality in Energy Use Without Carbon Offsets. SBIO Conference Proceedings. Wellington: SBIO.

Saint, A. (1983). The image of the architect. New Haven: Yale University Press.

Schmidt, M. (2009). Retrieved March 7, 2010, from BASF:

www.basf.com/group/corporate/en/function/conversions:/publish/content/innovations/eventspresentations/energy-management/images/BASF_P-42I e-MSchmidt.pdf

Schubert, D. W. (N.d). 25 Sustainable Revitalization of the Brunk Quartier. BASF.

Shirkey, R. (2005). Incentives for Renewable Energy: The writing is on the wall... but our policy-makers choose to be illiterate. British Columbia: University of Victoria.

Skates, H. (2006). The design and development of an integrated solar collector and thermal energy storage window system for lightweight construction : a thesis submitted to the Victoria University of Wellington in fulfilment of the requirements for the degree of Doctor of Philosphy.

Solarplaza. (2010, June 17). UK solar PV market could benefit from German feed-in tariff cuts. Retrieved July 28, 2010, from Solarplaza: www.solarplaza.com

Standards, N. Z. (2007). NZS 4243:Part I:2007.

Standards, N. Z. (1990). NZS 4303:1990.

Standards, N. Z. (1990). NZS 4303:1990.

Stivers, R. (1976). The Sustainable Society: Ethics and Economic Growth. Philadelphia: Westminster Press.

Sustainable Energy Forum. (2006). Peak Oil - A Major Issue for New Zealand. Retrieved July 2010, I4, from www.sef.org.nz/papers/peak_oil_info_sheet.pdf

Suzuki, D. T., \& Dressel, H. (2004). From naked ape to superspecies: humanity and the global eco-crisis. Vancouver: Greystone Books.

Telferyoung (Wellington) Limited. (2008). Wellington Office Survey. Wellington: Telferyoung (Wellington) Limited.

Telferyoung Wellington Limited. (2009). Wellington Office Survey - December 2008. Wellington: Telferyoung (Wellington) Limited. 
The Council for Scientific and Industrial Research (CSIR). (2008, May I3). The Sustainable Building Assessment Tool (SBAT). Retrieved August 3, 2010, from CSIR:

www.csir.co.za/Built_environment/Architectural_sciences/sbat.html

The University of Auckland. (2010). Department of Chemical and Materials Engineering. Retrieved March 7, 2009, from The University of Auckland Faculty of Engineering: www.ecm.auckland.ac.nz/uoa/

The World Factbook. (N.d.). Retrieved 05 19, 2010, from Central Intelligence Agency: https://www.cia.gov/library/publications/the-world-factbook/geos/nz.html

Transwestern. (2008). Retrieved August 17, 2010, from The Plaza On K: www.theplazaonk.com U.S Department of Energy. (2009, June 29). Programme Areas. Retrieved August 10, 2010, from Eneegy Efficiency and Renewable Energy: wwwl.eere.energy.gov/femp/program/sustainable_basics.html

U.S. Green Building Council. (20I0). U.S. Green Building Council. Retrieved August 3, 20I0, from U.S. Green Building Council: www.usgbc.org

UNFCCC. (2007). Kyoto Protocol to the United Nations Framework Convention on Climate Change. Retrieved February II, 20I0, from unfccc.int/essential_background/kyoto_protocol/items/I678.php University of Canterbury. (2009). Sustainable Building Design. Retrieved July 21, 2010, from University of Canterbury: www.sustain.canterbury.ac.nz/consenergy/buildings.shtml

Unwin, S. R. (1909, 1994 edition). Town Planning in Practice: An introduction to the art of designing cities and suburbs. New York: Princeton Architcetural Press.

Vale, B. (2010, August 18). Personal Communication.

Vale, B. (2007, March). Sonnenschiff Personal Photograph.

Vale, B., \& Vale, R. (I99I). Towards a Green Architecture. London: RIBA Publications.

Vale, R. (2010, August 26). Personal Communication.

Vavan Vuceljic, S. (2009). Application of smart materials in retrofitting homes can help housing energy efficiency. Belgrade: Union University of Balgrade.

Wackernagel, M., \& Rees, W. (1997). Perpetual and structural barriers to investing in natural capital: economics from an ecological footprint perspective. Ecological Economics, 20(I), Pp. 3-24. 
Wasserman, K. (1976). An Interview with Dr Maria Telkes. Solar Age , PP. I4-I8.

Wellert, E. (2004, August 19). PCM in SmartBoard® MIT Animation Presentation. Germany: BASF.

Whitemyer, D. (2008). The Green Jungle. Perspective , pp. I4-2I.

Whitemyer, D. (2007). The Road to Green. Perspective, pp. 9-I5.

Winstone Wallboards Ltd. (N.d.). Gib Standard. Retrieved August 4, 2010, from Gib:

www.gib.co.nz/gib-standard/

Wood, C. (2006). Walking the Talk: The Sustainable Office Made Easy. Build , Pp. 50-5I.

World Commission on Environment. (1987). Our Common Future. New York: Oxford University Press.

Xenophon. (approx 37I A.D.). The Memorabilia. 


\section{Appendix I: Modelling Data}

Attached are two DVDs containing the full Energy Plus modelling data used for this study and the report of the results compiled by Jessica Bennett. This has been included so that any future study may start where this one has left off. 


\section{Appendix 2: Auckland Residential Model}

Below is the July 2010 draft report of the latest modelling of PCMs in housing undertaken by Department of Chemical and Materials Engineering, University of Auckland (see chapter 3.2). 


\section{Experimental modelling}

The software used in this study is TRNSYS 16.1. TRNSYS is the acronym for TRaNsient SYStems simulation program and has been developed by the University of Wisconsin, United States. This software is used for energy simulations in buildings and analyse the system by using finite difference approaches. The modular structure is its main advantage by giving it more flexibility. The "Multi-Building" Type 56 is used to simulate the thermal behaviour of a building. This Type contains all the information regarding the building: materials, peometry, metoorology, etc.

In order to simulate PCM effects on a building we bave to use a private Type because TRNSYS don't possess a native one to do it. Thus we will use a type developed by F. KUZNIK at the National lnstitute of Applied Sciences of Lyon, France (INSA Lyon). A presentation of his work (mathematical prineiples, work validation) is available in article [6].

We will use a paraffin wax which has numerous advantages as related previously contrary to bydrated salts. A lo of companies commercialize PCM (over 100 PCMs). Nevertheless, among those companies only few of them produce paraffin waxes, the majority commercializes hydrated salts products. PCMs which can be selected for building applications must have their melting temperature around the range $19^{\circ} \mathrm{C}$ to $26^{\circ} \mathrm{C}$. That is why we will use a RT2 material, produced by RUBYTHERM. Moreover the University of Auckland uses this one since severul years and has carried out lot of research on it.

\section{A. Full scale house}

\section{1) Presentation of the house:}

The model used in the simulation aims at representing a usual residential house with regular features and lightweight structure. The house has two single bedrooms, one double bedroom, one bathroom, a kitchen and a living. room in the same area, a corridor and a garage. The total area of the house is $12 \mathrm{~lm}^{2}$, so a common one in New Zealand.

\section{2) Modelling and assumptions:}

The following section present the data used for this simulation.

\section{Geometric model}

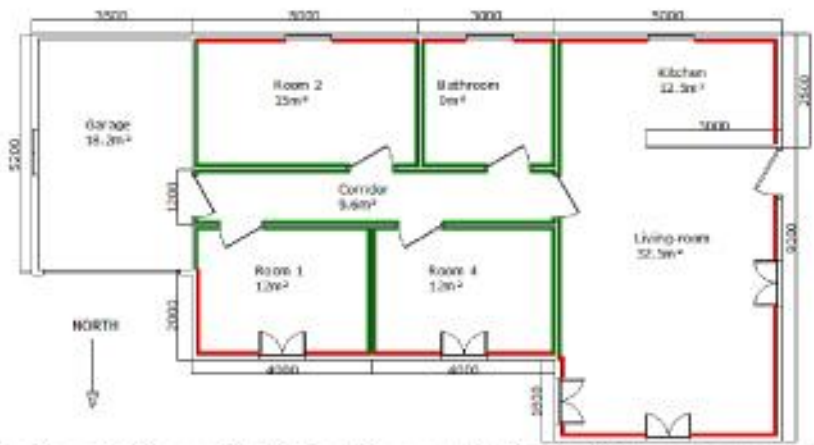

Fig. 1: schematic plan view of the house with PCM location : green for for PCM in internal walls and red in extemal walls

In addition to the schematic plan view of the test room (fig. 3), the following parameters have been used

- Height of the house

- Roof angle:

- Roof space:

$$
\begin{aligned}
& 2.6 \mathrm{~m} \\
& 0^{\circ} \\
& \text { none }
\end{aligned}
$$


Parameters

\begin{tabular}{|c|c|c|c|c|c|c|c|c|}
\hline Name & Layer 1 & Laver ? & Isver 3 & laser 4 & \multirow[b]{2}{*}{ Name } & & & \multirow[b]{2}{*}{$\begin{array}{c}\text { Specific } \\
\text { Heat } \\
\text { (kJ/kg.K }\end{array}$} \\
\hline $\begin{array}{c}\text { External } \\
\text { Walls }\end{array}$ & $\begin{array}{l}\text { Gypsum } \\
(0.013 \mathrm{~m})\end{array}$ & $\begin{array}{l}\text { Insulation } \\
(0.075 \mathrm{~m})\end{array}$ & $\begin{array}{c}\text { Wood } \\
(0.025 \mathrm{~m})\end{array}$ & $\begin{array}{c}\text { Siding } \\
(0.01 \mathrm{~m})\end{array}$ & & $\begin{array}{l}\text { Conductivity } \\
\text { (W/m K) }\end{array}$ & $\begin{array}{l}\text { Density } \\
\left(\mathrm{kg} / \mathrm{m}^{3}\right)\end{array}$ & \\
\hline Internal & Gypsum & Insulation & Gypsum & & Gypsum & 0.25 & 670 & 1.089 \\
\hline Walls & & & {$[0,015 \mathrm{~m}]$} & & Insulation & 0.038 & 32 & 0.835 \\
\hline Roof & $\begin{array}{l}\text { Gypsum } \\
(0.013 \mathrm{~m})\end{array}$ & $\begin{array}{l}\text { Insulation } \\
(0.12 \mathrm{~m})\end{array}$ & $\begin{array}{l}\text { Wood } \\
(0,025 \mathrm{~m})\end{array}$ & $\begin{array}{l}\text { Siding } \\
(0.01 \mathrm{~m})\end{array}$ & Concrete & 1.4 & 2220 & 0.88 \\
\hline Ground & $\begin{array}{l}\text { Concrete } \\
(0.15 \mathrm{~m})\end{array}$ & $\begin{array}{c}\text { Insulation } \\
(0.015 \mathrm{~m})\end{array}$ & & & $\begin{array}{l}\text { Wood } \\
\text { Siding }\end{array}$ & $\frac{0.12}{0.094}$ & $\begin{array}{l}510 \\
640\end{array}$ & $\begin{array}{l}1.38 \\
1.17\end{array}$ \\
\hline
\end{tabular}

Table 1 \& 2: composition of the walls and proprieties of materials

Moreover the followings parameters are used for the modelling:

- Weather data file

- Air infiltrations for all zones :

Auckland airport

- Mechanical ventilation except bathroom: $\quad 0.5 \mathrm{ACH}$

- Mechanical ventilation for bathroom

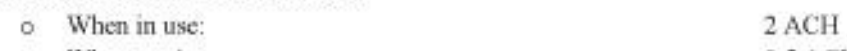

- Heat transfer coefficient (inside): $\quad 3.05 \mathrm{~W} / \mathrm{m}^{2} \cdot \mathrm{K}$

- Heat transfer coefficient (outside): $\quad 17.8 \mathrm{~W} / \mathrm{m}^{2} \cdot \mathrm{K}$

- Solar absomtion (inside): $\quad 60 \%$

- Solar absorption (outside): $\quad 75 \%$

\section{Schotules:}

To be more accurate with reality, schedules are used for lighting, occupancy, heating and cooling set temperature and equipments. The schedules are established on the basis of a family of four persons ( 2 adults and 2 children). To simplify the modelling we will not make differences on the seasons of the year (except of heating and cooling devices). We will only make differences between week and weekend

- Hearing cooling schedule:

- During summer (December to February), the cooling and heating temperatures are respectively set to $22^{\circ} \mathrm{C}$ and $15^{\circ} \mathrm{C}$.

- During the rest of the year, they are respectively set to $25^{\circ} \mathrm{C}$ and $20^{\circ} \mathrm{C}$

Moreover, in the corridor and in the bathroom there is no cooling device, and in garage there are no heating and cooling devices according to regular houses.

- Occupancy schedule Refer to table 8):

Notice: For the corridor and the garage, where the occupancy is very difficult to estimate we will use the following permanent occupancy: 1 person $24 / 24 \mathrm{~h}$ (ISO 7730 seated at rest), scale $1 \%$

- Lighting schedule (Refer to table 9):

Notice: For room 1, room 2, room 4, bathroom and living room we use a $10 \mathrm{~W} / \mathrm{m}^{2}$ lighting power. For the corridor we use a $5 \mathrm{~W} / \mathrm{m}^{2}$ lighting posver. Both have a $10 \%$ convective part (incandescence lamp). There is no lighting in the garage. (*) Only for corridor: $5 \mathrm{~W} / \mathrm{m}^{2}$ for power lighting instead of $10 \mathrm{~W} / \mathrm{m}^{2}$.

- Equipments schedule (Refer to sable 10 \& 11 ):

Notice: (*) fan used only during summer \& (**) fan heater used only during winter

The total convective power is obtained by doing: 


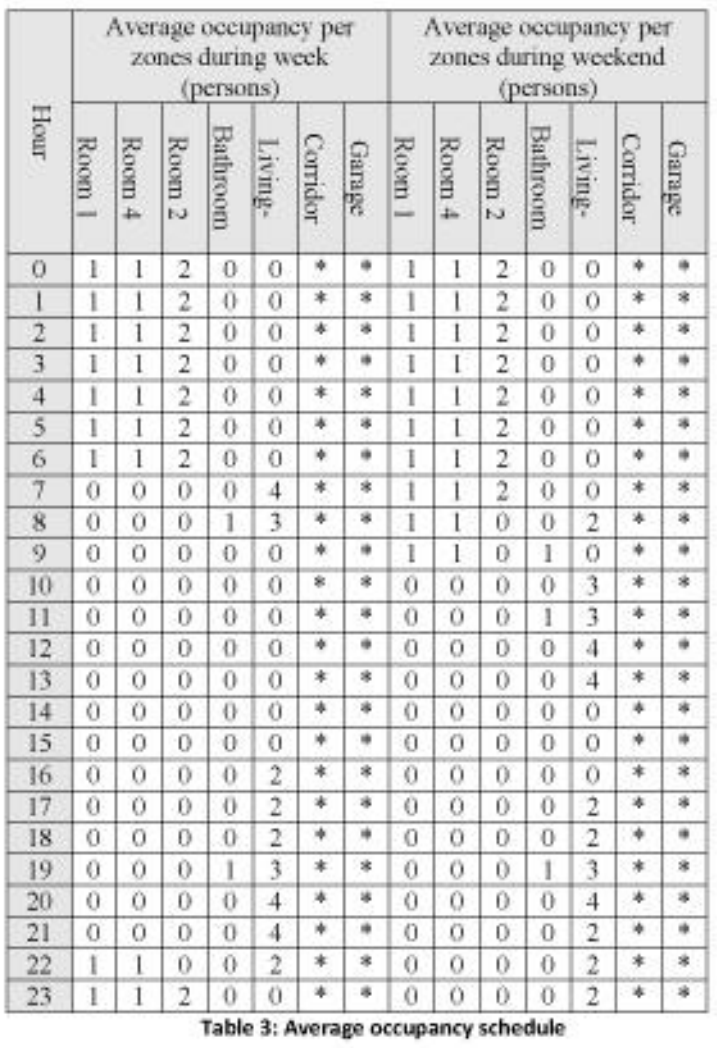

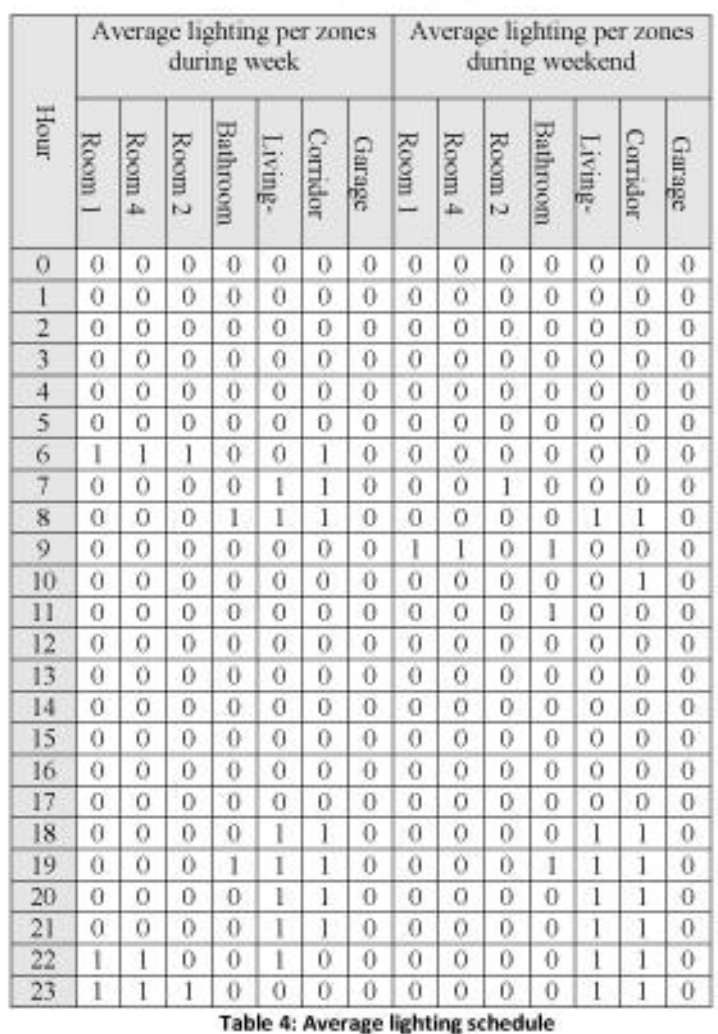

\begin{tabular}{|c|c|c|c|c|c|}
\hline 焉 & Device & Power & Efficiency & $\begin{array}{l}\text { \% use } \\
\text { per } \\
\text { hour }\end{array}$ & $\begin{array}{c}\text { Total } \\
\text { convective } \\
\text { power }\end{array}$ \\
\hline- & - & (Watts) & (\%) & (\%) & (Watts) \\
\hline \multicolumn{6}{|c|}{ Living room } \\
\hline 41 & CD player & 85 & $95 \%$ & $100 \%$ & 4.25 \\
\hline 12 & Computer & 240 & $80 \%$ & $100 \%$ & 48 \\
\hline 13 & Fan $(* *)$ & 50 & $95 \%$ & $100 \%$ & 2.5 \\
\hline LA & Television & 150 & $80 \%$ & $100 \%$ & 30 \\
\hline 15 & Video games & 50 & $80 \%$ & $100 \%$ & 10 \\
\hline \multicolumn{6}{|c|}{ Kitchen } \\
\hline K1 & Coffee maker & 1200 & $75 \%$ & $25 \%$ & 75 \\
\hline K2 & Hot plate & 1200 & $75 \%$ & $100 \%$ & 300 \\
\hline $\mathrm{K} 3$ & Microwave oven & 1450 & $90 \%$ & $25 \%$ & 36.25 \\
\hline K.4 & Toaster & 1145 & $75 \%$ & $25 \%$ & 71.56 \\
\hline KS & Dishwasher & 1200 & $95 \%$ & $100 \%$ & 60 \\
\hline K6 & $\begin{array}{l}\text { Refirigerator } \\
\text { Freezer }\end{array}$ & 420 & $95 \%$ & $100 \%$ & 21 \\
\hline \multicolumn{6}{|c|}{ Garage } \\
\hline G1 & Washer & 1200 & $95 \%$ & $100 \% 6$ & 60 \\
\hline G2 & Dryer & 2790 & $95 \%$ & $100 \%$ & 139.5 \\
\hline \multicolumn{6}{|c|}{ Bathroom } \\
\hline 81 & Fan heater $(* \cdots)\}$ & 600 & $60 \%$ & $50 \%$ & 120 \\
\hline \multicolumn{6}{|c|}{ Bedrooms } \\
\hline R1 & $\begin{array}{l}\text { Sensible gain } \\
\text { room } 1\end{array}$ & - & - & - & 100 \\
\hline 82 & $\begin{array}{l}\text { Sensible gain } \\
\text { room } 2\end{array}$ & - & - & - & 100 \\
\hline R4 & $\begin{array}{l}\text { Sensible gain } \\
\text { room } 3\end{array}$ & - & - & - & 100 \\
\hline
\end{tabular}

Table 5: equipments used by regular families

\begin{tabular}{|c|c|c|c|c|c|c|c|c|}
\hline \multirow[t]{2}{*}{$\frac{T}{0}$} & \multicolumn{4}{|c|}{$\begin{array}{l}\text { Average equipment use during } \\
\text { week }\end{array}$} & \multicolumn{4}{|c|}{$\begin{array}{l}\text { Average equipment use during } \\
\text { weekend }\end{array}$} \\
\hline & $\begin{array}{l}x \\
8 \\
-0 \\
\end{array}$ & $\begin{array}{l}\frac{5}{2} \\
\text { क्. } \\
\frac{1}{8} \\
0 \\
3\end{array}$ & $\begin{array}{l}\text { 崫 } \\
\frac{3}{3} \\
\frac{8}{3} \\
3\end{array}$ & 商 & $\begin{array}{l}x \\
8 \\
\text { 吾 }\end{array}$ & $\begin{array}{l}5 \\
\frac{5}{3} \\
\frac{1}{1} \\
\frac{8}{3} \\
0\end{array}$ & 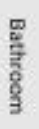 & 飶 \\
\hline $\begin{array}{c}0 \text { to } \\
6\end{array}$ & Ri & К6 & - & - & Ri & K6 & - & - \\
\hline 7 & Ri & $\begin{array}{c}\mathrm{K} 1, \mathrm{~K} 2, \mathrm{~K} 4, \mathrm{~K} 6, \mathrm{~L} \\
1, \mathrm{~L} 2, \mathrm{~L} 4\end{array}$ & - & - & Ri & K6 & - & - \\
\hline 8 & Ri & $K 6, L 2, L 4$ & 81 & - & Ri & $\begin{array}{c}\mathrm{K} 1, \mathrm{~K} 2, \mathrm{~K} 4, \mathrm{~K} 6, \mathrm{~L} \\
1, \mathrm{~L} 2, \mathrm{~L} 4\end{array}$ & - & - \\
\hline 9 & Ri & K6 & - & - & Ri & $K 6, L 1, L 2, L 4$ & B1 & G1 \\
\hline 10 & Ri & K6 & - & - & Ri & $\begin{array}{c}\mathrm{K} 1, \mathrm{~K} 2, \mathrm{KK} 4, \mathrm{~K} 6, \mathrm{~L} \\
1, \mathrm{~L} 2, \mathrm{~L} 4\end{array}$ & - & G2 \\
\hline 11 & Ri & K6 & - & - & Ri & $K 2, K 6, L 2, L 4$ & B1 & - \\
\hline 12 & Ri & K6 & $=$ & - & Ri & $\mathrm{K} 2, \mathrm{~K} 6, \mathrm{~L} 2$ & 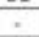 & $=$ \\
\hline 13 & Ri & K6 & - & - & Ri & $\mathrm{K} 6, \mathrm{~L} 2$ & - & - \\
\hline 14 & Ri & K6 & - & - & Ri & K6 & - & - \\
\hline 15 & ค1 & $\mathrm{K} 6$ & - & - & คi & K6 & - & - \\
\hline 16 & $\mathbf{R i}$ & $\begin{array}{c}\mathrm{K} 6, \mathrm{L1}, \mathrm{L}, \mathrm{L}, \mathrm{L}, \mathrm{L} 4 \\
\mathrm{LS}\end{array}$ & - & - & Ri & K6 & - & - \\
\hline 17 & Ri & $\begin{array}{c}\mathrm{K} 6, \mathrm{~L}, \mathrm{~L}, \mathrm{~L}, \mathrm{~L} 13, \mathrm{~L} 4 \\
, \mathrm{~L}, \mathrm{~s}\end{array}$ & . & . & Ri & $\begin{array}{c}\mathrm{K} 6, \mathrm{~L} 1, \mathrm{~L} 2, \mathrm{~L} 3, \mathrm{~L} 4 \\
\mathrm{~L}, \mathrm{~L}\end{array}$ & . & . \\
\hline 18 & Ri & $\begin{array}{c}\mathrm{K} 2, \\
\mathrm{k6}, \mathrm{L} 1, \mathrm{~L} 2, \mathrm{~L}, \mathrm{~L}, \mathrm{L4} \\
\mathrm{LS}\end{array}$ & - & - & Ri & $\begin{array}{c}K 6, L 1, L 2, L 3, L 4 \\
, L 5\end{array}$ & - & - \\
\hline 19 & ตi & $\begin{array}{c}\mathrm{K} 2, \mathrm{~K} 3, \mathrm{~K} 6, \mathrm{~L} 2, \mathrm{~L} \\
3, \mathrm{~L} 4\end{array}$ & 81 & - & คi & $\begin{array}{c}\mathrm{K} 2, \mathrm{~K} 3, \mathrm{~K} 6, \mathrm{~L} 2, \mathrm{~L} \\
3, \mathrm{~L} 4\end{array}$ & B1 & - \\
\hline 20 & Ri & $\mathrm{K} 2, \mathrm{~K} 6,12, \mathrm{~L} 4$ & - & - & Ri & $\mathrm{K} 6, \mathrm{~L} 2$ & - & - \\
\hline 21 & Ri & $\mathrm{K} 5, \mathrm{~K} 6, \mathrm{~L} 2, \mathrm{L4}$ & - & - & Ri & $\mathrm{K} 5, \mathrm{~K} 6, \mathrm{~L} 2, \mathrm{L4}$ & - & - \\
\hline 22 & Ri & $\mathrm{K} 6, \mathrm{~L}, \mathrm{~L}, \mathrm{~L}$ & - & - & Ri & $K 6, L 2, L 4$ & - & - \\
\hline 23 & Ai & $\mathrm{K} 6,12,14$ & - & - & Ri & $\mathrm{K} 6,12,14$ & - & - \\
\hline
\end{tabular}

Table 6: Average equipments use 
[6] Frédéric KUZNIK, Joseph VIRGONE, Kevyn JOHANNES. Development and validation of a new TRNSYS type for the simulation of external building walls containing PCM. Energy and Buildings 42 (2010) 1004-1009. 


\section{Appendix 3: ALF Report}

Below is the ALF report used for confirmation of annual household space heating figures (see chapter 3.2). 


\section{Alf}

BRANZ

\section{ALF Calculation Report}

\section{Project Description}

Project: Residential PCM

Current Design: Auckland Generic House

Date: 03.08.2010

Designed by:

- Address:

- Owner Name

- Street:

- City:

- Phone No.

- Lot No.

- DP No.:

\section{ALF Results Energy}

The results in this section are calculated from the designer inputs including occupancy, and heating temperatures and schedules.

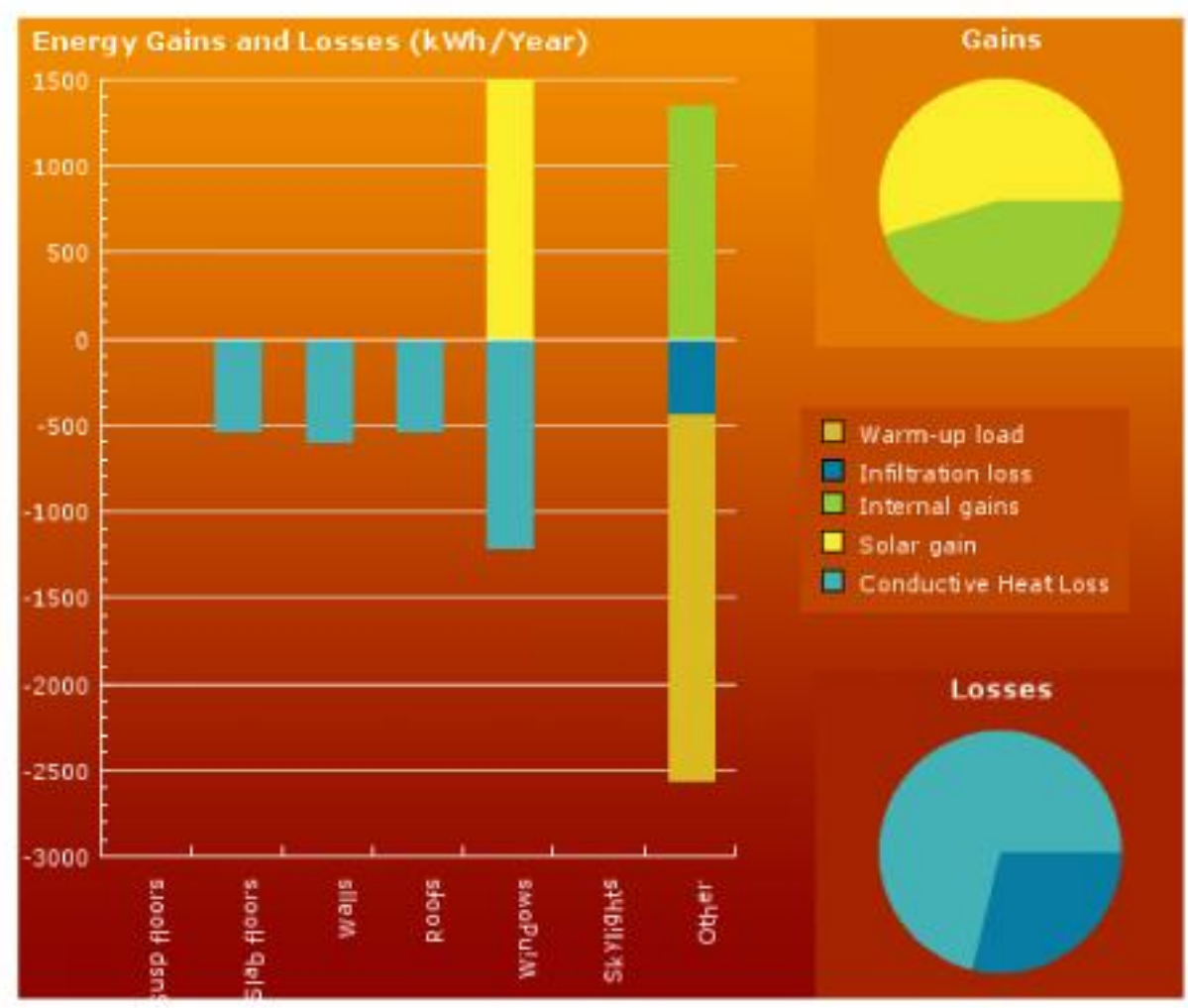




\section{Energy Heat Flows}

The information in the table gives you an overview of all the heat flows in and out of the designed building, based on the heating temperatures, climate and schedule the designer has selected. It allows you to evaluate the importance of the thermal performance of individual building components - for example, of particular windows.

\begin{tabular}{|c|c|c|c|c|c|c|}
\hline & $\begin{array}{c}\text { Net Area } \\
m^{2}\end{array}$ & $\begin{array}{r}\text { Los } \\
\mathrm{kWh} / \text { year }\end{array}$ & $\%$ & $\begin{array}{c}\text { Gain } \\
\text { kWh/year }\end{array}$ & $\%$ & $\begin{array}{l}\text { Useful Gain } \\
\text { kWh/year }\end{array}$ \\
\hline Slab floor & 121 & 535.74 & 9.85 & & & -535.74 \\
\hline \multicolumn{7}{|l|}{ Suspended Floor } \\
\hline Wall $(9 \times 2.6, E)$ & 22.4 & 115 & 2.11 & & & -115 \\
\hline Window $(1 \times 1, E)$ & 1 & 76.67 & 1.41 & 60.99 & 4.07 & $-15,68$ \\
\hline Wall $(16.5 \times 2.6, N)$ & 35.7 & 183.28 & 3.37 & & & -183.28 \\
\hline Window $(1.2 \times 2, N)$ & 2.4 & 184 & 3.38 & 339.58 & 22.64 & 155.58 \\
\hline Window $(1.2 \times 2, N)$ & 2.4 & 184 & 3.38 & 339.58 & 22.64 & 155.58 \\
\hline Window $(1.2 \times 2, N)$ & 2.4 & 184 & 3.38 & 339.58 & 22.64 & 155.58 \\
\hline Wall $(16.5 \times 2.6, \mathrm{~S})$ & 39.3 & 201.76 & 3.71 & & & -201.76 \\
\hline Window $(3.6 \times 1, S)$ & 3.6 & 276 & 5.07 & 137 & 9.14 & -139 \\
\hline Wall $(9 \times 2.6, W)$ & 19.4 & 99.6 & 1.83 & & & -99.6 \\
\hline Window $(2 \times 2, W)$ & 4 & 306.67 & 5.64 & 282.98 & 18.87 & -23.68 \\
\hline Roof $(9 \times 16.5)$ & 148.5 & 533.67 & 9.81 & & & -533.67 \\
\hline Air Leakage & 290.4 & 444.47 & 8.17 & & & \\
\hline Warm-up & & 2113.79 & 38.87 & & & \\
\hline Internal Gain & & & & 1345.1 & 24.73 & \\
\hline
\end{tabular}

- Suspended Floor Loss: TBC kWh/year

- Slab Floor Loss: 535.74 kWh/year

- Wall Loss: $599.64 \mathrm{kWh} /$ year

- Window Loss: $1211.33 \mathrm{kWh} / \mathrm{year}$

- Roof Loss: 533.67 kWhryear

- Skylight Loss: $0 \mathrm{kWh} / \mathrm{year}$

- Air Leakage: $444.47 \mathrm{kWh} / \mathrm{year}$

- Warm-up: $2113.79 \mathrm{kWh} /$ year

- Total Load: $5438.65 \mathrm{kWh} /$ year

- Solar Gain: 1499.71 kWh/year

- Internal Gain: 1345.1 kWh/year (4 occupants)

- Total Gain: 2844.81 kWh/year

- Gain Load Ratio: $52.31 \%$

- Effective Thermal Mass Density (per $\mathrm{m}^{2}$ total floor area): $1.52 \mathrm{~W} / \mathrm{m}^{2}{ }^{\circ} \mathrm{C}$

- Specific Heat Loss Density (per $\mathrm{m}^{2}$ total floor area): $2.39 \mathrm{~W} / \mathrm{m}^{2}{ }^{\circ} \mathrm{C}$

- Usefulness of Gains: $77.41 \%$

- Useful Gains: 2202.19 kWh/year

- Required Heating Energy: 3236.45 kWh/year

\section{NZ Building Code Compliance}

In order to comply with the Energy Efficiency Clause $\mathrm{H} 1$ of the New Zealand Building Code a building has to have a BPI of less than $1.55 \mathrm{kWh} /\left(\mathrm{m}^{2},{ }^{\circ} \mathrm{C}\right.$. month) in any location throughout New Zealand.

The current design's $\mathrm{BPI}$ is: $1.52 \mathrm{H} 1$ pass

The current building design complies with Clause $\mathrm{H} 1$ of the NZBC because it passes the BPI requirements. However, in order to comply with the NZBC it also must comply with Clause $\mathrm{H}_{3}$, Internal Moisture of the NZBC. 
The acceptable solution of Clause E3 of the NZBC requires that R-values for walls, roofs and ceilings shall be no less than:

- For light timber frame wall or other framed wall constructions with cavities, 1.5 .

- For single skin normal weight masonry based wall construction without a cavity, 0.6 .

- For solid timber wall systems no less than $60 \mathrm{~mm}$ thick, 0,6

- For roof and ceilings of any construction, 1.5 .

\section{Modelling Assumptions}

This section lists the modelling assumptions concerning the building design, climate and heating. It defaults to the Building Performance Index assumptions \& requirements as set out in $\mathrm{H} 1$.

\section{Building Design}

\section{General:}

- Total Floor Area: $121 \mathrm{~m}^{2}$

- Number of Occupants: 4 (BPI calculation formula adjusted)

\section{Suspended floor:}

- Floor area: $\mathrm{m}^{2}$

- Perimeter Length: m

- Perimeter Height: m

- Floordeck R-value: $\quad \mathrm{TBC} \mathrm{m}^{20} \mathrm{C} / \mathrm{W}$

- Subfloor R-value: $\quad T B C \mathrm{~m}^{20} \mathrm{CM}$

- Bulk Insulation R-value: $\mathrm{m}^{2 \circ} \mathrm{C} / \mathrm{W}$

- Floor Covering R-value: $\mathrm{m}^{20} \mathrm{C} / \mathrm{W}$

- Total Suspended Floor R-value: $\quad T B C m^{2 \circ} \mathrm{C} / \mathrm{W}$

\section{Slab Floor:}

- Floor Area: $121 \mathrm{~m}^{2}$

- Perimeter Length: $51 \mathrm{~m}$

- External Wall Thickness: $0.12 \mathrm{~m}$

- Soil Conductivity: $1.2 \mathrm{~W} / \mathrm{m}^{\circ} \mathrm{C}$

- Under Floor R-value: $1.32 \mathrm{~m}^{20} \mathrm{C} / \mathrm{W}$

- Slab and Ground R-value: $1.32 \mathrm{~m}^{20} \mathrm{C} / \mathrm{W}$

- Floor Covering R-value:, $4 \mathrm{~m}^{20} \mathrm{CN}$

- Total Slab Floor R-value: $2.6 \mathrm{~m}^{20} \mathrm{C} \mathrm{W}$

Walls:

Bevel-back weatherboard with cavity, $90 \mathrm{~mm}$ frame Studs 600 , dwangs 800 (14\%)

\begin{tabular}{|c|c|c|c|c|c|c|c|}
\hline Name & Orientation & Length & Height & Net Area & $\begin{array}{l}\text { Window } \\
\text { Area }\end{array}$ & $\begin{array}{l}\text { Insulation } \\
\text { R-value }\end{array}$ & $\begin{array}{c}\text { Construction } \\
\text { R-value }\end{array}$ \\
\hline Wall $(9 \times 2.6, E)$ & $E$ & 9 & 2.6 & 22.4 & 1 & 2.4 & 2.24 \\
\hline $\begin{array}{l}\text { Wall }(16.5 \times 2.6 \text {, } \\
\text { N) }\end{array}$ & $\mathrm{N}$ & 16.5 & 2.6 & 35.7 & 72 & 2.4 & 2.24 \\
\hline $\begin{array}{l}\text { Wall }(16.5 \times 2.6 \text {, } \\
\text { S) }\end{array}$ & $\mathrm{s}$ & 16.5 & 2.6 & 39.3 & 3.6 & 2.4 & 2.24 \\
\hline
\end{tabular}



Wall $(9 \times 2.6$,
W
9
2.6
$19.4 \quad 4$
2.4

Roofs:

Pitched profiled metal using $90 \mathrm{~mm}$ joist or bottom chord Joist/chord at $1200(3.75 \%)$

$\begin{array}{clllll}\text { Name } & \text { Length } & \text { Width } & \text { Net Area } & \text { Skylight Area } & \text { Insulation R-value } \\ \text { Roof }(16.5 \times 9) & 16.5 & 9 & 148.5 & 3.2 & 3.2\end{array}$

Windows and skylights:

Aluminium frame

Single clear

Name Wall/Roof Orientation Width Height Net Area Shading R-value SHGC

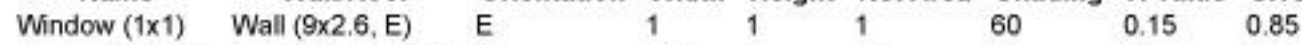

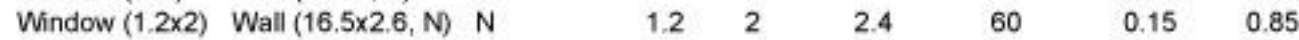

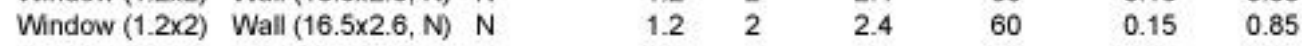

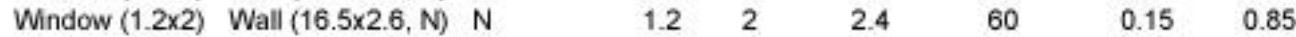

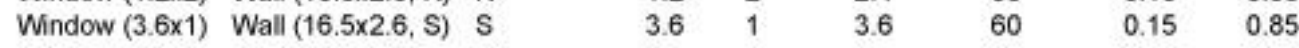

$\begin{array}{lllllllll}\text { Window }(2 \times 2) & \text { Wall }(9 \times 2,6, \mathrm{~W}) & \text { W } & 2 & 2 & 4 & 60 & 0.15 & 0.85\end{array}$

\section{Air Leakage:}

- Basic Airtightness: Airtight - Post 1960 simple shape and single story less than $120 \mathrm{~m}^{2}$

- Chimneys for open fires: None

- No. of flued heaters: None

- Window Passive Vents: None

- Retrofit airtightening: None

- Kitchen vents over hob: Extracting range hood used 1 hour/day

- The location-independent Air Leakage Rate is $1.00 \mathrm{ac} / \mathrm{h}$

- Site Exposure: Semi-exposed - Similar sized buildings or trees on two sides

- Wind Zone Factor: 0.3

- Local Air Leakage Rate: 1.10 ach

- House Volume: $290.4 \mathrm{~m}^{3}$

\section{Thermal Mass:}

\begin{tabular}{lll}
\multicolumn{1}{c}{ Floor type } & Area & Thermal Mass Density \\
Wall - Timber framed & 82.56 & 6.140826446281 \\
Floor - 100mm slab with full insulation & 121 & 56
\end{tabular}

- Total Floor Area (used for Furniture and Ceiling): $121 \mathrm{~m}^{2}$

- Total Thermal Mass: $69.14 \mathrm{kWh} /{ }^{\circ} \mathrm{C}$

- Effective Thermal Mass: $1.52 \mathrm{~W} /{ }^{\circ} \mathrm{C}$

\section{Climate}

- Location: Auckland in the Upper North Island

- Annual Loss Factor. 11.5

- Annual Gain Factors:

N NE E SE S SW W NW H

$\begin{array}{lllllllll}290 & 213 & 124 & 78 & 77 & 79 & 145 & 241 & 204\end{array}$ 
- Internal Gain Multiplier: 1.46

- Wind Zone Factor: 0.3

- NZS 4218:1996 Climate Zone: 1

\section{Heating}

As set by $\mathrm{BPI}$ requirements:

- Heating Schedule: 24 hour heating

- Heating Level: $20^{\circ} \mathrm{C}$

- Calculation Date: 03-08-2010, 11:54AM

This copy of ALF 3.2 is registered to Alice Harland. 


\section{Appendix 4: Data from Portland Cement Association Report}

Data from report (Marceau \& VanGeem, 2007) discussed in chapter 3.4

Table 2. Buildings Modeled

\begin{tabular}{|c|c|c|c|c|}
\hline Designation* & Exterior walls & Structural frame & Floors & Interior walls \\
\hline EL (baseline) & EIFS \& metal stud & structural steel & $\begin{array}{c}\text { concrete on metal } \\
\text { deck }\end{array}$ & metal stud \\
\hline $\mathrm{CL}$ & curtain wall & structural steel & $\begin{array}{c}\text { concrete on metal } \\
\text { deck }\end{array}$ & metal stud \\
\hline $\mathrm{ML}$ & precast concrete & structural steel & $\begin{array}{c}\text { concrete on metal } \\
\text { deck }\end{array}$ & metal stud \\
\hline $\mathrm{EM}$ & EIFS \& metal stud & reinforced concrete & $12^{\prime \prime}$ solid concrete & reinforced concrete \\
\hline $\mathrm{CM}$ & curtain wall & reinforced concrete & $12^{\prime \prime}$ solid concrete & reinforced concrete \\
\hline $\mathrm{MM}$ & $\begin{array}{c}\text { precast concrete } \\
\text { precast concrete } \\
\text { exceeding code }\end{array}$ & reinforced concrete & $12^{\prime \prime}$ solid concrete & reinforced concrete \\
\hline $\mathrm{MLX}$ & $\begin{array}{c}\text { precast concrete } \\
\text { exceeding code }\end{array}$ & reinforced concrete & $12^{\prime \prime}$ solid concrete & reinforced concrete \\
\hline $\mathrm{MMX}$ & $\begin{array}{c}\text { precast concrete } \\
\text { deck }\end{array}$ & reinforced concrete & $12^{\prime \prime}$ solid concrete & reinforced concrete \\
\hline $\mathrm{MMI}$ & $\begin{array}{c}\text { precast concrete } \\
\text { exceeding code }\end{array}$ & reinforced concrete & $12^{\prime \prime}$ solid concrete & reinforced concrete \\
\hline $\mathrm{MMXI}$
\end{tabular}



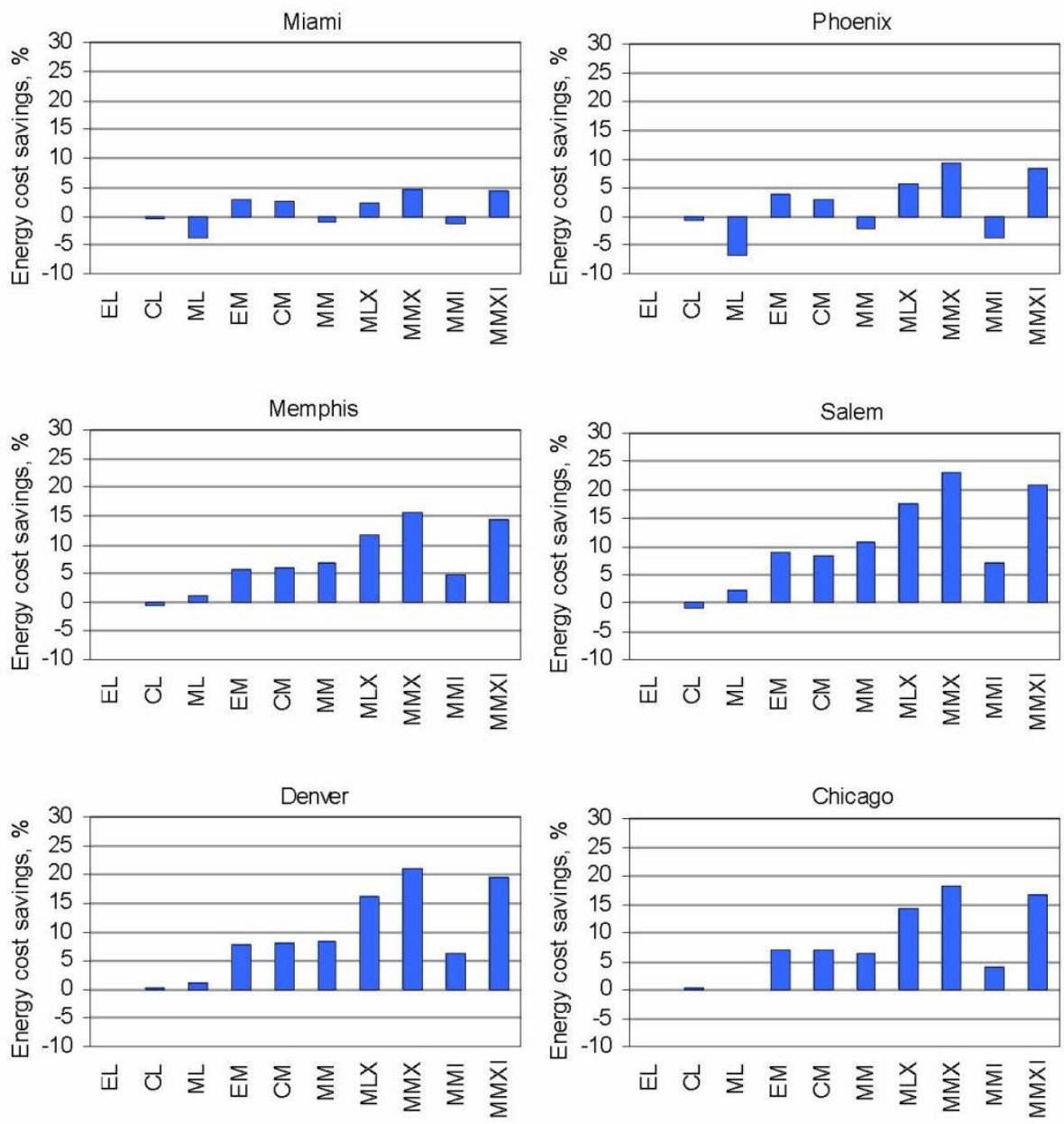

Figure A8. Energy cost savings (from VisualDOE) as a percent of baseline building (EL). The abbreviated scenario names EL through MMXI are described in the text. 